The Geological Society of America

Digital Map and Chart 18

2014

\title{
Geology of the Tierras Blancas area in the southeastern part of the Acambay graben, central Mexico
}

\author{
Lonnie T. Mercer \\ Bart J. Kowallis \\ Eric H. Christiansen \\ Wade E. Miller \\ Department of Geological Sciences, Brigham Young University, Provo, Utah 84602, USA
}

Oscar Carranza-Castañeda

Centro de Geociencias, Campus Juriquilla, Universidad Nacional Autónoma de México, Juriquilla, Querétaro, México, 76230

Isabel Israde-Alcántara

Universidad Michoacana de San Nicolás de Hidalgo, Morelia, Michoacán, Mexico, 58000

\begin{abstract}
Pliocene-Pleistocene sediments in the southeastern Acambay graben, central Mexico have yielded mammal fossils, including Equus simplicidens, cf. Rhynchotherium, ?Camelops, Mammuthus sp., Bison sp., and Antilocapra sp. The fossiliferous sediments include layers of lacustrine deposits from the late Pliocene-early Pleistocene in between layers of fluvial and alluvial deposits from the early Pliocene and Pleistocene. The sediments deposited in this late Pliocene paleolake record a history of lake level fluctuations, shown by lithologic variations in lacustrine sediments and abundance of vertebrate burrows.

Volcanic and tectonic events in the Acambay graben were the major controls on sedimentation during Pliocene-Pleistocene time. Local volcanic structures were sources of the Pliocene-Pleistocene sediments, and intra-arc extensional tectonics caused basin subsidence. Blockage of stream drainages by lava flows or perhaps increased basin subsidence contributed to the appearance of and fluctuations in the lacustrine system during the late Pliocene. Diatom assemblages from these lacustrine sediments indicate slightly higher precipitation and humidity during the late Pliocene than present-day conditions in the Acambay graben. Therefore, climatic forcing may have also contributed to the development of the late Pliocene paleolake in the Acambay graben.

Pliocene-Pleistocene volcanic rocks in this part of the Acambay graben range from basaltic andesite to rhyolite. The calc-alkaline composition of these volcanic rocks is similar to others in the modern Mexican Volcanic Belt consistent with their tectonic setting. The major eruptive episode in the Acambay graben began in the
\end{abstract}

Mercer, L.T., Kowallis, B.J., Christiansen, E.H., Miller, W.E., Carranza-Castañeda, O., and Israde-Alcántara, I., 2014, Geological Society of America Digital Map and Chart 18, 46 p., doi:10.1130/2014.DMCH018. For permission to copy, contact editing@ geosociety.org. @ 2014 The Geological Society of America. All rights reserved. 
early Pliocene, but volcanism, represented by small volcanic vents and lava flows, continued until the late Pleistocene. Extension appears to have been most active at this time as well. The decline in volcanism in the Acambay graben correlates with an early Pliocene through Quaternary trenchward migration of volcanism in the TransMexican Volcanic Belt. Early Pliocene sediments (the Lagunita beds) are dominated by volcanic clasts derived from Cerro San Pedro stratovolcano that was active at this time. The sediments also include distal fallout tuffs with distinctive peralkaline compositions. Lithic clasts in the late Pliocene-Pleistocene sediments (the Tierras Blancas and Cementerio beds) come from local (magnesian dacite and rhyolite) as well as distal (ferroan trachydacite and latite) sources. The earliest local volcanism (Miocene-Pliocene) is represented by medium- $\mathrm{K}_{2} \mathrm{O}$ dacite with large enrichments of fluid-soluble elements that probably formed at the volcanic front. During slab roll back, the volcanic front moved to its present position $\sim 100 \mathrm{~km}$ to the south. In the back arc, extension, related to slab roll back and enhanced corner flow, formed the Acambay graben and allowed Quaternary magmas dominantly formed by decompression melting (high- $\mathrm{TiO}_{2}$, medium- $\mathrm{K}_{2} \mathrm{O}$ basaltic andesite) to erupt as scoria cones and small lava flows. Quaternary high- $\mathrm{K}_{2} \mathrm{O}$ andesites formed by mixing a silicic component, formed by partial melting of the crust, with the hot high- $\mathrm{TiO}_{2}$ basaltic andesites. The mineralogy and geochemistry of these back-arc back arc magmas show they were not as wet as those closer to the arc front.

\section{INTRODUCTION}

Late Cenozoic sediments of the Tierras Blancas area lie along the southeastern margin of the Acambay graben, central Mexico (Fig. 1), 5-10 km north of Atlacomulco. These sediments have yielded mammal fossils that have contributed to an important and growing collection of late Cenozoic mammal fossils from across central Mexico. This collection has enhanced our understanding of the Great American Biotic Interchange by constraining the timing of the appearance of South American immigrants in North America (Miller and Carranza-Castañeda, 1984, 2001; Carranza-Castañeda and Miller, 1996; Kowallis et al., 1998; Flynn et al., 2005; Adams et al., 2006). Geologic mapping of the Tierras Blancas area supplies a framework for evaluation of the fossiliferous sediments. In addition, a newly established stratigraphic framework for this area provides constraints on the ages of previously unstudied sedimentary and volcanic rocks. Changes in the character of these late Cenozoic sedimentary and volcanic rocks give evidence of climatic, tectonic, and volcanic variations in the Acambay graben during PliocenePleistocene time.

\section{Late Cenozoic Mammalian Biostratigraphy of Central Mexico}

North American mammalian fossils are valuable in the biochronology of nonmarine sediments, and they provide the database for understanding Late Cenozoic mammal dispersal events in North America (e.g., Lindsay et al., 1984; Webb, 1991; Webb and Opdyke, 1995). Central Mexico lies in an excellent location for deciphering the timing of the immigration of South American mammals into North America after the formation of the
Panamanian land bridge (Miller and Carranza-Castañeda, 2001). Late Cenozoic sediments in small basins of central Mexico (Fig. 2) have also yielded vertebrate fossils that have significantly improved late Cenozoic mammalian biostratigraphy of North America by constraining the age of the Hemphillian-Blancan boundary at $\sim 4.8 \mathrm{Ma}$ (Miller, 1980; Miller and CarranzaCastañeda, 1982, 1984, 1996, 2001; Carranza-Castañeda and Miller, 1988, 1996; Montellano-Ballesteros, 1992; Kowallis et al., 1998; Lindsay et al., 2002).

Layers of glassy volcanic ash are often found interbedded with the fossiliferous sediments and provide radiometric ages that improve chronologic control. Recent studies of the fossils, sediments, and volcanic ash beds of these basins have provided better timing on initiation of the Great American Biotic Interchange during the latest Hemphillian and earliest Blancan in central Mexico (Miller and Carranza-Castañeda, 1984, 2001; Carranza-Castañeda and Miller, 1996; Kowallis et al., 1998; Flynn et al., 2005; Adams et al., 2006). Data from these basins suggest "a much more staggered, variable arrival and dispersal of individual South American immigrants" starting by at least 4.7-4.8 Ma (Flynn et al., 2005). See Campbell et al. (2010) for another view on timing of the interchange.

Previous studies have focused on the sedimentary basins in the states of Baja California, Hidalgo, Guanajuato, and Jalisco (Miller, 1980; Miller and Carranza-Castañeda, 1982, 1984, 1996, 2001; Carranza-Castañeda and Miller, 1988, 1996). This study concentrates on the Acambay graben, which lies in the states of Mexico and Michoacán that has not been studied in detail before (Fig. 2).

Our goal was to map the southeastern part of the Acambay graben where Late Cenozoic fossil-bearing sedimentary rocks are found, examine these strata for fossils and place the fossils in 

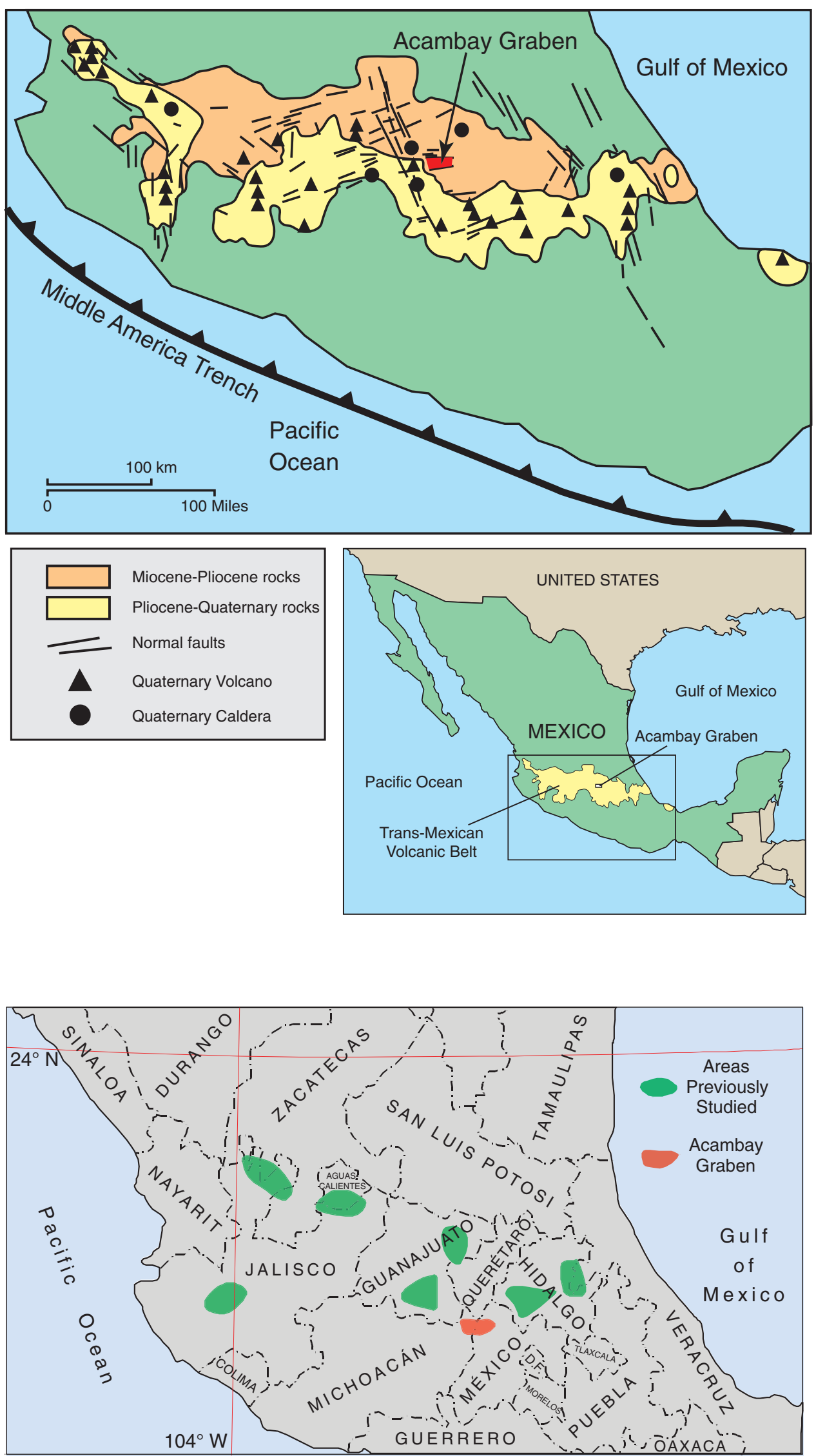

Figure 1. Index map of major volcanoes, calderas, and fault systems in the Mexican Volcanic Belt. The Acambay graben is in the central portion of the Mexican Volcanic Belt and forms the eastern part of the east-west trending Chapala-Tula fault system. Inset shows regional map of the Mexican Volcanic Belt. Modified after Aguirre-Díaz and McDowell (2000).

Figure 2. Map of central Mexico showing Late Cenozoic basins that yield mammal fossils. Green-colored basins have been previously studied (Miller, 1980; Miller and Carranza-Castañeda, 1982, 1984, 1996, 2001; CarranzaCastañeda and Miller, 1988, 1996; Montellano-Ballesteros, 1992; Kowallis et al., 1998; Lindsay et al., 2002). The red area marks the Acambay graben along the border of the states of México and Michoacán. 
a solid stratigraphic context. In addition, we have characterized the tectonic history and the associated volcanic rocks, their compositions, and ages to better understand their origin and history.

\section{Regional Geology}

The Trans-Mexican Volcanic Belt extends over $1000 \mathrm{~km}$ along an east-west trend across central Mexico (Fig. 1; Nixon, 1982; Verma, 1987; Suter et al., 1995; Sheth et al., 2000; García-Palomo et al., 2002). Volcanic rocks of the modern TransMexican Volcanic Belt are predominantly medium- to high-K and calc-alkaline (magnesian, in the sense of Frost et al., 2001), although intraplate alkaline rocks locally comprise a significant volume of the Trans-Mexican Volcanic Belt (Nixon, 1982; Nixon et al., 1987; Verma, 1987; Moore et al., 1994; Márquez et al., 1999; Sheth et al., 2000). The coexistence of calc-alkaline and intraplate alkaline volcanism in central Mexico has created considerable controversy, but the most workers attribute the majority of the volcanism to subduction of the Cocos and Rivera Plates beneath the North American Plate along the Middle American
Trench (Nixon, 1982; Nixon et al., 1987; Verma, 1987; Moore et al., 1994; Márquez et al., 1999; Sheth et al., 2000; Ferrari et al., 2001). The present-day plate tectonic configuration of the Cocos and Rivera Plates dates back to the late Miocene (Nixon, 1982; Verma, 1987; Bandy et al., 2000). The onset of volcanism in the Trans-Mexican Volcanic Belt initiated in the middle to late Miocene (Nixon et al., 1987; Ferrari et al., 1999; Márquez et al., 1999; Sheth et al., 2000; García-Palomo et al., 2002), and a trenchward migration of volcanism occurred from the late Miocene-early Pliocene to the early Quaternary (Nixon et al., 1987; Ferrari et al., 1999; Fig. 1).

Within the Trans-Mexican Volcanic Belt, there are a series of east-west-trending tectonic depressions that comprise the ChapalaTula fault zone (Fig. 1; Johnson and Harrison, 1990; Suter et al., 1995). These tectonic basins are the result of intra-arc extension within the Trans-Mexican Volcanic Belt that began in the late Miocene (Suter et al., 1995; Campos-Enriquez et al., 2000; Suter et al., 2001). The Acambay graben (Fig. 3) lies in the eastern sector of the Chapala-Tula fault zone and is bounded by the AcambayTixmadejé and Pastores faults on the north and south, respectively

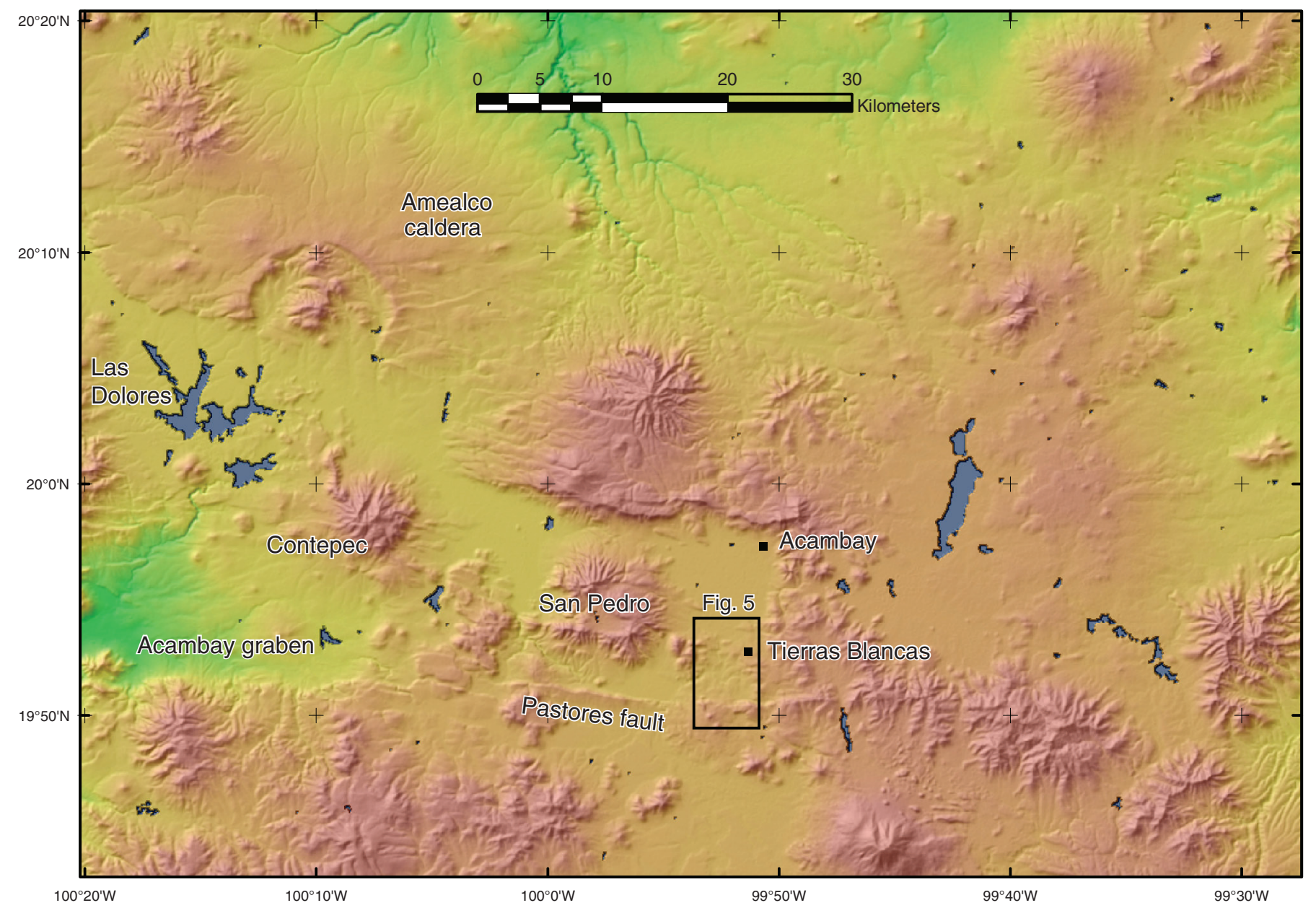

Figure 3. Digital relief map of central Mexico showing the location of the study area (Fig. 5) and a few of the major volcanic and structural features of the area. 
(Johnson and Harrison, 1990; Suter et al., 1995; Suter et al., 2001). Central Mexico also lies at the southern intersection of the Basin and Range province, and the Trans-Mexican Volcanic Belt is superposed on the preexisting structural fabric of Basin and Range extension (Henry and Aranda-Gomez, 1992).

Late Cenozoic lacustrine systems developed within the intraarc basins of the Trans-Mexican Volcanic Belt (Chacón-Torres and Múzquiz-Iribe, 1997; Israde-Alcántara, 1997; Metcalfe, 1997; Rosas-Elguera and Urrutia-Fucugauchi, 1998; Israde-Alcántara and Garduño-Monroy, 1999; Michaud et al., 2000; Suter et al., 2001; Israde-Alcántara et al., 2010). Some of the lakes have persisted to the present, such as Lake Cuitzeo (Israde-Alcántara and Garduño-Monroy, 1999; Israde-Alcántara et al., 2010), Lake Chapala (Rosas-Elguera and Urrutia-Fucugauchi, 1998; Michaud et al., 2000), and Lake Pátzcuaro (Chacón-Torres and Múzquiz-Iribe, 1997; Bradbury, 2000), while several other lake systems disappeared (Chacón-Torres and Múzquiz-Iribe, 1997; Israde-Alcántara, 1997; Rosas-Elguera and Urrutia-Fucugauchi, 1998; Israde-Alcántara and Garduño-Monroy, 1999; Michaud et al., 2000; Israde-Alcántara et al., 2010).

\section{Previous Work in the Acambay Region}

The stratigraphy and structure within the Acambay graben have not been extensively studied (Suter et al., 1995; AguirreDíaz et al., 2000) partly due to limited exposures. Aguirre-Díaz et al. (2000) summarized the stratigraphy of the north and south walls of the graben (Fig. 4). The oldest units are Mesozoic metasedimentary rocks cut in places by mafic and felsic dikes, which have been reported to crop out in a few locations along the southern margin of the graben (Norato-Cortez, 1998; AguirreDíaz et al., 2000). These are overlain by intermediate composition Miocene to Pliocene volcanic rocks. One of the dominant units in this interval is the Pliocene Amealco Formation composed of ignimbrites and tephras erupted from the Amealco Caldera. Overlying the Amealco Formation are Plio-Pleistocene lacustrine sediments and Pleistocene to Recent mafic and intermediate lava flows. Suter et al. (1995) determined an age of 0.4 Ma for a "basaltic" lava flow (identified below as andesitic) associated with scoria cones northwest of Atlacomulco, but most of these younger lava flows have not been dated.

These lava flows cover the Pastores fault and extend northward into the study area. Suter et al. (1995) reported an outcrop that exposes the Pastores fault cutting these lava flows, but this relationship is obscured in most locations due to poor exposure of fault scarps. Several stratovolcanoes, lava domes, and cinder cones with associated lava flows have erupted within the graben (Norato-Cortez, 1998; Ramírez-Herrera, 1998).

The Pliocene-Pleistocene fluvial, alluvial, and lacustrine sediments found within the Acambay graben have not previously been studied in detail. The lake deposits have been attributed to tectonic depressions (sag ponds) that formed along the Pastores fault (Suter et al., 1995; Aguirre-Díaz et al., 2000). Suter et al. (1995) and Aguirre-Díaz et al. (2000) referred to lacustrine sedi- ments that crop out along the Pastores fault, both in the footwall and hanging wall, and they indicated a correlation of all of these lake sediments with the Ixtapantongo Formation of SánchezRubio (1984). While lacustrine sediments in the footwall of the Pastores fault may correlate with the Quaternary Ixtapantongo Formation (radiocarbon age of $23 \mathrm{ka}$; Sánchez-Rubio, 1984), lacustrine deposits in the hanging wall of the Pastores fault, lying in this study area, cannot be correlative to the Ixtapantongo Formation because they lie stratigraphically below Quaternary lava flows mentioned above and dated at 0.4 Ma (Suter et al., 1995).

The lake sediments within the Acambay graben contain Blancan vertebrate fossils from the latest Pliocene and earliest

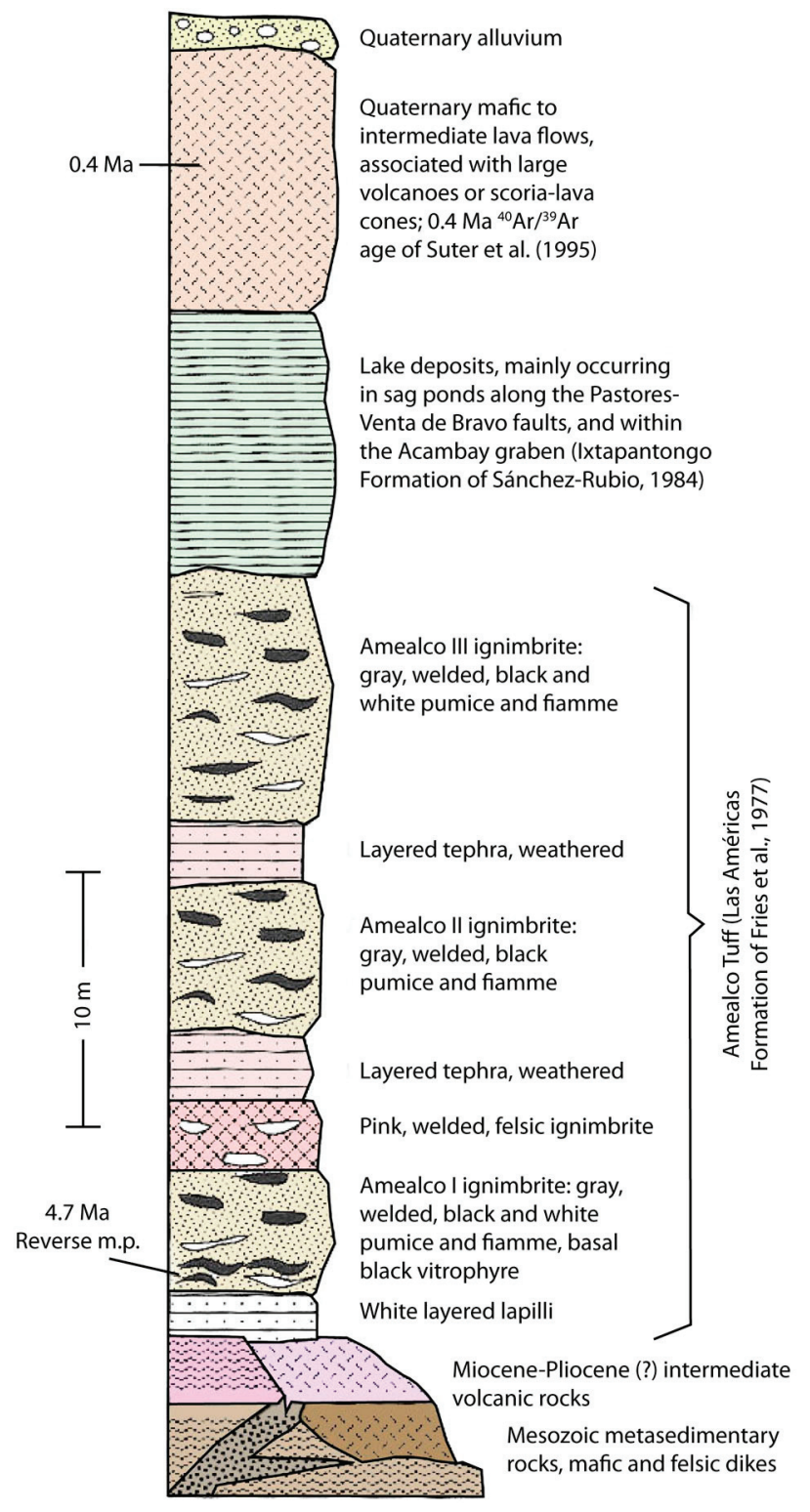

Figure 4. Stratigraphy of the southern sector of the Acambay Graben modified from Aguirre-Díaz et al. (2000). The focus of this study is the rocks overlying the Amealco Tuff. 
Mercer et al.

Pleistocene as determined by the presence of Equus simplicidens (Woodburne, 2004). Identified Blancan vertebrate faunas from the Acambay graben include horses, mastodons, and camels (Mercer et al., 2002). In addition, horse, camel, mammoth, bison, and antilocaprid fossils have been recovered from Quaternary sediments in the graben.

One volcanic ash layer has been found interbedded with lake sediments near the top of the stratigraphic section. Zircons separated from the ash layer were dated by standard fission-track methods and gave an age of $1.20 \pm 0.13 \mathrm{Ma}$ (Mercer et al., 2002).

\section{METHODS}

\section{Geologic Map and Stratigraphic Descriptions}

Geologic mapping was completed for a 7.6 by $5.3 \mathrm{~km}$ area in the southeastern sector of the Acambay graben (Fig. 5). The geologic map was completed on aerial photographs in the field and then transferred to a 1:50,000 topographic base map using Adobe Illustrator ${ }^{\mathrm{TM}}$

Stratigraphic sections were measured, described, and photographed in nine localities throughout the area using a tape and $35-\mathrm{mm}$ camera. Section locations were selected in order to provide complete geographic coverage of the fossiliferous lacustrine sediments and proximity to fossil localities. Samples, including volcaniclastic sandstones, mudstones, and volcanic ashes, were collected from each measured section (Table 1A). The sedimentary units were described and photographed in several other locations. Bedding and fault plane attitudes were measured with a Brunton compass and plotted on equal-area stereoplots (using RockWorks ${ }^{\mathrm{TM}}$ ) to characterize structural patterns. Sample and section locations were collected using a Garmin eTrex GPS unit.

Vertebrate localities were photographed, and fossils were collected using standard vertebrate fossil collecting techniques. Specimens collected were prepared and placed in the collections at the Universidad Nacional Autónoma de México.

\section{Sandstone Petrography and Modal Analysis}

Eleven medium- to coarse-grained sandstone samples and four sandy mudstone samples were selected for thin-section preparation and modal analysis. Samples were selected from nearly every measured section in order to account for variations in sandstone petrography throughout the area. Samples were impregnated with epoxy and cut into standard thin sections (prepared by Wagner Petrographic, Provo, Utah). Point counts were accomplished using a petrographic microscope equipped with an automated stage. Three hundred points were counted for each sample using the Gazzi-Dickinson method (Dickinson, 1970; Ingersoll et al., 1984; Ingersoll and Cavazza, 1991). Counted grain types include monocrystalline quartz, plagioclase feldspar, potassium feldspar, opaque minerals, miscellaneous minerals, and volcanic lithic fragments (Dickinson, 1970; Ingersoll et al., 1984). Volcanic lithic grains were counted according to the following textures: vitric, lathwork, microlitic, granular, and seriate (Dickinson, 1970; Ingersoll and Cavazza, 1991; Critelli et al., 2002).

\section{Volcanic Lithic Grain Chemistry}

Four of the petrographically analyzed sandstone samples (AG-03-01, AG-06-01, AG-08-01, and AG-04-04) were prepared as polished thin sections for electron microprobe analysis in order to analyze the composition of volcanic lithic grains. Ten to twenty grains were analyzed from each thin section at Brigham Young University with a Cameca SX-50 electron microprobe.

Vitric grain analyses used a $10-\mu$ beam with a $15 \mathrm{kV}$ accelerating voltage, $10 \mathrm{nA}$ beam current, and 20 -second counting times to minimize volatilization of $\mathrm{Na}$. Ten non-vitric grains with lathwork and microlitic textures were also analyzed in one thin section (AG-04-04), which contains a significant portion of these grain types, using a 50- $\mu$ beam. Analyzed elements include $\mathrm{Si}, \mathrm{Ti}$, $\mathrm{Al}, \mathrm{Fe}, \mathrm{Mn}, \mathrm{Mg}, \mathrm{Ca}, \mathrm{Na}, \mathrm{K}$, and Ba. Rhyolitic glass from Yellowstone National Park, Wyoming and hornblende from Kakanui, New Zealand were used as standards for calibration. (Complete data tables available through the electronic thesis/dissertation repository of the Harold B. Lee Library at Brigham Young University, http://etd.byu.edu/.)

\section{Volcanic Rock Analyses}

Approximately 25 whole-rock samples of the volcanic units were collected throughout the area (Fig. 5). Rock chips were powdered in a tungsten carbide shatter box in preparation for $\mathrm{X}$-ray fluorescence analysis.

Samples of volcanic ash layers were collected in five localities (Fig. 5). These samples were prepared for X-ray fluorescence analysis following the methods of Perkins et al. (1995). They were washed repeatedly in water to remove organic material and clay. After drying overnight, each sample was sieved through 18 , $35,60,120$, and 230 size brass sieves. A glass fraction of $>99.5 \%$ purity was prepared from the 60-120 fraction by acid washing to remove carbonate minerals and surficial clay alteration in $10 \%$ $\mathrm{HNO}_{3}$ for 15 min and then washed repeatedly in deionized water. Next, the samples were treated with a 5\% HF solution in an ultrasonic cleaner, washed repeatedly in deionized water, and then quickly dried using acetone. After cleaning, a Frantz Isodynamic Separator ${ }^{\mathrm{TM}}$ was used to remove magnetic and nonmagnetic minerals from the glass fraction. Each glass fraction was checked for purity using a petrographic microscope. Glass fractions of each sample were powdered in a tungsten carbide shatter box.

Glass disks were formed by fusion of $1.00 \mathrm{~g}$ of rock powder, $7.00 \mathrm{~g}$ of a 50/50 mixture of lithium tetraborate and lithium metaborate, $0.03 \mathrm{~g}$ of cesium iodide, and $0.03 \mathrm{~g}$ of lithium nitrate for major element analysis (Table 1B). Loss on ignition was measured by heating $\sim 2.0 \mathrm{~g}$ of rock powder at $1000{ }^{\circ} \mathrm{C}$ in an oven for $4 \mathrm{~h}$. Two grams of rock powder was pressed into $3.2 \mathrm{~cm}$ diameter pellets backed by Whatman fibrous cellulose for trace element 
analysis (Table 1C). X-ray fluorescence analysis was completed at Brigham Young University using a Siemens SRS-303 wavelength dispersive spectrometer.

International reference standards (QLO-1 and JB-2) were analyzed as unknowns to assess accuracy. Analyzed trace elements include $\mathrm{Sc}, \mathrm{V}, \mathrm{Cr}, \mathrm{Ni}, \mathrm{Cu}, \mathrm{Zn}, \mathrm{Ga}, \mathrm{Rb}, \mathrm{Sr}, \mathrm{Y}, \mathrm{Zr}, \mathrm{Nb}, \mathrm{Ba}, \mathrm{La}$, $\mathrm{Ce}, \mathrm{Nd}, \mathrm{Sm}, \mathrm{Pb}$, Th, and $\mathrm{U}$.

\section{Diatom Analysis}

Twenty-nine samples from lacustrine sediments were collected in $\sim 0.3 \mathrm{~m}$ intervals at the Los Espejos locality (Fig. 5) for diatom analysis. Diatoms from these samples, along with an additional nine lacustrine samples from other localities, were prepared using the method of Scherer (1994) to clean and separate the diatom valves from the sediment and organic material. Deionized water was used to wet and break up $\sim 0.5 \mathrm{~cm}^{3}$ of each sediment sample in a 400-ml Pyrex beaker. After breaking up the sediment, $20 \mathrm{~cm}^{3}$ of $30 \% \mathrm{H}_{2} \mathrm{O}_{2}$ was added. The mixture was heated and boiled at $\sim 150{ }^{\circ} \mathrm{C}$ for $30 \mathrm{~min}$. Twenty $\mathrm{cm}^{3}$ of $\mathrm{HNO}_{3}$ was then added, and the mixture was boiled for another $30 \mathrm{~min}$. The mixture was removed from the heat and let stand for $60 \mathrm{~min}$. The beaker was filled with deionized water and let stand for $6 \mathrm{~h}$. The water was then decanted, and the process of washing with deionized water was repeated until the solution was no longer cloudy.

To prepare slides for diatom identification, a standardized aliquot (3:1) of diatoms suspended in water was settled onto cover slips. Clean slides were placed on a metal plate heated by a hot plate to over $100{ }^{\circ} \mathrm{C}$. A Pasteur pipette was used to place Naphrax ${ }^{\mathrm{TM}}$, a refractive medium, in the center of each slide to cover an area the size of a cover slip. When the Naphrax ${ }^{\mathrm{TM}}$ began to bubble less vigorously, the sediment-laced cover slips were placed sediment-side down on each slide to cover the Naphrax ${ }^{\mathrm{TM}}$. The slides were then removed from the hot plate, cooled, and labeled. Diatom valves were identified using optical microscopy.

\section{Mammal Fossils and Leaf Imprints}

Mammal fossils were collected for curation by Dr. Oscar Carranza (Universidad Nacional Autónoma de México). Most of the fossils reside in a collection of the Universidad Nacional Autónoma de México (Mexico City). Leaf imprints in the lake sediments were sampled in two localities. The most complete leaf imprints were identified by Dr. Sergio Cevallos-Ferriz (Universidad Nacional Autónoma de México) and now reside in the collection there. In addition, several collected leaf imprints are stored at Brigham Young University (Provo, Utah).

\section{STRATIGRAPHY}

The stratigraphy of the southeastern part of the Acambay graben includes Mesozoic basement rocks, late Tertiary-Quaternary volcanic rocks, and Pliocene-Pleistocene fluvial, alluvial, and lacustrine sediments (Fig. 6).

\section{Mesozoic}

\section{Mesozoic Tlalpujahua Metamorphic-Plutonic Complex}

The oldest rocks exposed along the southern flank of the Acambay graben are a sequence of slates and slightly metamorphosed shales. These metasedimentary rocks crop out in the footwall of the south-central sector of the Acambay graben and are cut by intermediate to silicic dikes and sills observed inside mines near Tlalpujahua village (Aguirre-Díaz et al., 2000) $\sim 30 \mathrm{~km}$ WSW of the study area. The Tlalpujahua metamorphicplutonic complex has an inferred Mesozoic age, based on lithologic similarities to regional sedimentary rocks (Aguirre-Díaz et al., 2000).

\section{Cenozoic}

\section{Miocene-Pliocene Volcanic Rocks (Tv)}

The footwall of the Pastores fault in the study area exposes at least $300 \mathrm{~m}$ of undated intermediate to silicic volcanic rocks (Figs. 5 and 6). Near Tlalpujahua, these volcanic rocks unconformably overlie the Tlalpujahua metasedimentary rocks but are not cut by plutonic rocks, suggesting a Miocene-Pliocene age (Aguirre-Díaz et al., 2000). A low-silica dacite (Fig. 7; Curva in Tables $1 \mathrm{~A}-1 \mathrm{C}$ ) was sampled from the undifferentiated units in the footwall of the Pastores fault (Fig. 5). It has a light tan to light gray groundmass and lacks phenocrysts. Unlike most of the other intermediate composition lavas in this area, this dacite is ferroan and medium- $\mathrm{K}_{2} \mathrm{O}$ rather than high- $\mathrm{K}_{2} \mathrm{O}$ (Fig. 7). It has the typical spikey trace element pattern of a subduction-related magma with a large negative $\mathrm{Nb}$ and $\mathrm{Ti}$ anomaly, and enrichments in $\mathrm{K}, \mathrm{Rb}$, $\mathrm{Ba}$, and $\mathrm{Pb}$ (Figs. 8 and 9). In addition, its ferroan character and high $\mathrm{CaO}$ concentrations are unlike most of the other lavas in the area. However, it may be like the medium- $\mathrm{K}_{2} \mathrm{O}$ series described by Blatter et al. (2007) in this area of central Mexico.

\section{Early-Middle Pliocene Lagunita Beds (Tl)}

The Lagunita beds are the basal stratigraphic unit exposed in the graben and generally show $2-5 \mathrm{~m}$ of exposure, except in the northeastern part of the field area where $\sim 30 \mathrm{~m}$ of Lagunita beds are exposed (Fig. 10). The Lagunita beds (Fig. 6) consist of five lithofacies: (1) tuffaceous mudstone, (2) volcaniclastic sandstone, (3) lapilli ash-flow tuff, (4) fallout tuff, and (5) volcanic breccia (debris flow/lahar).

Mammal fossils are sparse in the Lagunita beds, as only two horse teeth have been found in volcaniclastic sediments. Radiometric ages have not been determined for volcanic rocks in the Lagunita beds, but Blancan Equus simplicidens fossil teeth constrain the age of deposition to the Pliocene. In addition, an angular unconformity between the Lagunita beds and the overlying late Pliocene-early Pleistocene Tierras Blancas beds (Fig. 11) indicates a probable early Pliocene age for the 


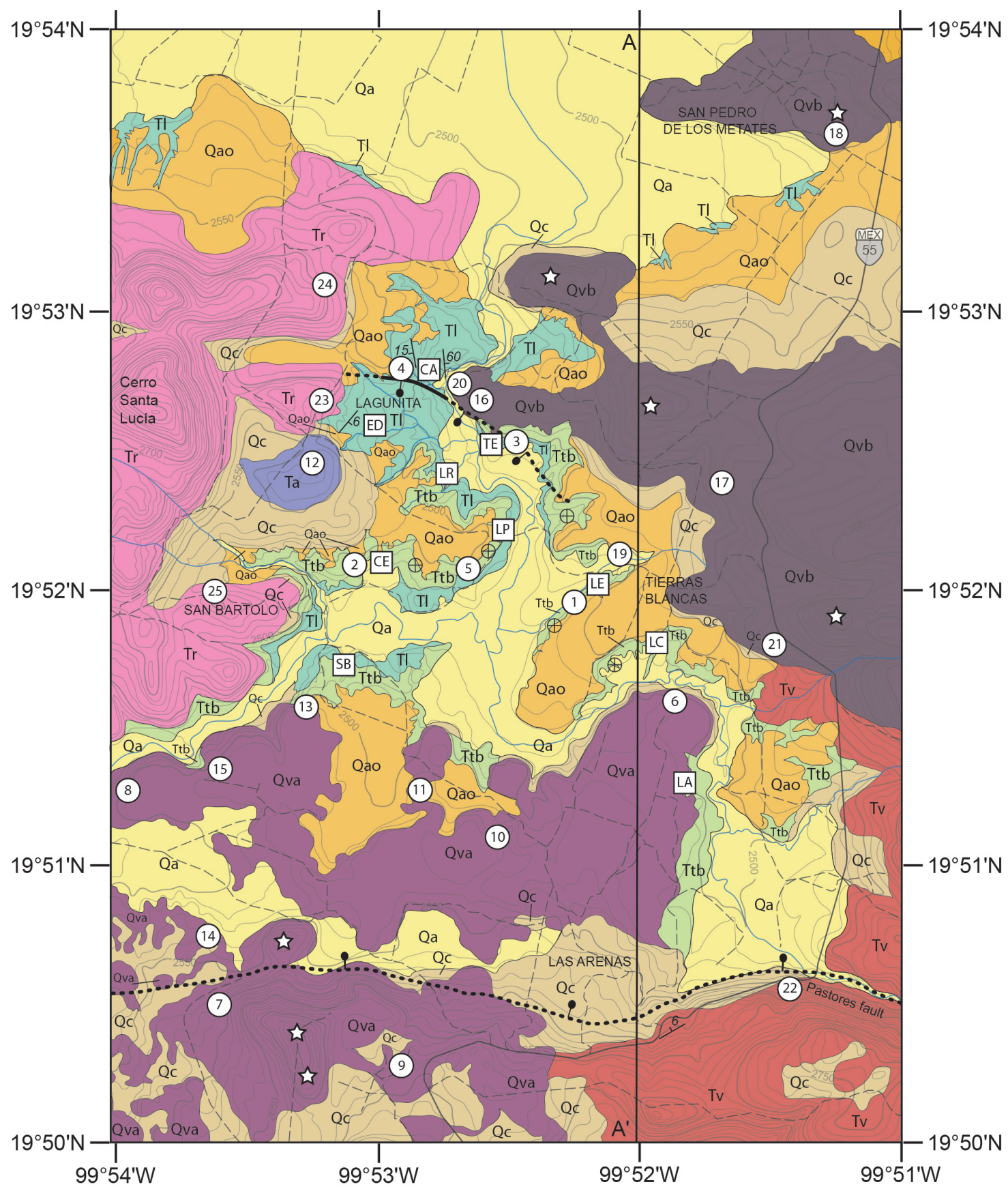

SCALE $1: 50,000$

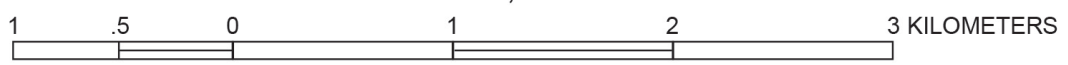

CONTOUR INTERVAL 10 METERS

Figure 5 (Continued on facing page). Geologic map of the Tierras Blancas area in the southeastern Acambay graben. Cross-section long line $\mathrm{A}-\mathrm{A}^{\prime}$ was selected to represent the stratigraphic context of the lacustrine Tierras Blancas beds. The numbers of the volcanic samples correspond to the numbering of volcanic rocks in Table 1A. Locality names: LA — Las Arenas, LC - Las Casas, LE—Los Espejos, CE—Cementerio de San Bartolo, SB-San Bartolo, LR - Las Represas, ED—El Durazno, TE—Línea de Teléfono, LP—La Plataforma, CA—La Cascada. 
镸阵

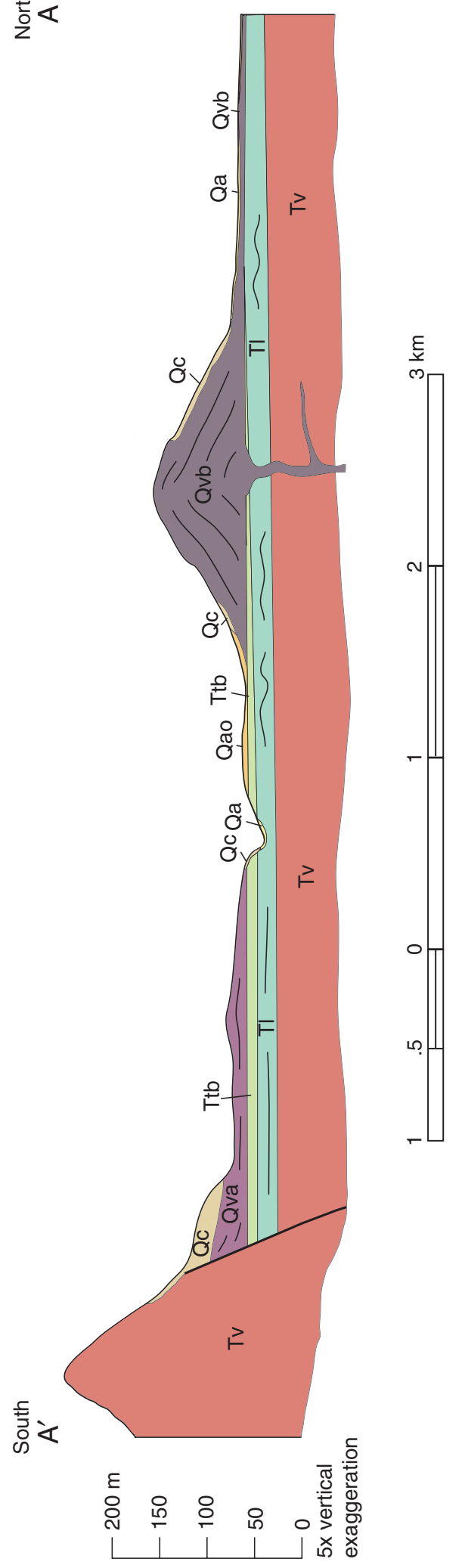

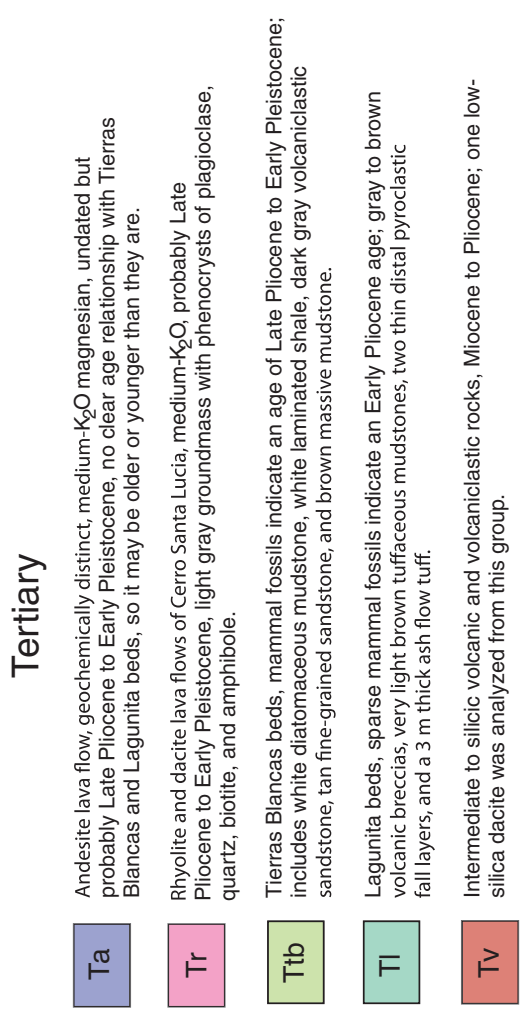

口

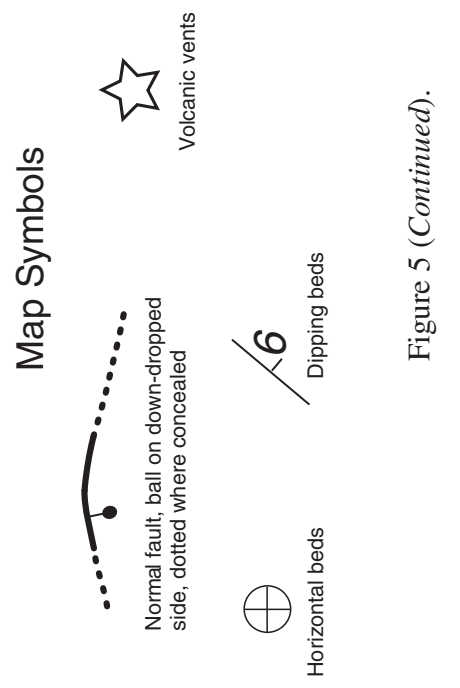




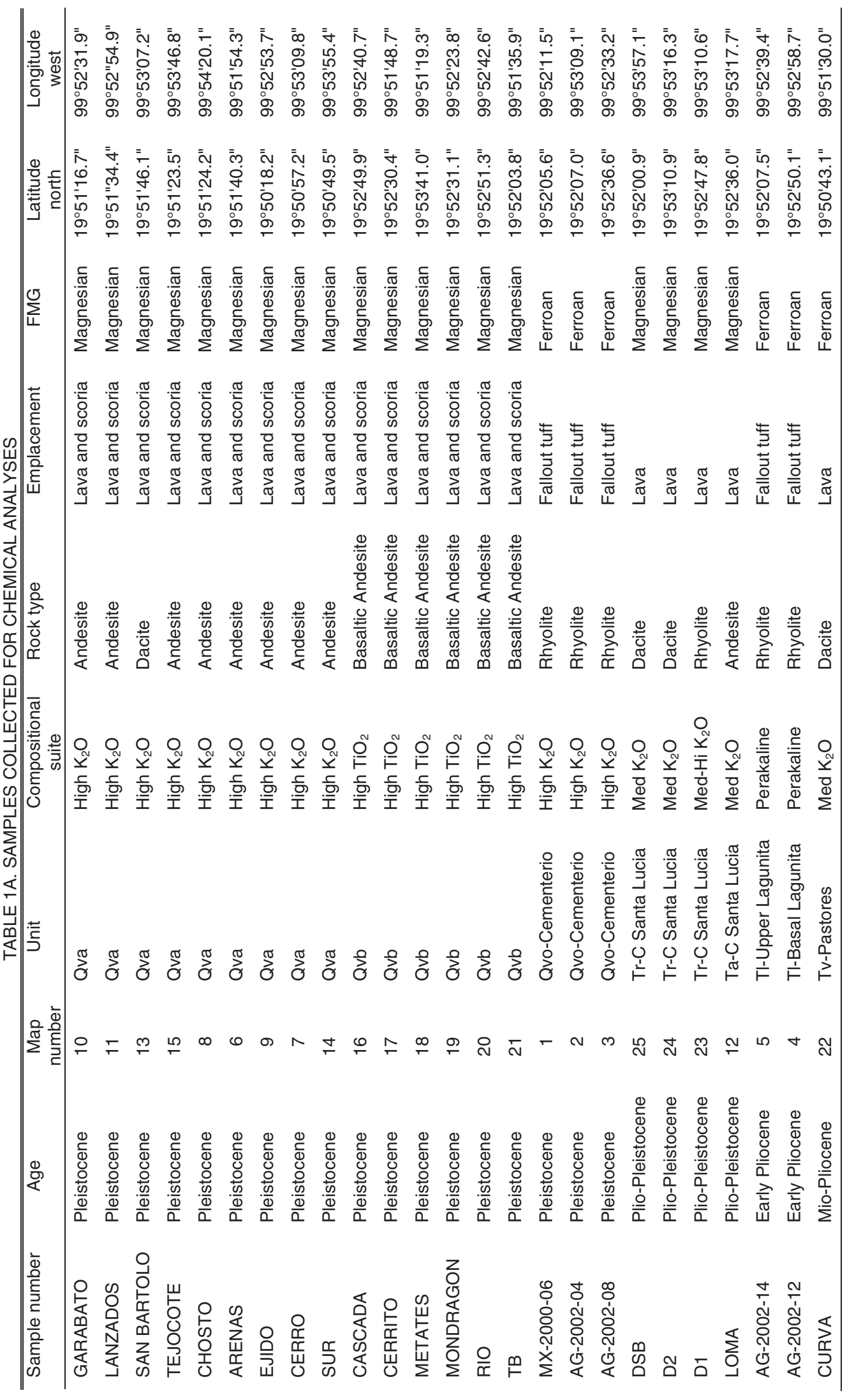




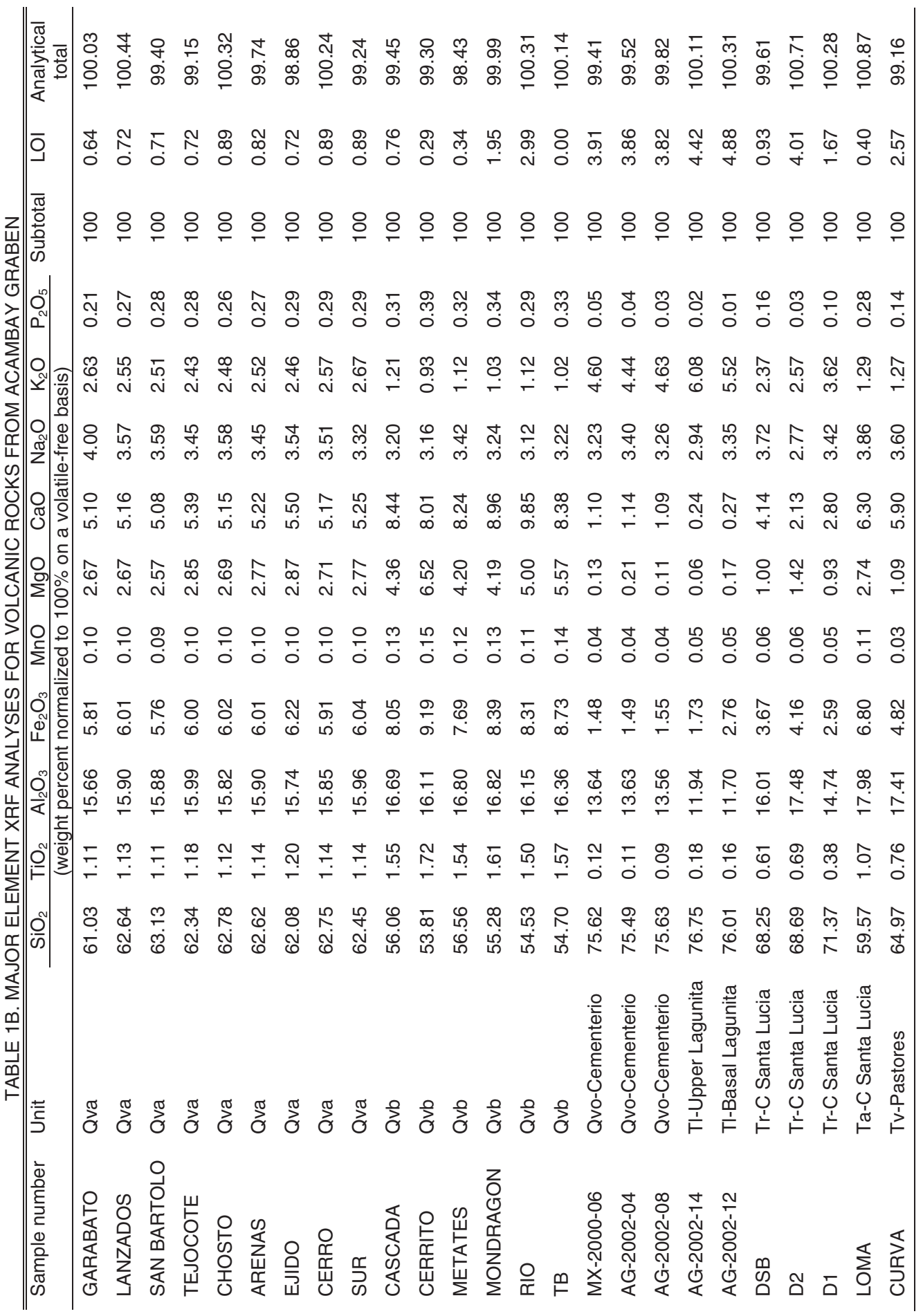




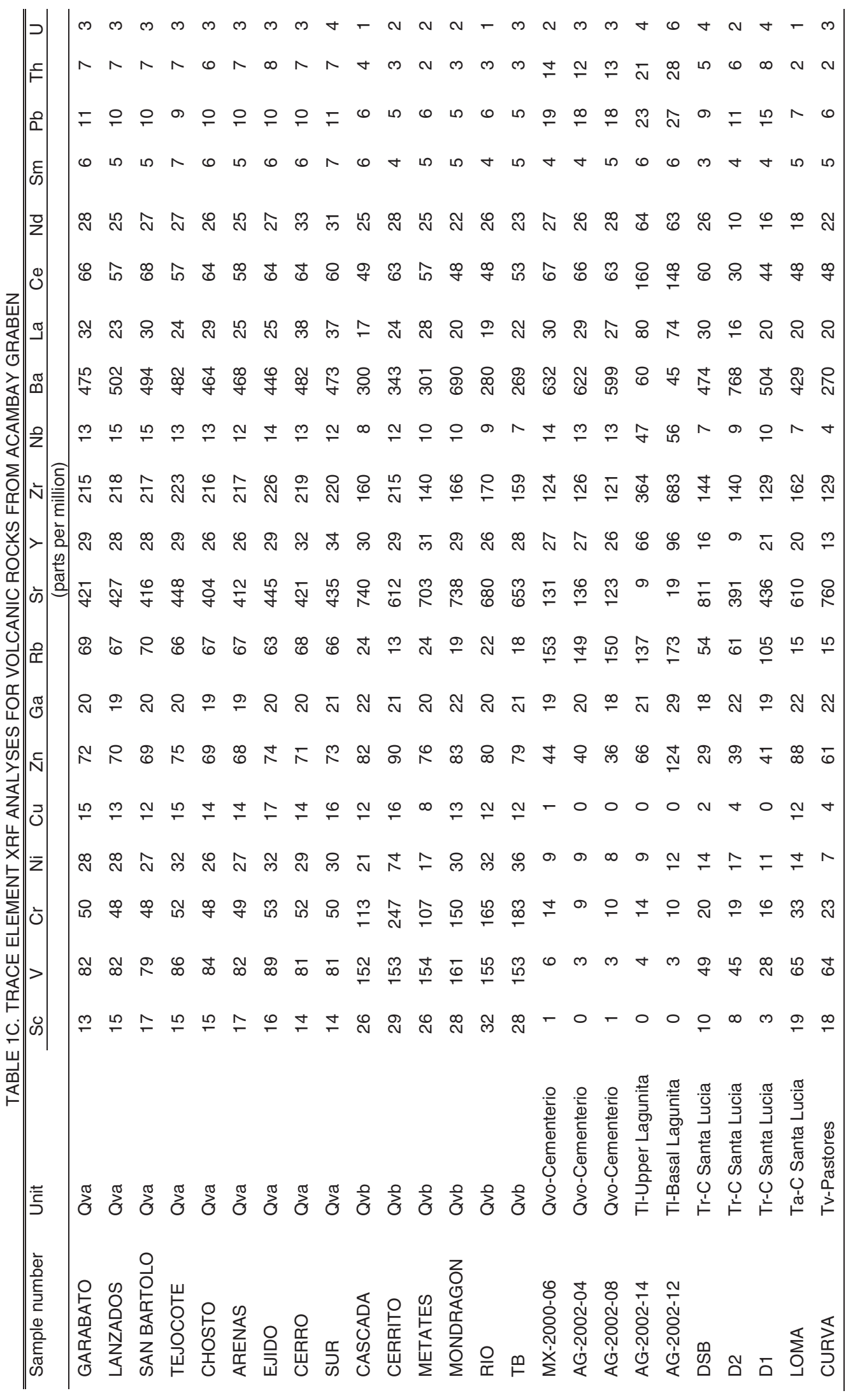




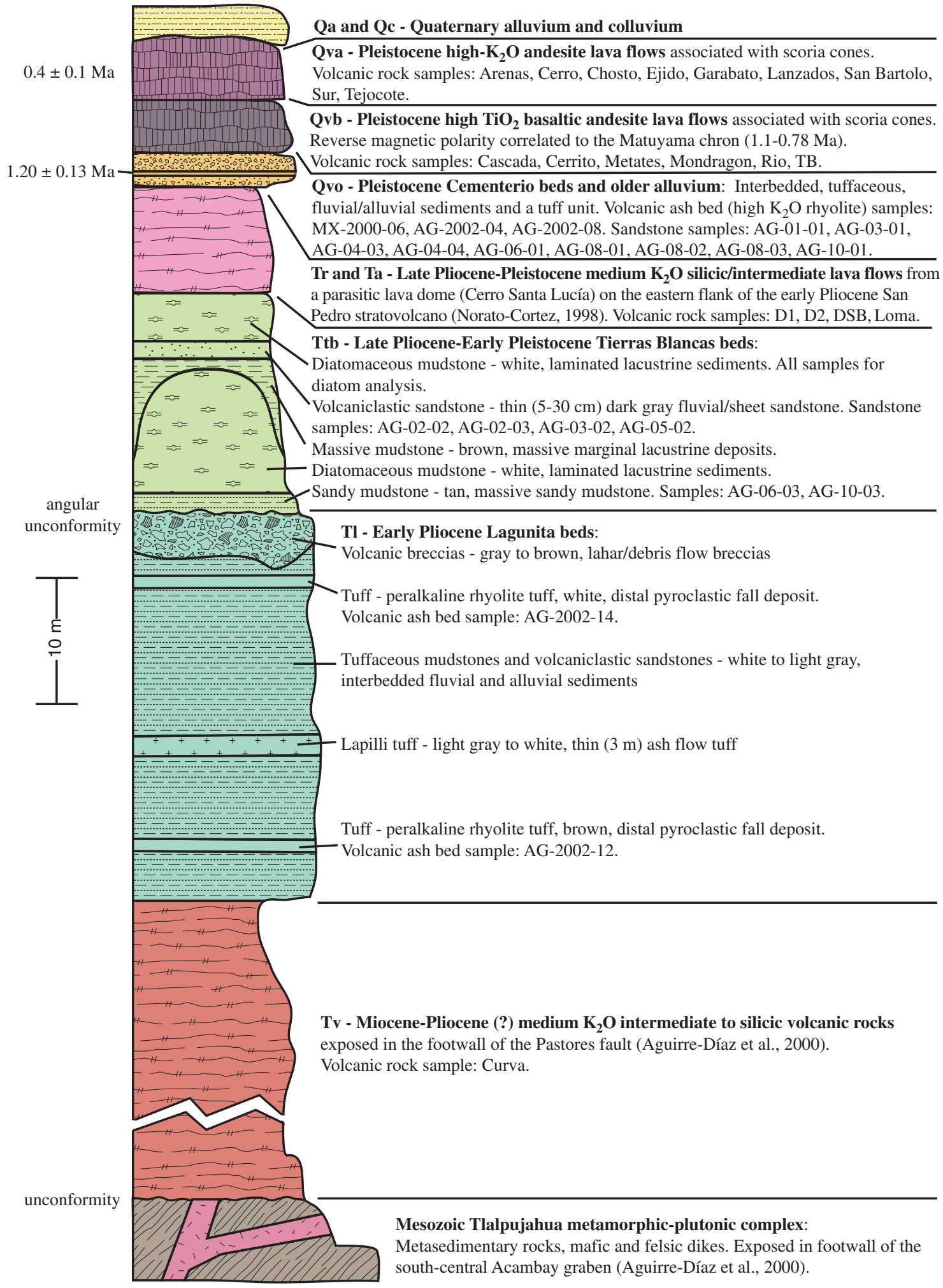

Figure 6. Composite stratigraphic section of the southeastern Acambay graben. Reversed magnetic polarity was measured in one of the lava flows near the top of the section. The sample numbers and sample names listed here are discussed in different sections of the paper. 

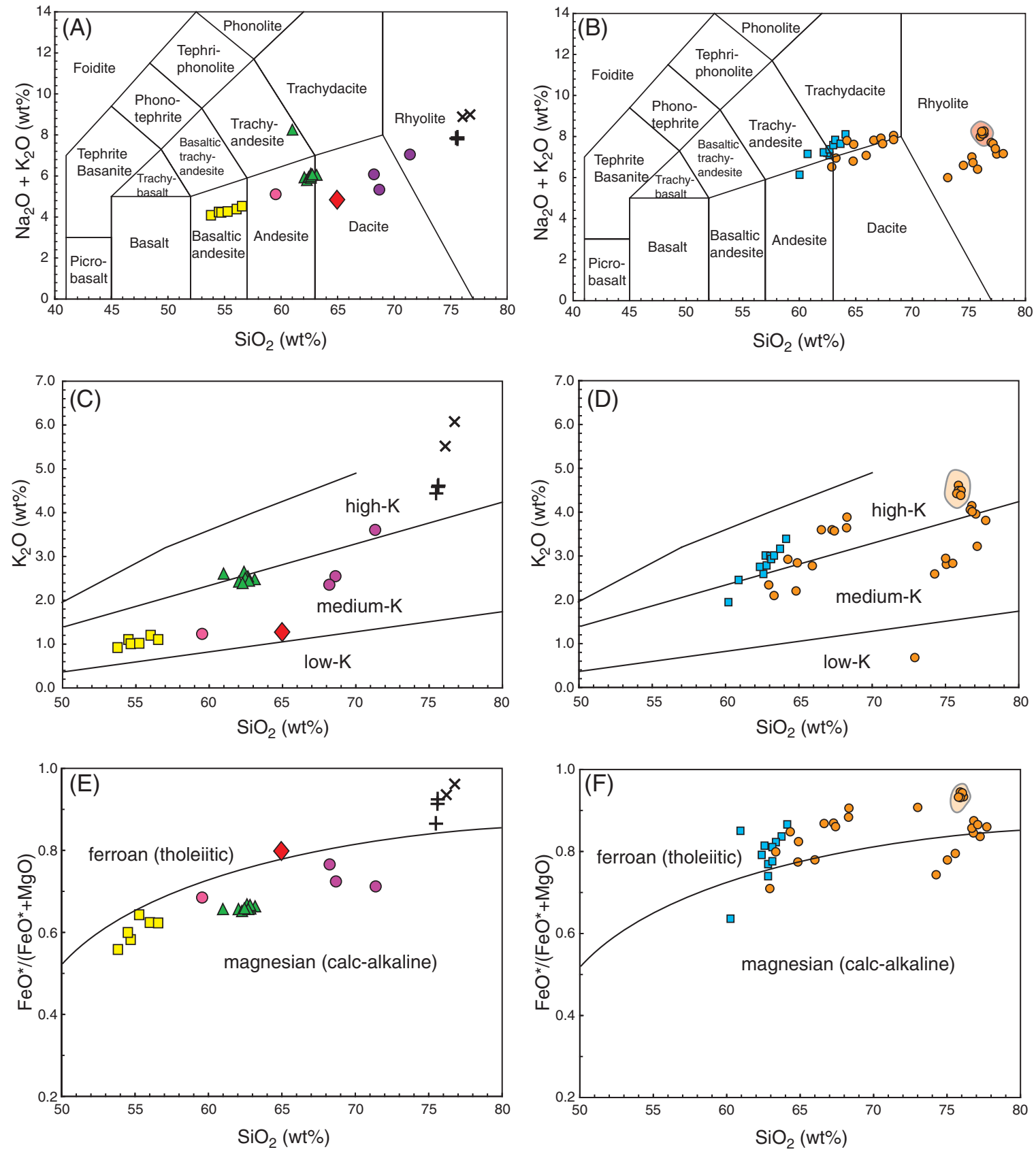

Volcanic rocks

$\triangle$ Pleistocene andesites (Qva)

$\square$ Pleistocene basaltic andesites (Qvb)

+ Pleistocene Cementerio tuff (Qvo)

- Pliocene-Pleistocene rhyolites and dacites (Tr)

- Pliocene-Pleistocene andesite (Ta)

$\times$ Pliocene Lagunita volcanic fallout tuff (TI)

$\checkmark$ Miocene-Pliocene dacite (Tv)

Volcanic lithic grains from sandstones

Lathwork and microlitic grains from upper Pleistocene Cementerio tuffaceous sandstone (AG-04-04)

- Vitric grains from upper Pleistocene Cementerio tuffaceous sandstones (AG-08-01 and AG-04-04)

Vitric grains from the basal Pleistocene Cementerio tuffaceous sandstone (AG-03-01 and AG-06-01)

Figure 7. Major element compositions of volcanic rocks (whole rock X-ray fluorescence analyses) and volcanic lithic grains from sandstones (electron microprobe analyses). 

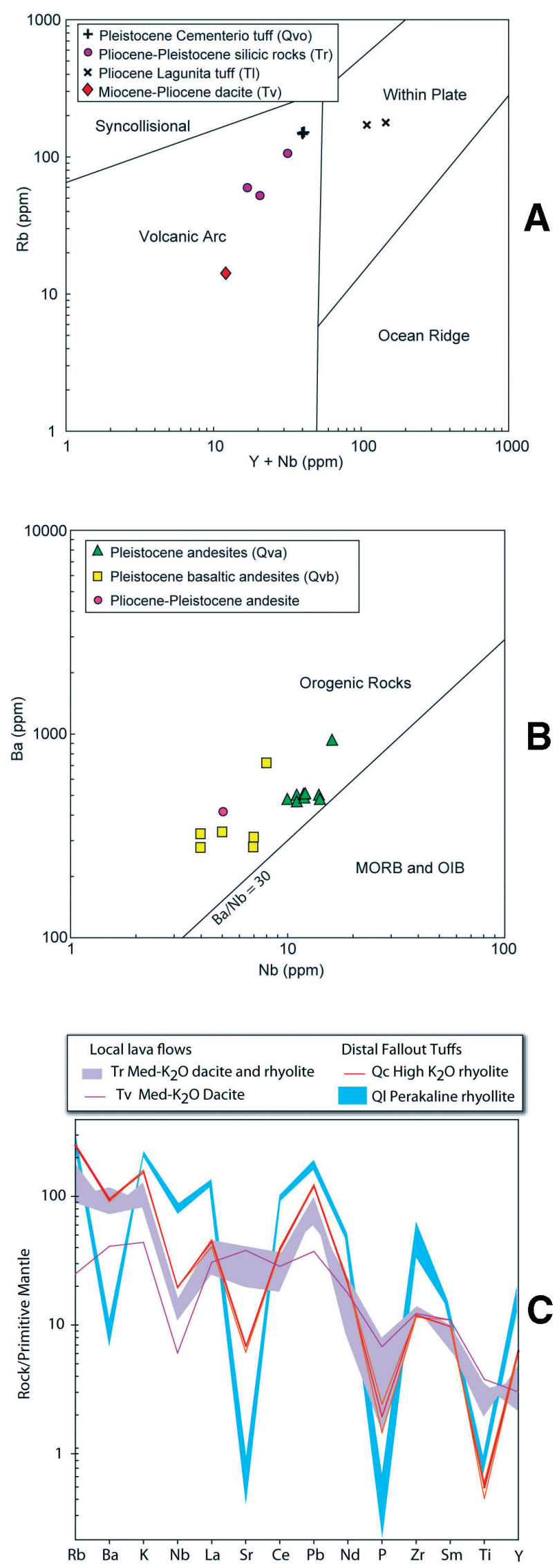

Lagunita beds, although Lagunita deposition could have continued through much of the Pliocene. The unconformity is likely due to a combination of tilting of the older beds along the listric graben bounding faults and perhaps soft-sediment deformation of these older lake beds triggered by seismic events (GarduñoMonroy et al., 2009).

The tuffaceous mudstone lithofacies is the most abundant of all the Lagunita lithofacies and is commonly interbedded with volcaniclastic sandstone. Bed thickness of the mudstone ranges from 0.5 to $3 \mathrm{~m}$. The tuffaceous mudstone is white and commonly massive with poorly-defined bedding (Fig. 12). The tuffaceous mudstone shows blocky weathering and is well-cemented. Volcaniclastic sand and gravel lenses are sparse in these tuffaceous mudstone beds. Bedding contacts of the tuffaceous mudstone commonly form conformable depositional surfaces with other lithofacies of the Lagunita beds.

Using a classification based on grain composition, the Lagunita volcaniclastic sandstones are lithic arenites (Dott, 1964) or volcaniclastic sandstones (Fisher, 1961; Boggs, 1995). The Lagunita volcaniclastic sandstone beds are fine- to coarsegrained and range from thinly to thickly bedded (Fig. 13). These sandstones are commonly gray with planar lamination and ripple cross-lamination $(1-4 \mathrm{~cm})$. Sand grains are angular to subangular, poorly to moderately sorted, and poorly cemented with zeolite. The sandstones contain a high percentage of epiclastic volcanic lithic and feldspar grains. Gastropod shell fragments $(2-3 \mathrm{~cm}$ wide for whole shells) are found in a few sandstone beds.

Graded beds and cut-and-fill structures (generally $1.5 \mathrm{~m}$ in width by $0.2 \mathrm{~m}$ in height) are common. Volcaniclastic sandstone is often interbedded with tuffaceous mudstone and contains mudstone inclusions and rip-up clasts along the basal contacts of the sandstone beds.

The lapilli tuff lithofacies is a strongly resistant, $3-\mathrm{m}$ thick ash-flow tuff that is exposed laterally $\sim 50 \mathrm{~m}$. It is likely more laterally extensive, except it is cut by a normal fault at one end and disappears into alluvium at the other. The ash-flow tuff is white to gray and contains nearly $100 \%$ lapilli-sized pumice (Fig. 14). The lapilli tuff overlies tuffaceous mudstone with a sharp horizontal contact and is overlain by volcaniclastic sandstone.

The fallout tuff lithofacies was found in two localities (Fig. 5). At La Cascada, a 10-cm-thick, brown, cemented pyroclastic fall tuff (AG-2002-12) is interbedded with tuffaceous mudstones.

Figure 8. (A) $\mathrm{Rb}$ versus $\mathrm{Y}+\mathrm{Nb}$ discrimination diagram for silicic volcanic rocks from the southeastern part of the Acambay graben (modified after Pearce et al., 1984). (B) Ba versus Nb discrimination diagram for mafic to intermediate volcanic rocks from the study area. (C) Primitive mantle normalized (McDonough and Sun, 1995) trace element patterns for silicic volcanic rocks from the Acambay graben region. Dacitic and rhyolitic rocks have deep anomalies for $\mathrm{Sr}, \mathrm{P}$, and Ti as a result of fractional crystallization. The peralkaline fallout tuffs have the highest concentrations of incompatible elements and only small negative $\mathrm{Nb}$ anomalies. MORB - mid-oceanic-ridge basalt; OIBoceanic-island basalt. 

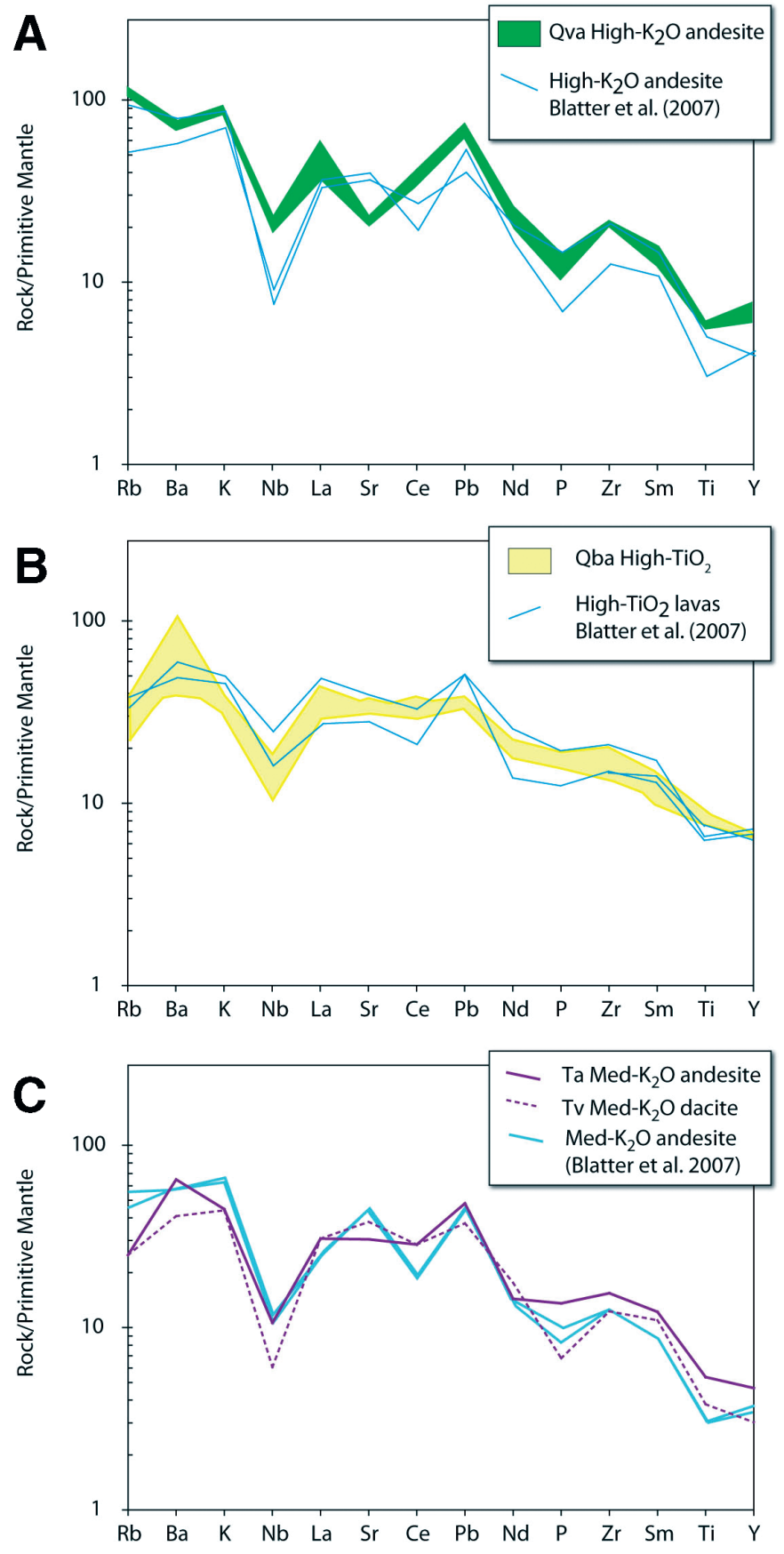

Figure 9. Primitive mantle normalized (McDonough and Sun, 1995) trace element patterns for volcanic rocks from the Acambay graben region. (A) High $\mathrm{K}_{2} \mathrm{O}$ andesites compared to representative high- $\mathrm{K}_{2} \mathrm{O}$ andesites that lack plagioclase elsewhere in the Trans-Mexican Volcanic belt (Blatter et al., 2007). Although both are similar in their high $\mathrm{K}_{2} \mathrm{O}$ concentrations, those from Acambay typically have higher $\mathrm{Nb}$ and $\mathrm{Ti}$ and lower $\mathrm{Sr}$. The patterns are interpreted to have formed by crustal contamination of high $\mathrm{TiO}_{2}$ magmas (see Fig. 50). (B) High $\mathrm{TiO}_{2}$ basaltic andesites (Qvb) compared to those described by Blatter et al. (2007). (C) Medium $\mathrm{K}_{2} \mathrm{O}$ suite ( $\mathrm{Ta}$ and $\mathrm{Tr}$ ) compared to medium $\mathrm{K}_{2} \mathrm{O}$ suite of Quaternary age (Blatter et al., 2007). The two suites are similar but those from Acambay lack positive $\mathrm{Sr}$ anomalies.

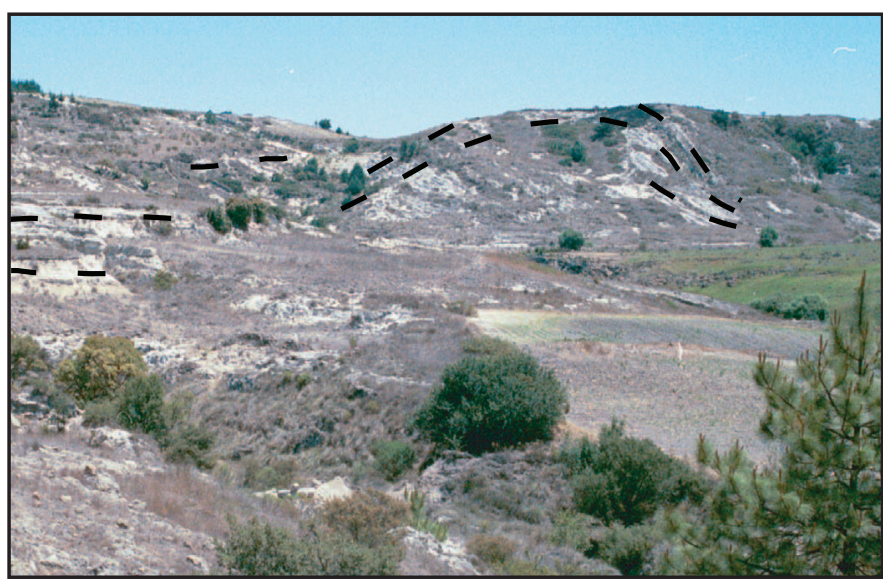

Figure 10. Looking north from the central part of the map area toward a large exposure of Lagunita beds ( $>30 \mathrm{~m}$ thick) in the background. An anticline in the Lagunita beds underlies the hill in the background (right side). The deformation in these beds is likely due to soft sediment deformation produced by rapid deposition of volcanic debris flows on top of fluid saturated, unconsolidated, mud-rich sediments below. The hill is part of the La Cascada locality.

This tuff lies in the lower part of the exposed Lagunita section (Fig. 6) and contains a significant amount of clay, $>50 \%$ glass, and $<10 \%$ minerals.

Another fallout tuff unit crops out along the dirt road near La Plataforma; this tuff (AG-2002-14) is a white, poorly cemented pyroclastic fall tuff with glass shards forming at least $90 \%$ of the tuff. Although limited exposure obscures its relationship with other lithofacies in the Lagunita beds, it appears to lie a couple of meters below the Lagunita-Tierras Blancas contact and is, therefore, higher in the stratigraphic section than the tuff bed represented by sample AG-2002-12 (Fig. 6).

These two tuff beds are distal pyroclastic fall deposits. Glass fractions from the tuffs are rhyolitic in composition and plot as high-K and ferroan (Fig. 7). Both of the Lagunita fallout tuffs have high concentrations of many incompatible elements $(\mathrm{U}, \mathrm{Th}$, $\mathrm{Pb}, \mathrm{Nb}, \mathrm{Y}, \mathrm{LREE})$ compared to any of the other silicic rocks. On a normalized trace element diagram (Fig. 8C) they show strong depletions of compatible elements, including $\mathrm{Ba}, \mathrm{Sr}$, $\mathrm{Ti}$ and $\mathrm{P}$, indicating extensive fractionation of alkali feldspar and plagioclase, Fe-Ti oxides, and apatite. On the other hand, they are enriched in $\mathrm{Zr}$ rather than depleted like most high-silica rhyolites. Moreover, they have low $\mathrm{Pb} / \mathrm{Ce}$ ratios. Due to their high $\mathrm{Nb}$ and $\mathrm{Y}$ content, they plot in the "within plate" or "A-type" region of the Pearce et al. (1984) discrimination diagram (Fig. 8), in contrast to other silicic rocks in this area. Like most other, A-type rhyolites they also have high concentrations of $\mathrm{Zr}$, Zn, and $\mathrm{Ga}$. The Lagunita tuffs are also unusual compared to normal continental arc volcanic rocks in their relatively low concentrations of $\mathrm{MgO}$, $\mathrm{Al}_{2} \mathrm{O}_{3}$, and $\mathrm{CaO}$ as well as relatively high $\mathrm{Fe}_{2} \mathrm{O}_{3}$ and $\mathrm{TiO}_{2}$ (Fig. 15). All of the data show that these are marginally peralkaline tuffs even though they lack normative acmite. They may have lost $\mathrm{Na}_{2} \mathrm{O}$ after eruption, perhaps due to post-depositional leaching. 


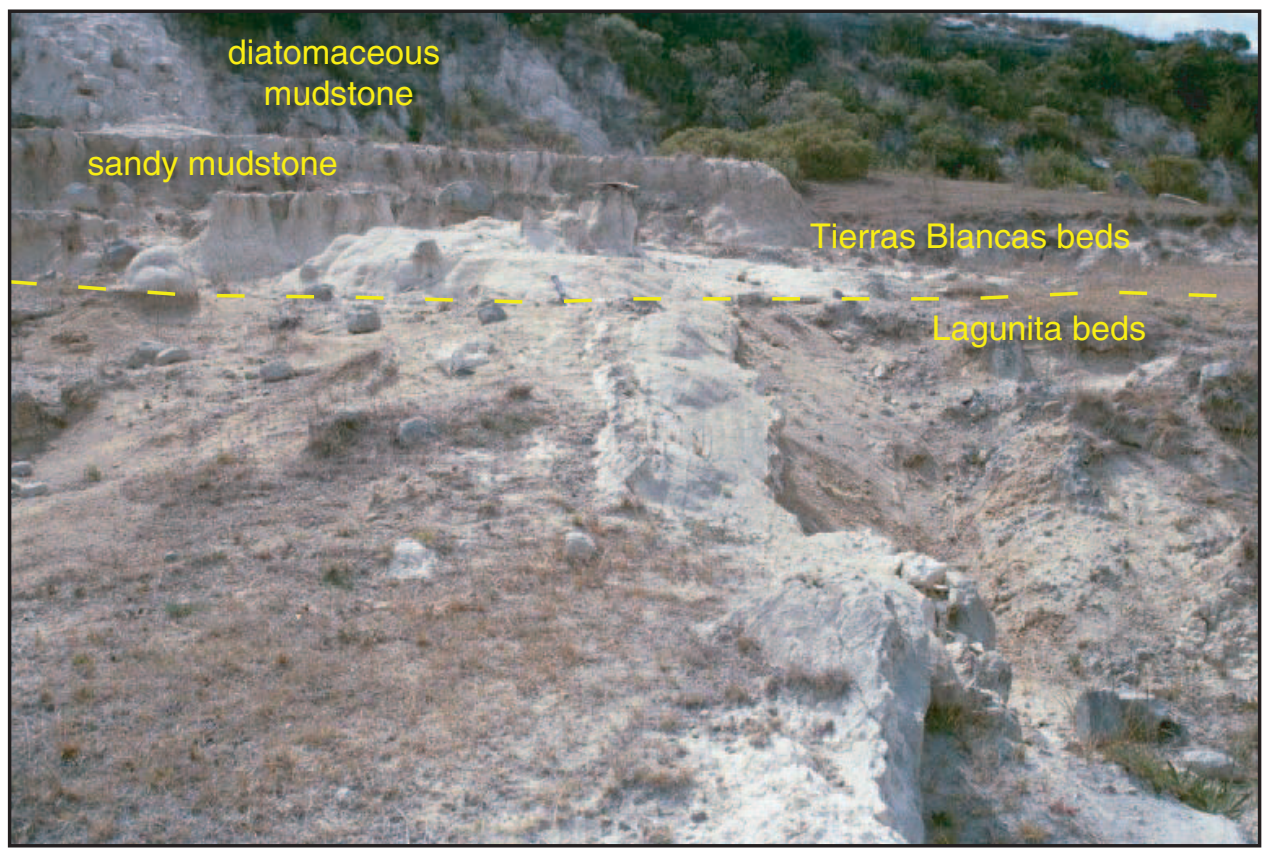

Figure 11. Angular unconformity between the dipping Lagunita beds (foreground) and the horizontal Tierras Blancas beds (background) at the $\mathrm{La}$ Plataforma locality. At least 5-6 horse (Equus simplicidens) teeth were collected from the sandy mudstone bed of the Tierras Blancas beds here.

Eruptions of peralkaline rhyolite were rare during the Miocene and Pliocene of the Trans-Mexican Volcanic Belt, but have been identified in three places. Peralkaline pyroclastic flows erupted from Amazcala caldera near Queretaro between 7 and $6 \mathrm{Ma}$ (Aguirre-Díaz and Lopez-Martinez, 2001). This caldera is only $\sim 100 \mathrm{~km}$ NNW of Acambay, but these may be too old to correlate with the tephra deposits in the Lagunita beds, which are thought to be early Pliocene ( $<5.3 \mathrm{Ma})$ in age. The peralka- line rhyolite lavas and domes of Sierra Las Navajas were erupted with small volumes of tuff $\sim 130 \mathrm{~km}$ east of Acambay between 1.8 and 4.3 Ma according to Nelson and Hegre (1990) and Ponomarenko, 2004. Finally, the Guadalajara ignimbrite is $3.3 \mathrm{Ma}$ and was erupted from a source $\sim 350 \mathrm{~km}$ away. The latter two eruptions seem either too small (Sierra Las Navajas) or too far away (Guadalajara) to have produced fallout tuffs in the Acambay graben. Therefore, the tuff layers in the Lagunita deposits

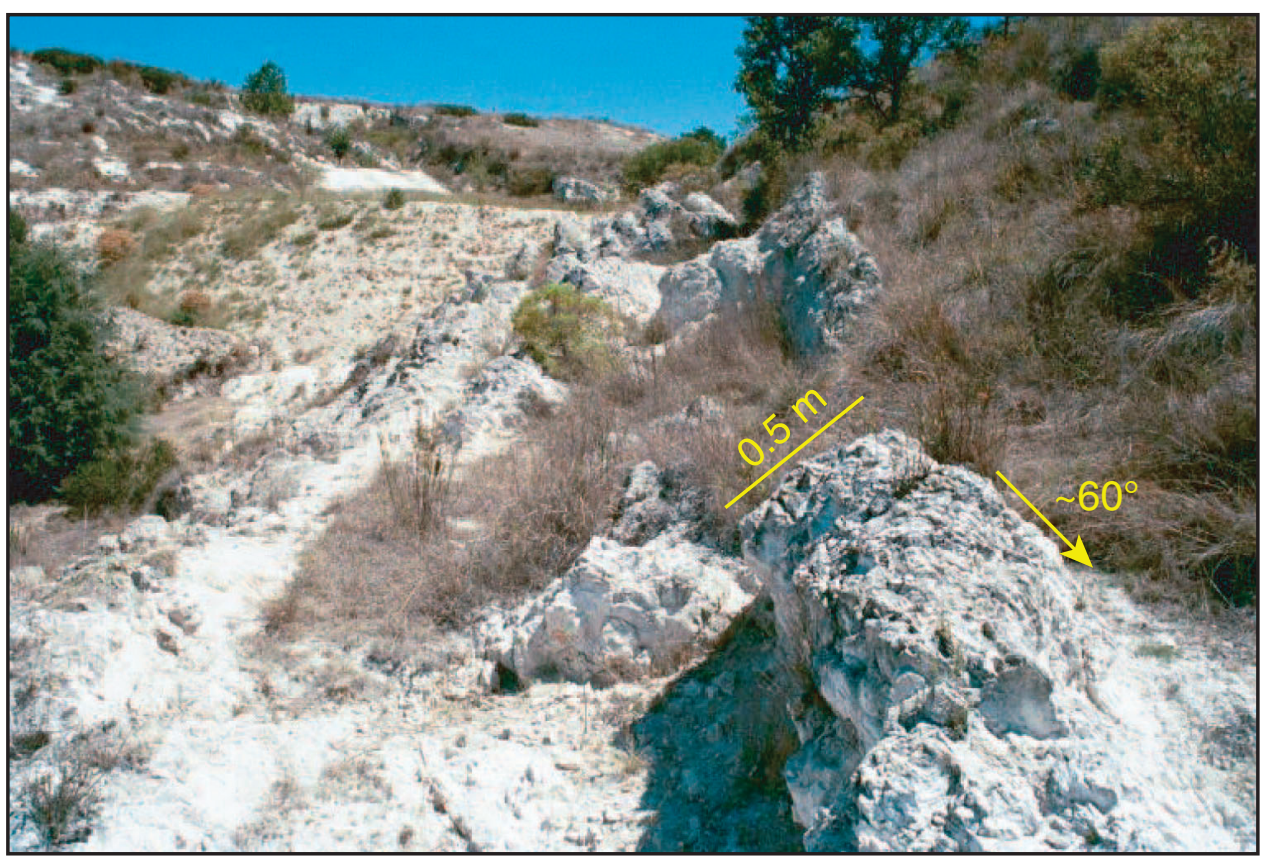

Figure 12. Tuffaceous mudstone lithofacies of the Lagunita beds in the La Cascada locality. Beds dip at $\sim 60^{\circ}$. White color is characteristic of tuffaceous mudstones, and bedding is not welldefined. The bed in the foreground is $\sim 0.5 \mathrm{~m}$ thick. 


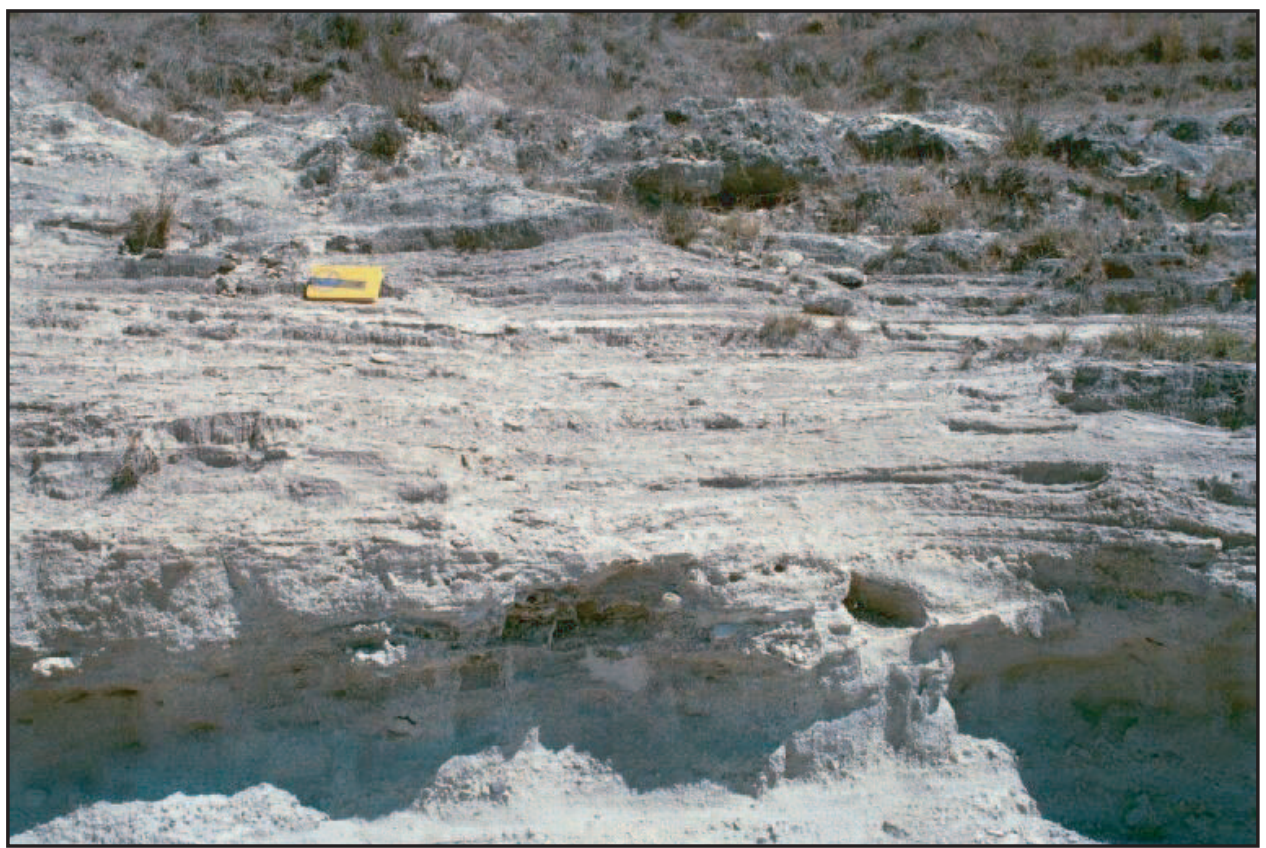

Figure 13. Volcaniclastic sandstone lithofacies of the Lagunita beds in the La Cascada locality. The sandstone is coarse-grained, moderately sorted, and thinly bedded. The notebook in the upper left of the photo is $\sim 20 \mathrm{~cm}$ long.

likely represent eruptions that have not been previously described or characterized.

The volcanic breccia lithofacies includes gray to brown breccias with angular fragments (Fig. 16) that are not laterally extensive. Volcanic clasts are mixed together, range from basaltic to felsic in composition, and form $50 \%-80 \%$ of the breccia. Clast sizes range from 1 to $30 \mathrm{~cm}$ in diameter. The matrix consists of brownish clay or gray sandy to silty ash, and the breccias tend to be strongly cemented. The volcanic breccias form erosional contacts with other Lagunita lithofacies, including channelshaped structures (3-5 m thick) that likely represent fairly fluid volcanic debris flow or lahar deposits. The Pliocene lahars in the Lagunita beds probably originated from the nearby San Pedro stratovolcano whose central vent is $\sim 10 \mathrm{~km}$ to the west (Fig. 3) and erupted a variety of volcanic rock compositions ranging from basaltic andesite to rhyolite.

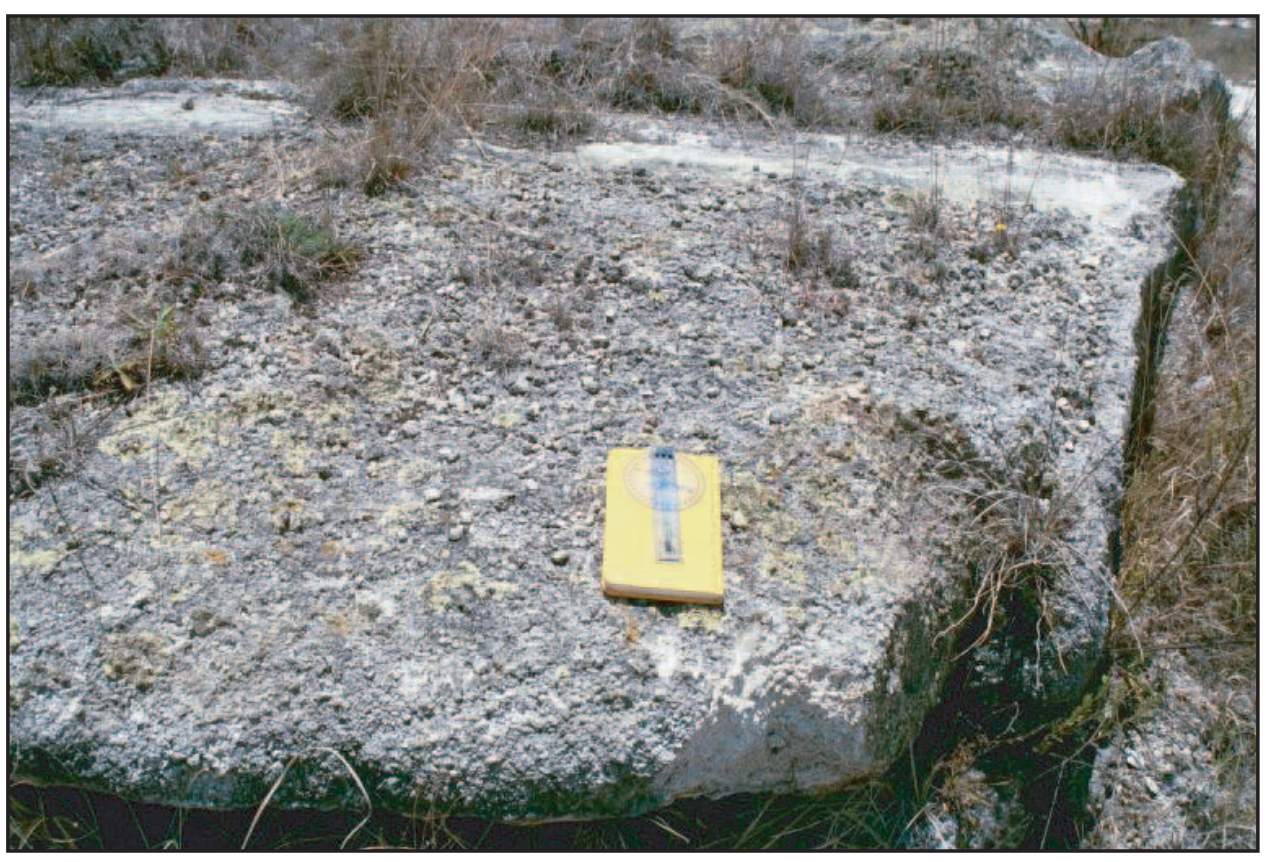

Figure 14. Lapilli tuff lithofacies of the Lagunita beds in the La Cascada locality. The ash-flow tuff is almost entirely composed of lapilli-sized pumice. The tuff is cut by a meter-scale normal fault at the right-hand side of the photograph. The ruler on the notebook is $15 \mathrm{~cm}$ long. 

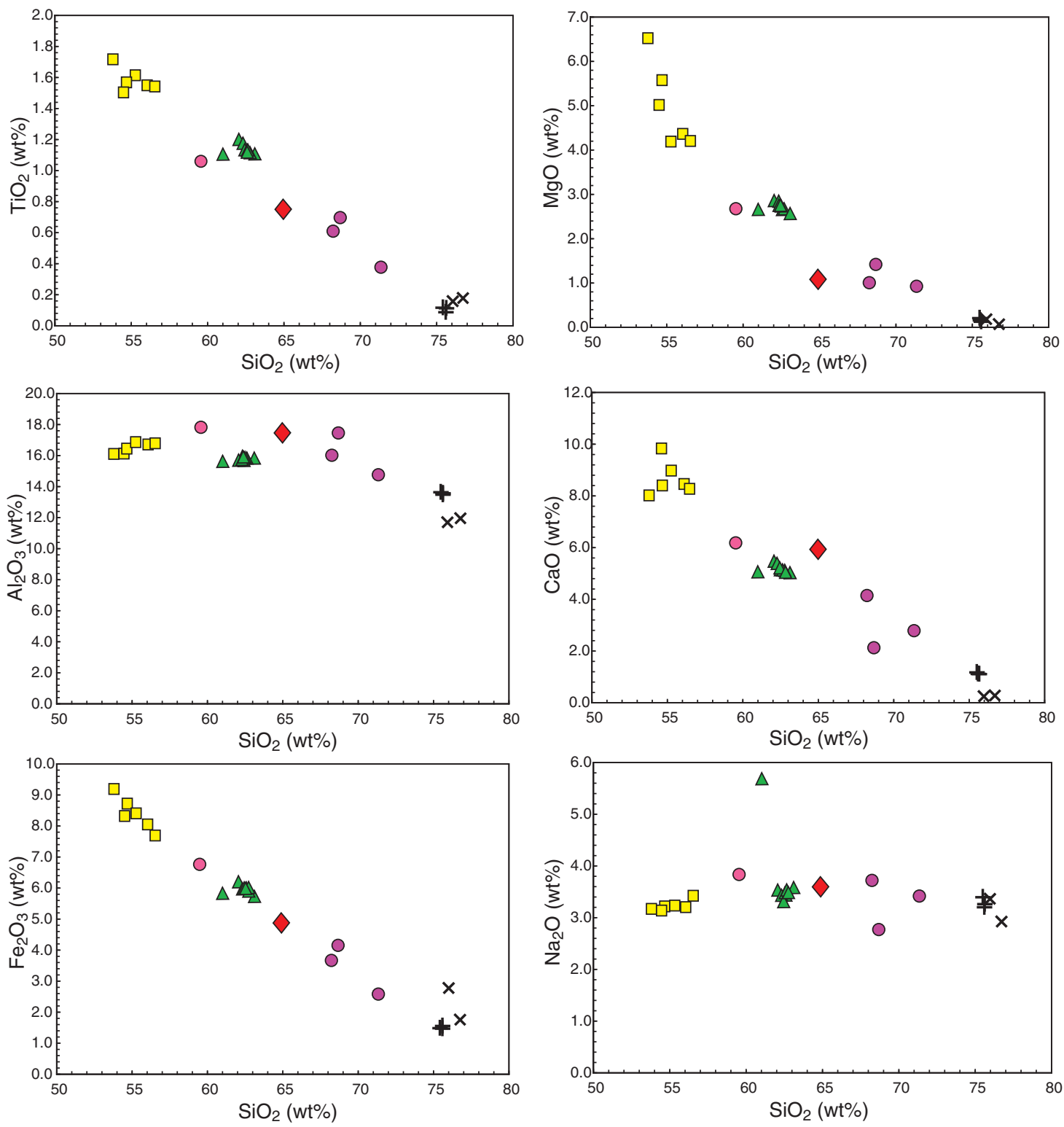

$\triangle$ Pleistocene andesites (Qva)

$\square$ Pleistocene basaltic andesites (Qvb)

+ Pleistocene Cementerio tuff (Qvo)

- Pliocene-Pleistocene rhyolites and dacites ( $\mathrm{Tr}$ )

O Pliocene-Pleistocene andesite ( $\mathrm{Ta}$ )

$\times$ Pliocene Lagunita volcanic fallout tuff (TI)

Miocene-Pliocene dacite (Tv)

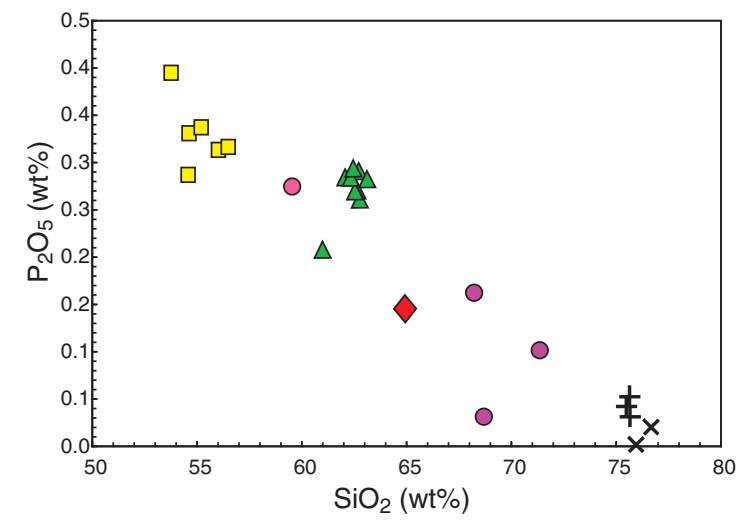

Figure 15. Silica variation diagrams for volcanic rocks in the Acambay graben as determined by X-ray fluorescence analysis of whole rocks. 


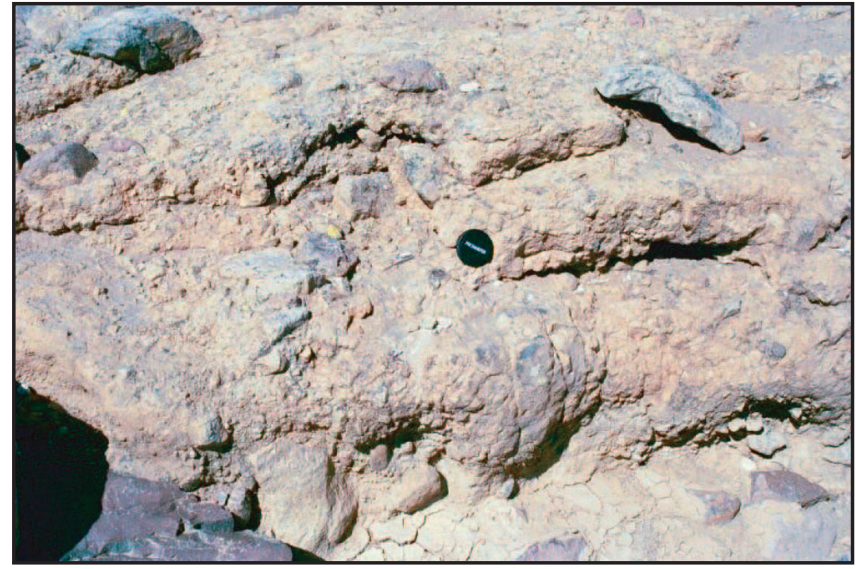

Figure 16. Volcanic breccia lithofacies of the Lagunita beds in the El Durazno locality. The matrix is light brown, and clast compositions generally range from intermediate to mafic. Camera lens cap for scale.

Deformation is common, but not pervasive in the Lagunita beds throughout the field area. In the La Plataforma locality, the Lagunita beds are dipping $\sim 45-50^{\circ}$ beneath horizontally bedded Tierras Blancas beds (Fig. 11). Tilted bedding of the Lagunita beds is also common in other localities, although exposure is generally limited to a few meters obscuring possible larger structures.

The Lagunita beds are best exposed in the La Cascada locality, where $\sim 30 \mathrm{~m}$ of Lagunita beds crop out on a hillside exposing a 10-m-scale fold (Fig. 10). Bedding attitudes were measured along the fold, and poles to bedding were plotted on an equalarea stereonet (Fig. 17). The stereoplot reveals an east-west trend in the poles to bedding, which indicates a north-south trend of the fold's axial plane and a near horizontal north-south fold axis. Closely-spaced fractures and joints ( $<5 \mathrm{~cm}$ spacing) are pervasive in the Lagunita beds and appear to be associated with folding.

These folds are likely not the result of tectonic compression. The Acambay graben, an extensional structure, was actively forming at the time the Lagunita beds were being deposited (Garduño-Monroy et al., 2009). We propose that these folds formed as soft-sediment structures, perhaps triggered by the rapid emplacement of the Lagunita volcanic breccias as lahars. These volcanic deposits may have also been accompanied by seismic activity, which could have further aided in their formation. Folds formed in a similar fashion have been observed in the Huckleberry Ridge Tuff near Yellowstone National Park in Idaho. Embree and Hoggan (1999) explain that large folds in the Huckleberry Ridge Tuff formed as a result of rapid deposition of the ash flow (loading) atop fluid saturated, unconsolidated sediments, followed by lateral spreading of the still warm, plastic lower part of the ash flow. In the Lagunita beds, rapid deposition of the lahars on top of the unconsolidated, fluid saturated muds and tuffs below could have created a similar situation.

\section{Late Pliocene-Early Pleistocene Tierras Blancas Beds (Ttb)}

The Tierras Blancas beds unconformably overlie the Lagunita beds forming an angular unconformity in areas where the Lagunita beds are deformed (Fig. 11). The Tierras Blancas beds (Fig. 6) are mudstones (2-15 m thick) with thin interbedded volcaniclastic sandstone beds (5-30 cm thick). The Tierras Blancas beds are here divided into four lithofacies: (1) sandy mudstone, (2) diatomaceous mudstone, (3) massive mudstone, and (4) volcaniclastic sandstone. The Tierras Blancas beds
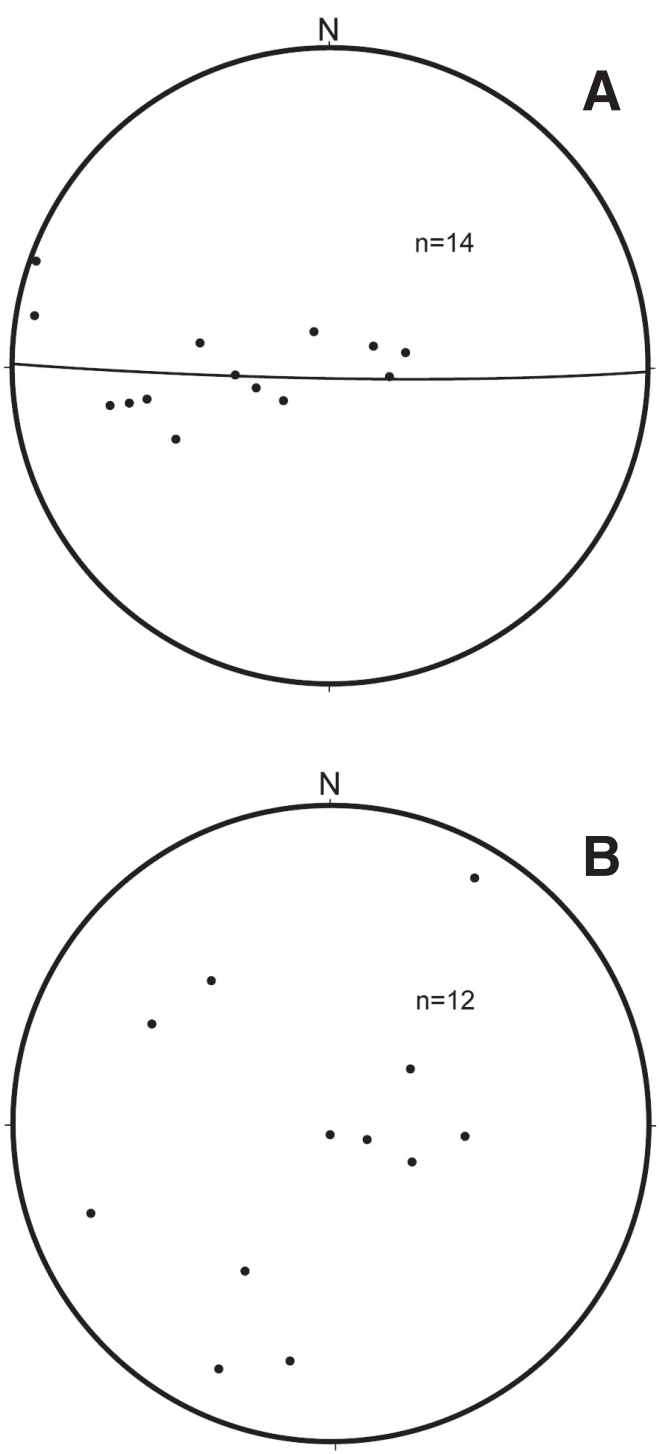

Figure 17. (A) Equal-area stereoplot of poles to bedding planes from Lagunita beds in the La Cascada locality (see Figs. 5 and 9). The east-west-trending great circle indicates the trend of the poles. The axial plane of the fold is not plotted but has a north-south trend. (B) Equalarea stereoplot of poles to bedding planes from deformed Tierras Blancas beds throughout the study area. The scatter of the data indicates the deformation in the Tierras Blancas beds is unsystematic. 
are the most productive in terms of mammal fossils yielding ?Camelops, cf. Rhynchotherium, and at least 20 elements of Equus simplicidens, including a skull with upper dentition (Fig. 18). Radiometric age determinations have not been obtained from units within the Tierras Blancas beds, but a late Pliocene age-earliest Pleistocene age is assigned with confidence to Tierras Blancas deposition because of key Blancan mammal fossils. The Tierras Blancas diatom assemblage also indicates a Pliocene-early Pleistocene age of deposition due to the presence of Stephanodiscus excentricus (Michaud et al., 2000). The stratigraphic relationship with a dated volcanic ash bed $(1.20 \pm$ 0.13 Ma fission track age; Fig. 19) lying less than one meter above the Tierras Blancas beds also suggests late Plioceneearly Pleistocene deposition.

The sandy mudstone lithofacies is the basal unit of the Tierras Blancas beds and ranges in thickness from 1 to $2 \mathrm{~m}$. It has a tan to buff color, is massive, commonly resistant, and forms a platform at the base of the Tierras Blancas outcrops (Fig. 11). The mudstone is $80 \%-90 \%$ tan clay with $10 \%-20 \%$ angular to subangular lithic sand grains.

Plagioclase and volcanic lithic grains dominate the sand grain assemblages. Quartz, Fe-Ti oxides, pyroxene, and amphibole are accessory minerals that comprise a minor component of

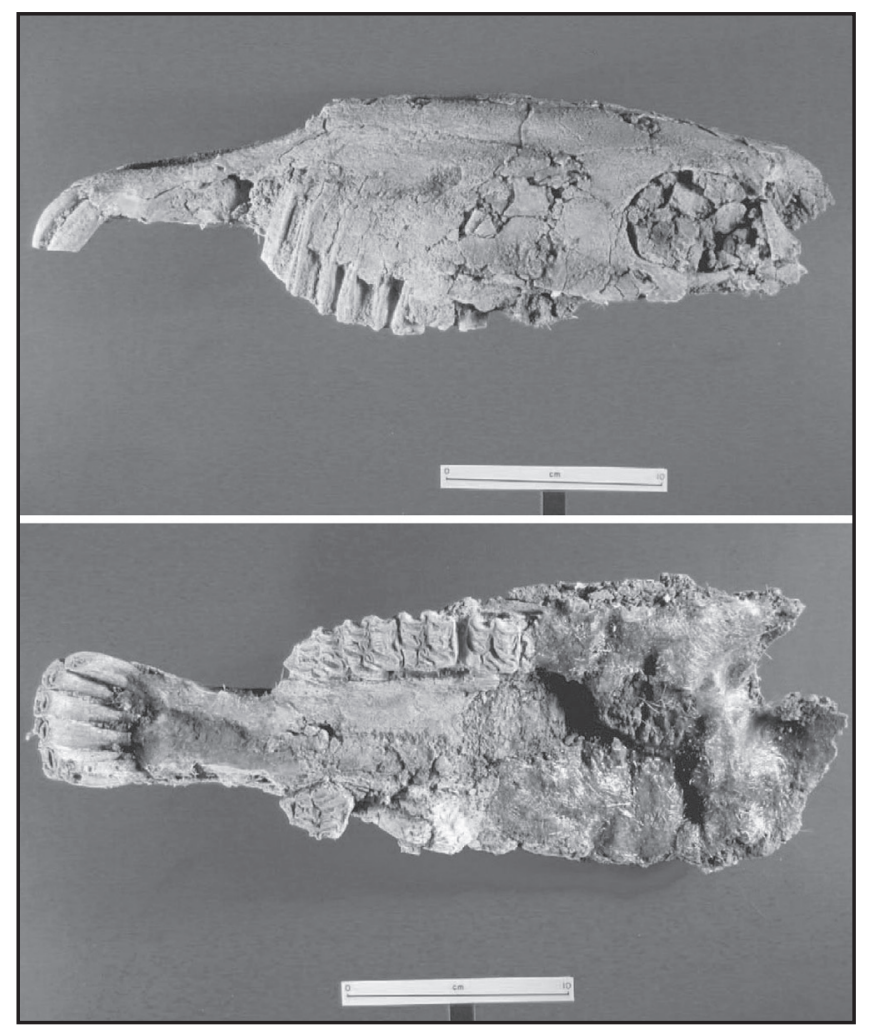

Figure 18. Lateral and ventral views of the upper jaw and skull of Equus simplicidens found in the Las Casas locality (see Fig. 3). The skull was found in the diatomaceous mudstone lithofacies of the Tierras Blancas beds. Note $10 \mathrm{~cm}$ scale. the grains. Detrital matrix and zeolite cement are the major interstitial materials and likely formed from very fine volcanic ash.

The Tierras Blancas sandy mudstones plot in the transitional arc provenance subdivision of Dickinson et al. (1983; Fig. 20). Sparse volcanic pebbles and cobbles are found near the base of the sandy mudstone, which also contains organic material and root traces. At least 15 mammal fossils representing Equus simplicidens and cf. Rhynchotherium have been recovered from this unit. The sandy mudstone always shows horizontal bedding.

The diatomaceous mudstone lithofacies lies conformably on top of the sandy mudstone and ranges in thickness from 1 to $15 \mathrm{~m}$. This unit thins and pinches out to the northwest, but lateral thinning is difficult to determine in other areas due to limited exposure. The diatomaceous mudstone is commonly horizontally bedded but locally shows significant nonsystematic, soft-sediment
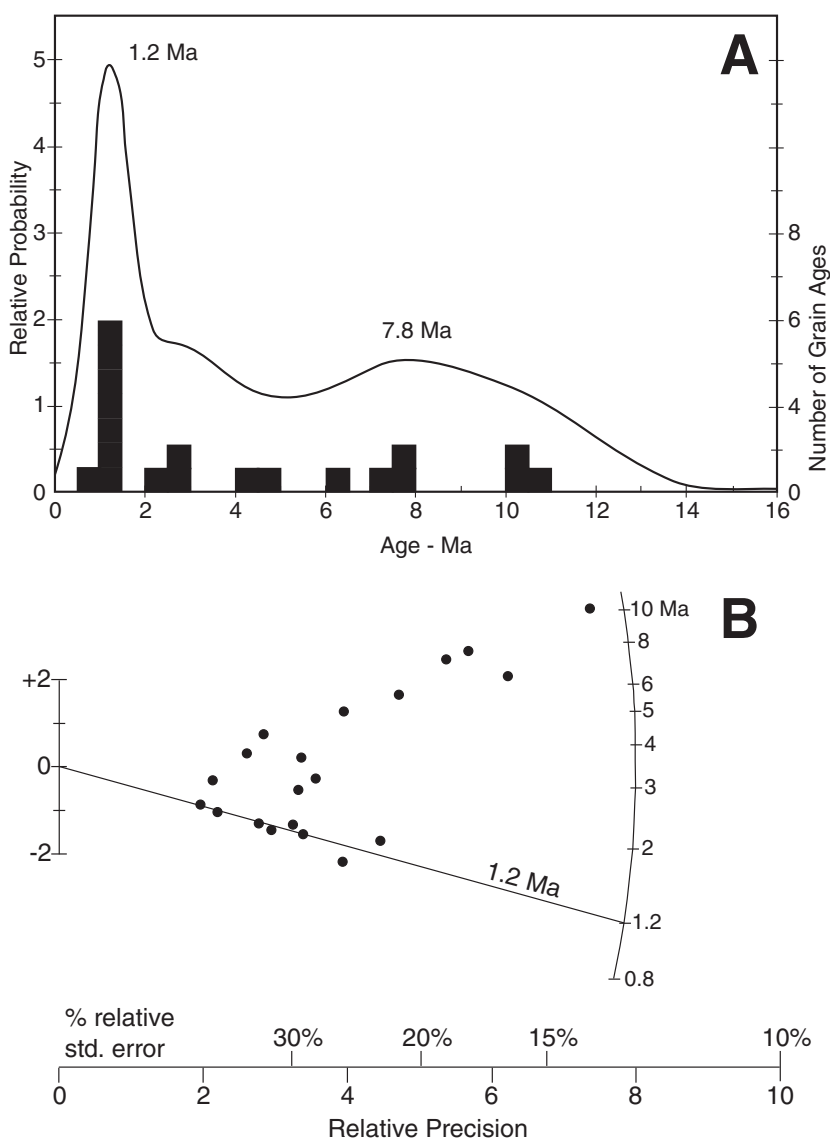

Figure 19. Fission track zircon data for sample MX-2000-6 from the Cementario beds, approximately one meter above the contact with the Tierras Blancas beds. (A) Relative probability plot (Hurford et al., 1984; Kowallis et al., 1986) showing age peaks at 1.2 and 7.8 Ma. Individual grain ages are shown in the histogram at the bottom of the diagram. The young age peak at $1.2 \mathrm{Ma}$ is taken to be the eruption age for the ash and the scatter of older ages up to $\sim 10 \mathrm{Ma}$ are detrital contaminants. (B) Radial plot (Galbraith, 1988, 1990) of grain ages also shows the cluster at $\sim 1.2$ and the scatter of older ages. 


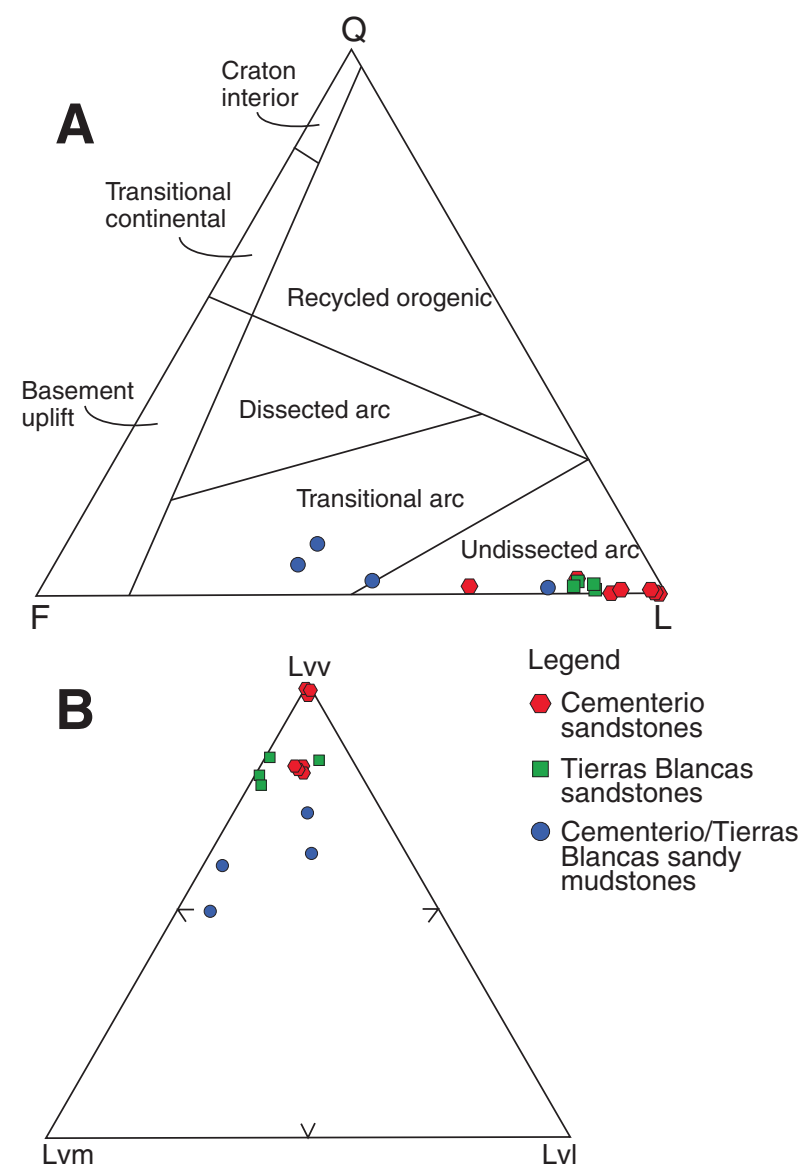

Figure 20. Ternary diagrams of Tierras Blancas and Cementerio sandstones and sandy mudstones. (A) Q - quartz, Ffeldspars, L-lithic grains. Modified after Dickinson et al. (1983). (B) Ternary diagram for volcaniclastic rocks. Lvvvolcanic lithic grains with vitric texture, Lvm—volcanic lithic grains with microlitic texture, Lvl-volcanic lithic grains with lathwork texture. Modified after Critelli et al. (2002).

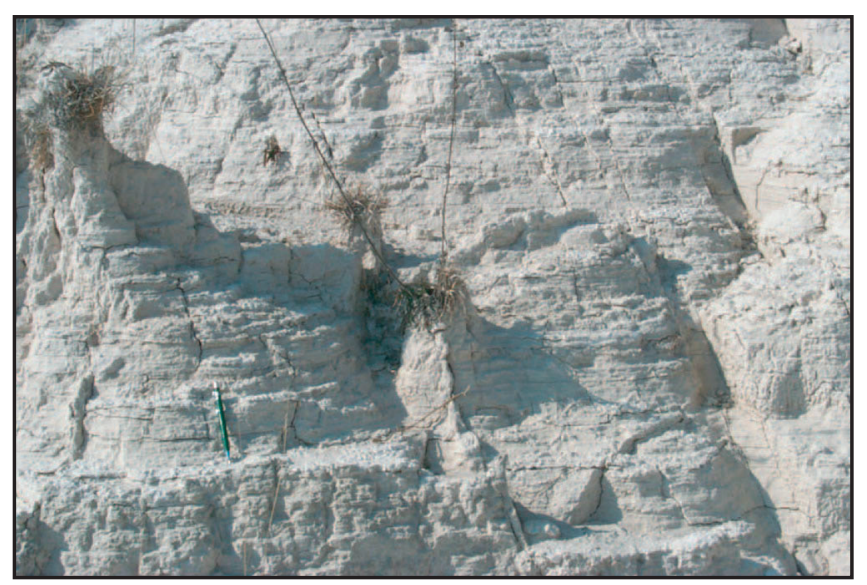

Figure 21. Diatomaceous mudstone lithofacies of the Tierras Blancas beds in the Los Espejos locality. White color and fine laminations to thin bedding are characteristic of the diatomaceous mudstone. Pencil ( $\sim 8 \mathrm{~cm}$ long) for scale. deformation and slumped bedding ranging from small centimeter sized folds to some as large as several 10s of meters.

The diatomaceous mudstones are white in color, finely laminated to thinly bedded (Fig. 21), and generally crop out as a cliffforming unit above a sharp depositional contact with the sandy mudstone lithofacies below. The mudstone is predominately a diatomite but also contains very fine ashy sediment that dominates some beds. Mammal fossils have been collected from this unit, most importantly the upper jaw and skull of Equus simplicidens from the Las Casas locality (Fig. 18).

Leaf imprints were collected in two locations from the diatomaceous mudstone (Fig. 22). The fossil plant material is currently being studied by Dr. Sergio Cevallos-Ferriz (Universidad Nacional Autónoma de México, Mexico City, Mexico). Preliminary results suggest that three species of Quercus (oak) and one species of ?Salix (willow) are represented, but further identification and analysis are needed in order to make possible paleoenvironmental interpretations from the leaf imprints. Plant material is abundant along some horizons with a general trend of increasing plant material upsection.

The diatomaceous mudstone is also marked in some localities by tubes $(\sim 5-10 \mathrm{~cm}$ in diameter) that cut across bedding and are partially or completely filled with dark brown, waxy organic debris (Fig. 23). These tunnels are interpreted to be vertebrate burrows (Stephen Hasiotis, oral communication, 2002). Small mammalian vertebrates, such as a ground squirrel, are the likely burrowers, based on the burrow size. Prairie dogs, which are also burrowers, have larger burrows with different patterns. None of the burrows appear to extend up into the younger Cementerio beds.

In addition to the dark brown to black, waxy organic material, the burrows may also be partly filled with reworked white diatomaceous mudstone. Where this occurs, the mudstone material fills in the lower part of the burrow with organic material in

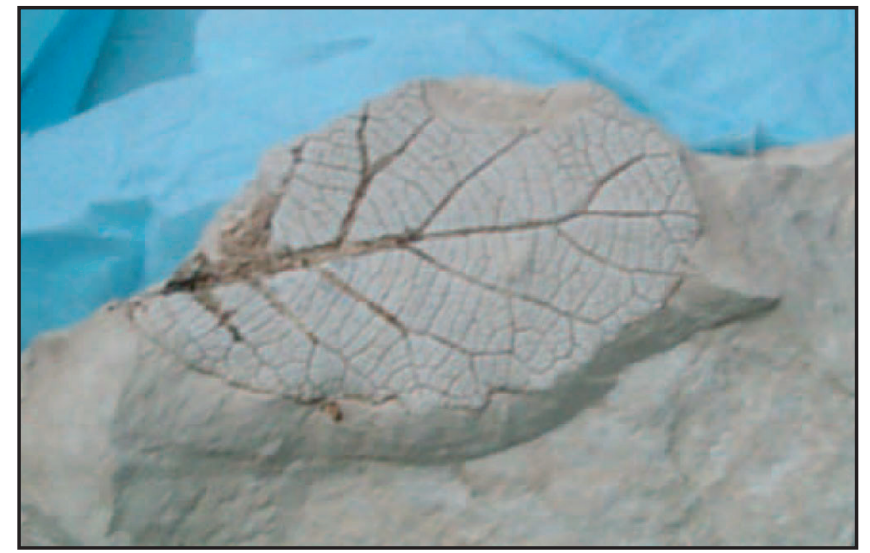

Figure 22. Leaf imprint, representing Quercus sp., collected from the Tierras Blancas diatomaceous mudstone lithofacies. Nearly all of the leaf imprints found and collected (including this sample) as part of this study were taken from an outcrop near the community of San José Toxi, which is $\sim 4-5 \mathrm{~km}$ west of the map area. 


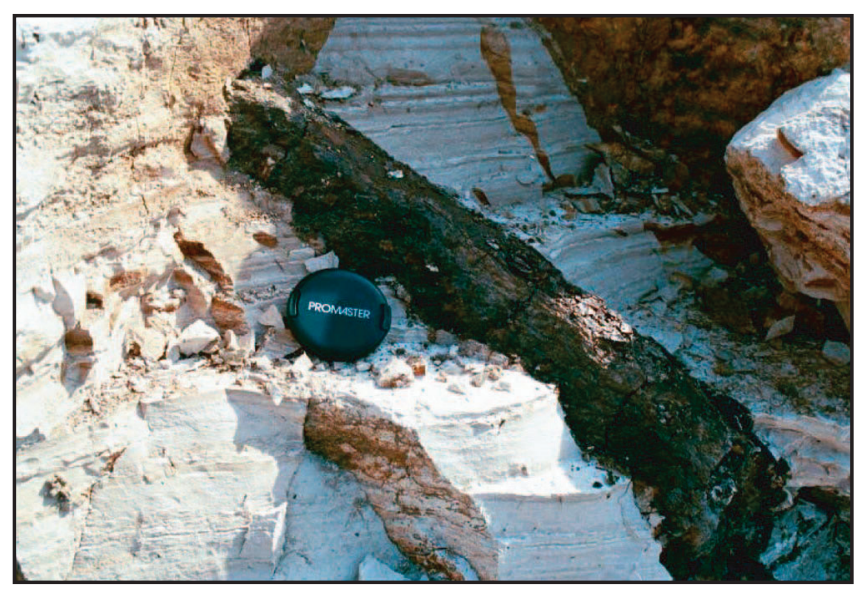

Figure 23. Vertebrate burrow cutting across Tierras Blancas diatomaceous mudstone bedding and filled with dark brown organic material at San José Toxi. Camera lens cap for scale.
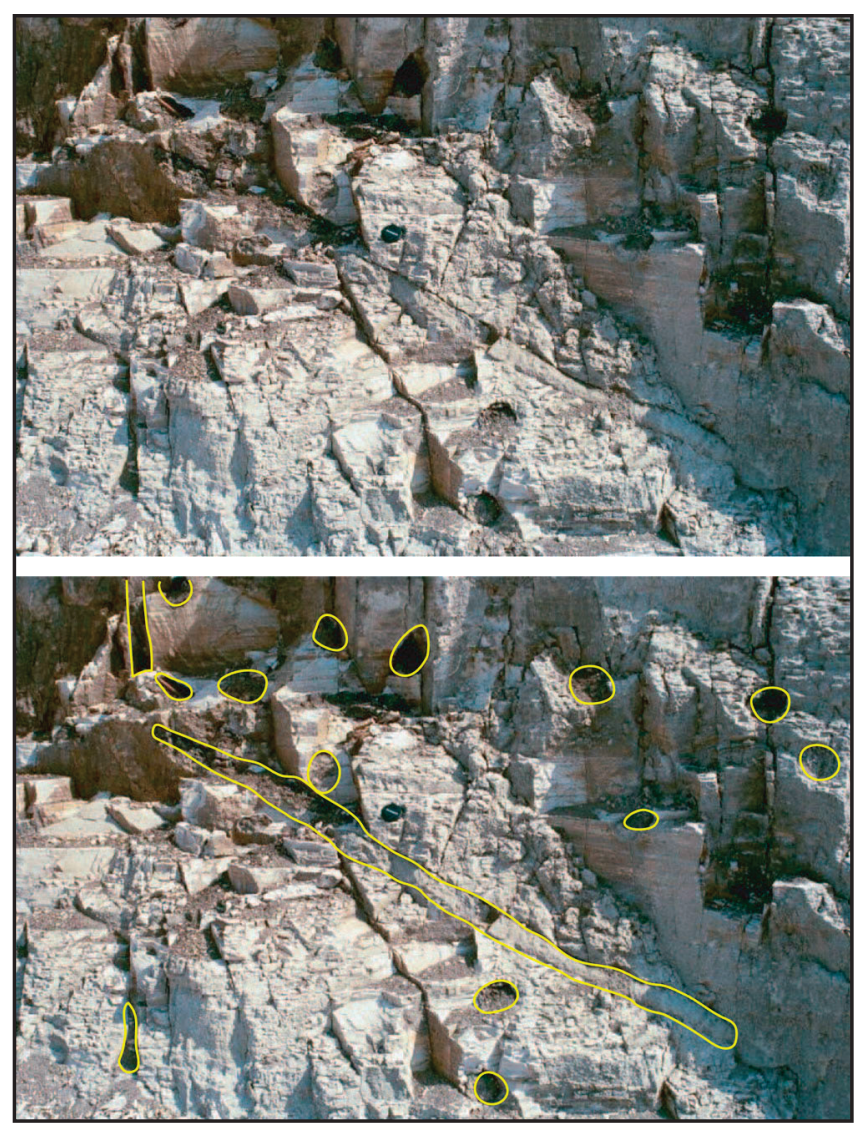

Figure 24. Both photos above are of the same view. The bottom photo highlights the vertebrate burrows in the Tierras Blancas diatomaceous mudstone. Note the long burrow that cuts diagonally across the center of the photograph. The lower portion of the burrow is filled with white material (diatomaceous mudstone sediment), and the upper portion of the burrow is filled with dark organic material. Camera lens cap for scale.

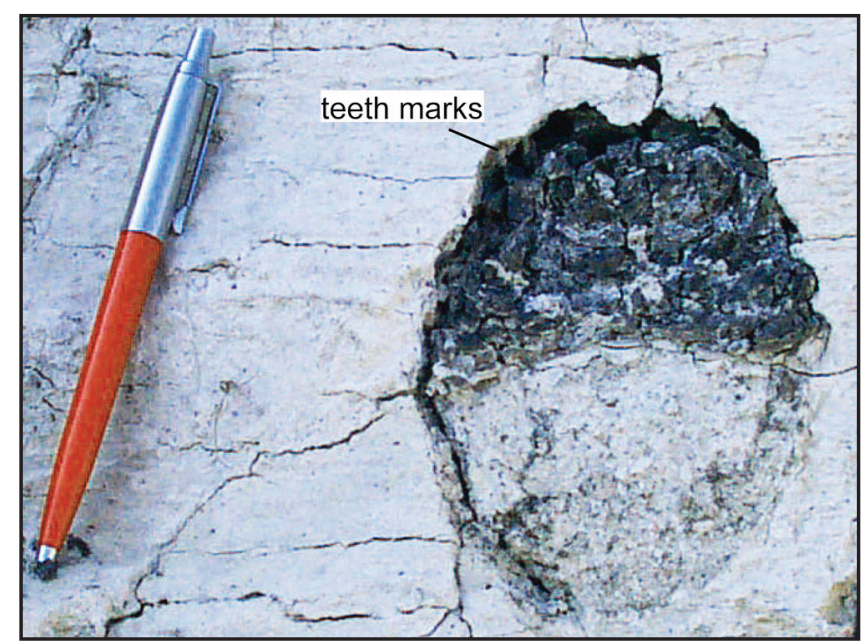

Figure 25. Vertical cross-sectional cut of a vertebrate burrow with diatomaceous mudstone sediment filling the lower half of the burrow and brown organic material filling the upper half. The small vertebrates (probably ground squirrels) used their teeth and/or claws to dig through the sediment, creating the cuspate edges of the burrow. Pen for scale.

the upper part (Figs. 24 and 25). The vertebrate burrows tend to increase in abundance upsection and also have increased abundance in certain localities (Figs. 24 and 26).

Diatoms identified in the lacustrine diatomaceous mudstone lithofacies of the Tierras Blancas beds include the following genera: Aulacoseira, Stephanodiscus, Staurosira, Cocconeis, Cymbella, Gomphonema, Rophalodia, and Synedra (Fig. 27). Planktonic genera (Aulacoseira and Stephanodiscus) dominate the diatom assemblage through most of the lacustrine section. Periphytic diatoms are sparse, and tycoplanktonic genera are

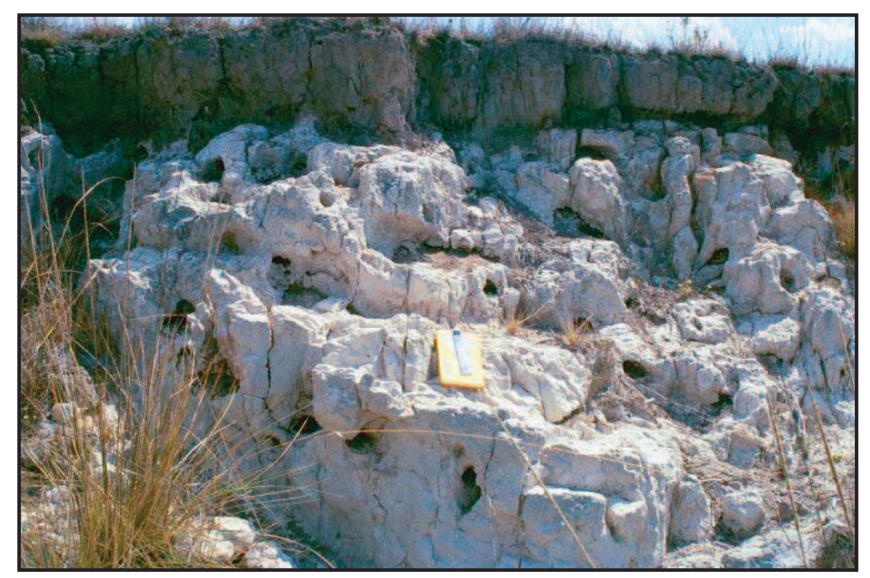

Figure 26. Photo showing density of vertebrate burrows in the Tierras Blancas diatomaceous mudstone. The abundance of vertebrate burrows in this outcrop is relatively high. Note the thin layer of Quaternary alluvium lying unconformably above the Tierras Blancas beds. Photograph was taken in the Las Arenas locality (see Fig. $3)$. Notebook with $15-\mathrm{cm}$ ruler for scale. 


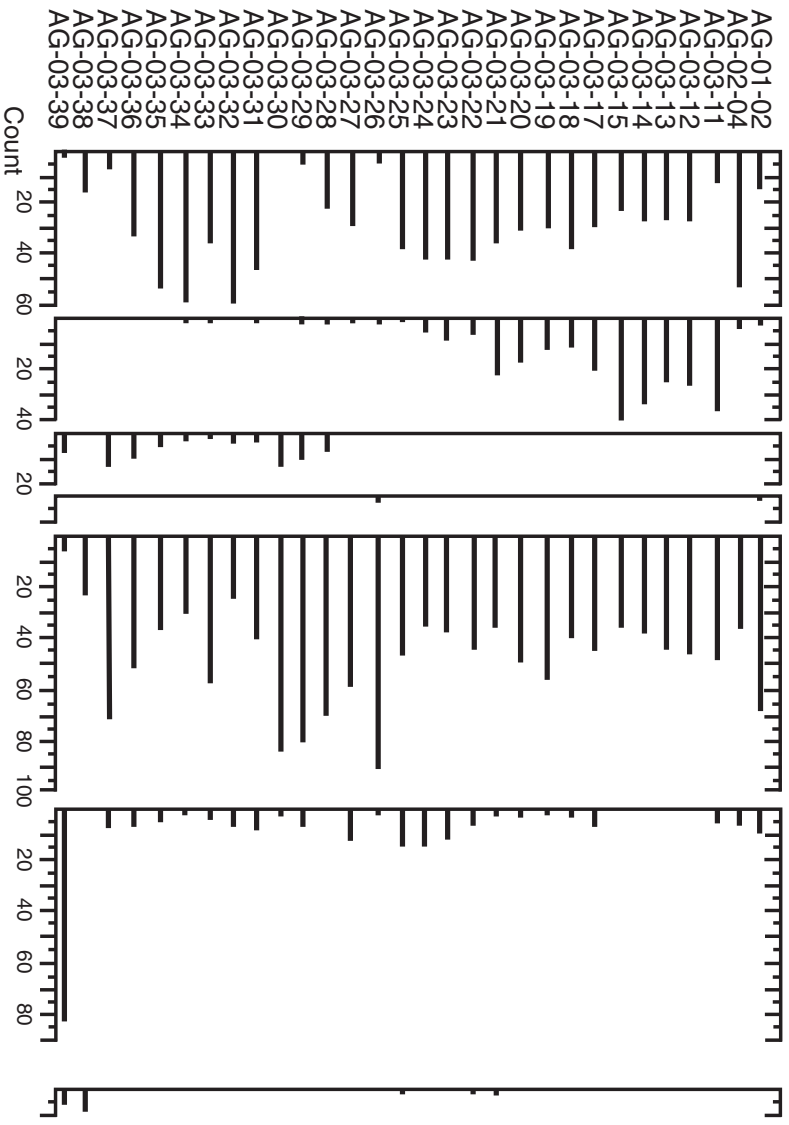

\section{$\infty$
$\frac{0}{3}$
$\frac{0}{D}$
$\frac{0}{\infty}$}

Aulacoseira ambigua

A. granulata var. angustissima

A. granulata

A. italica

Stephanodiscus excentricus

S. niagarae

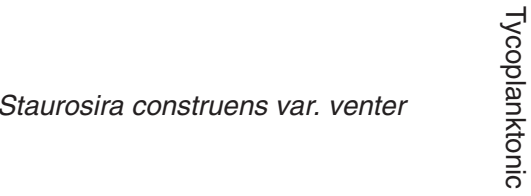

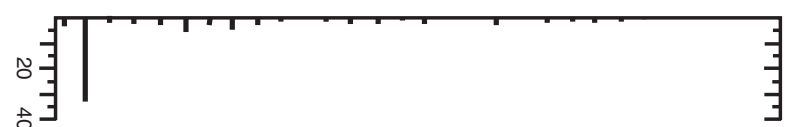

Cocconeis placentula var. placentula

Cymbella helmckei
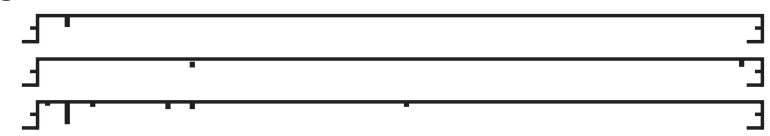

Gomphonema affine

Rophalodia gibba

舟

Synedra ulna

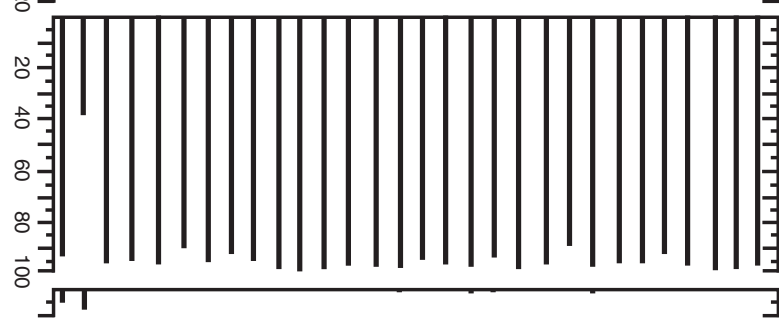

$\exists$ Tycoplanktonic

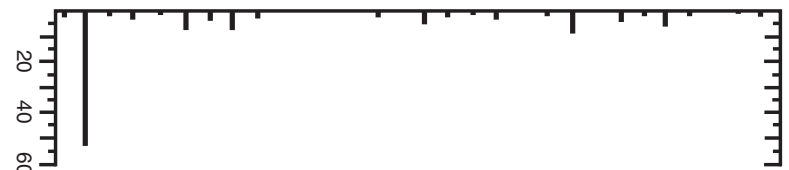

Planktonic

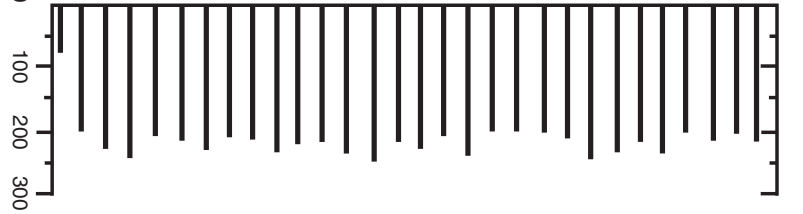

Periphytic

Total

Figure 27. Diatom assemblages from the Tierras Blancas diatomaceous mudstone lithofacies. The diagrams show counts of each species and totals of planktonic, tycoplanktonic, and periphytic taxa. 


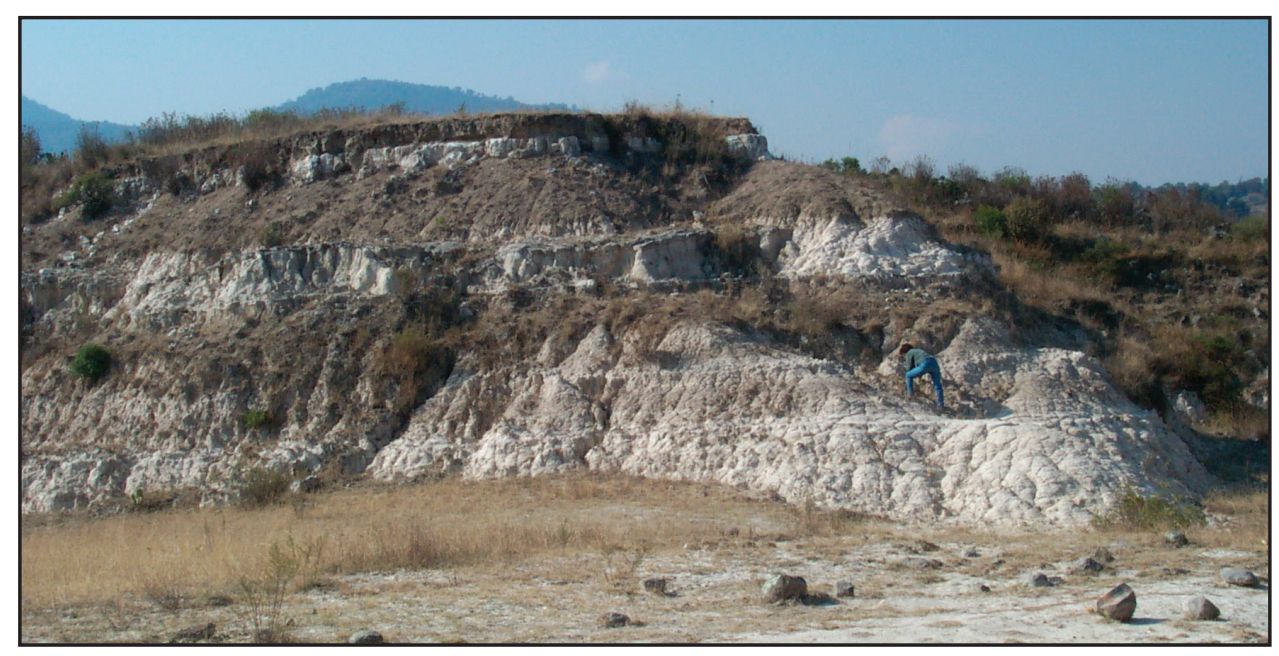

Figure 28. Tierras Blancas beds in the San Bartolo locality. The diatomaceous mudstone lithofacies (white) lies at the base of the outcrop and grades upward into the massive mudstone lithofacies (brown). A thin volcaniclastic sandstone bed (resistant bed) lies on top of the massive mudstone. A second sequence of diatomaceous mudstone, massive sandstone, diatomaceous mudstone, and resistant volcaniclastic makes up the upper half of the outcrop.

mostly absent. An exception is near the base of the diatomaceous mudstone (sample AG-03-38) where periphytic genera are slightly more abundant than planktonic diatoms and tycoplanktonic genera have their highest abundance.

The massive mudstone lithofacies lies conformably on top of, and in places interbedded with, the diatomaceous mudstone forming a gradational contact. It is a brown slope-forming unit (Fig. 28). The massive mudstone ranges in thickness from $>1 \mathrm{~m}$ to $5+\mathrm{m}$, and is horizontally bedded, except where it is tilted in the same orientation as the underlying diatomaceous mudstone.

Like the volcaniclastic sandstone lithofacies of the Lagunita beds, Tierras Blancas sandstones are volcaniclastic sandstones (Fisher, 1961). The volcaniclastic sandstone lithofacies is commonly interbedded with the diatomaceous mudstone and massive mudstone, usually forming a basal contact with the massive mudstone and an upper contact with the diatomaceous mudstone. These beds generally maintain the same thickness laterally, although a road cut in San Bartolo Lanzados exposes a volcaniclastic sandstone bed that has a channel structure (Fig. 29). The beds are thin $(5-30 \mathrm{~cm})$, black to dark gray in color, and laterally extensive. The sandstone is medium- to coarse-grained, moderately sorted, moderately cemented, and has angular to subangular grains. Volcanic lithic grains dominate the sand grain assemblages. Vitric volcanic lithic grains are the most abundant constituents and include colorless pumice and glass shards. Lathwork and microlitic volcanic lithic grains are a significant component of Tierras Blancas volcaniclastic sandstones and consist of a dark-colored glassy groundmass with plagioclase phenocrysts and/or visible plagioclase microlites. Monocrystalline grains, such as plagioclase, quartz, and Fe-Ti oxides, constitute a minor component of the grain assemblage. When plotted in a QFL (quartz-feldspar-lithics) ternary diagram (Fig. 20), the Tierras Blancas volcaniclastic sandstones plot in the undissected arc provenance subdivision of Dickinson et al. (1983). The volcaniclastic sandstone beds are normally graded. Along its irregular basal contact with the diatomaceous mudstone, white clay rip-up
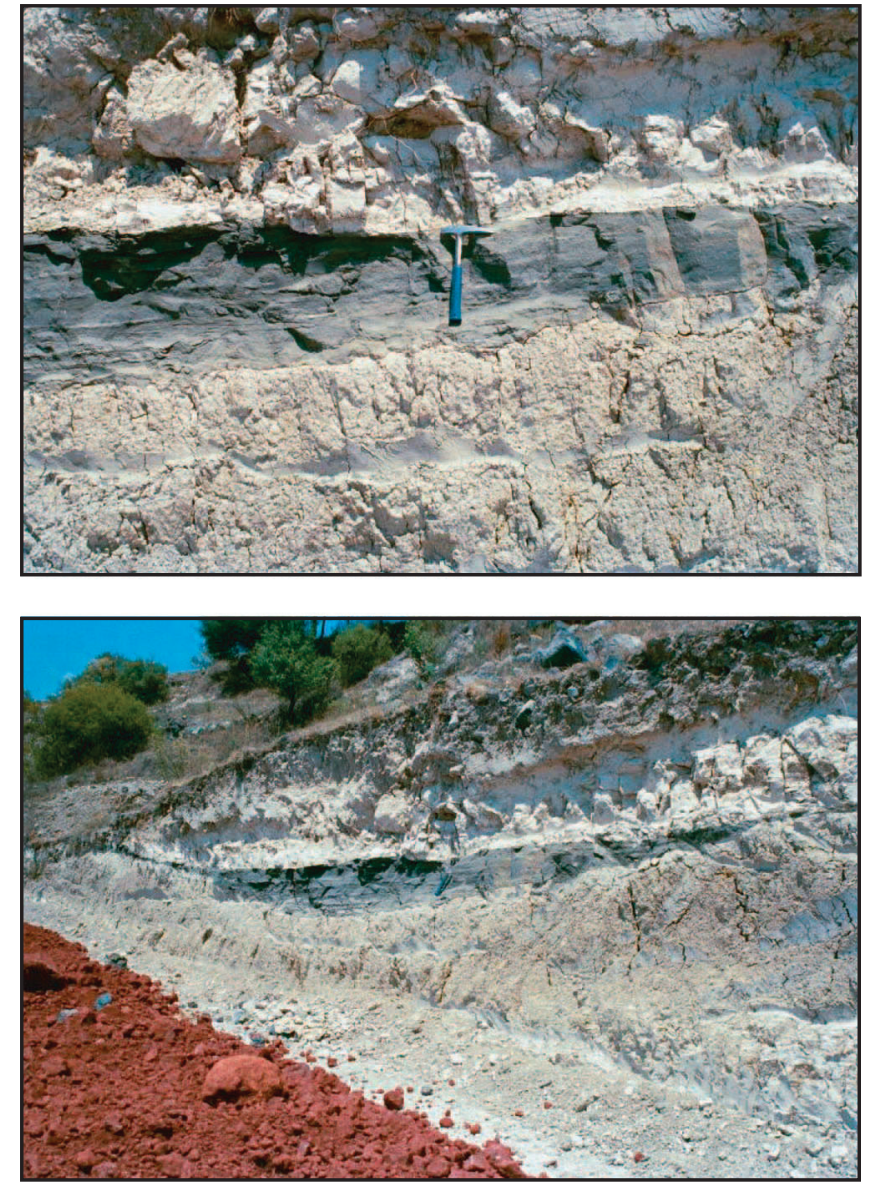

Figure 29. Photographs of the Tierras Blancas volcaniclastic sandstone bed along a road cut near the San Bartolo locality (see Fig. 3 ). The sandstone (gray) is interbedded with diatomaceous mudstone. The basal contact of the sandstone bed is sharp and irregular, indicating erosion of the underlying mudstone. The sandstone bed has a channel-like shape, pinching outward to a very thin bed. The channel shape indicates fluvial deposition, which interrupts lacustrine deposition of the diatomaceous mudstone. Hammer for scale. 


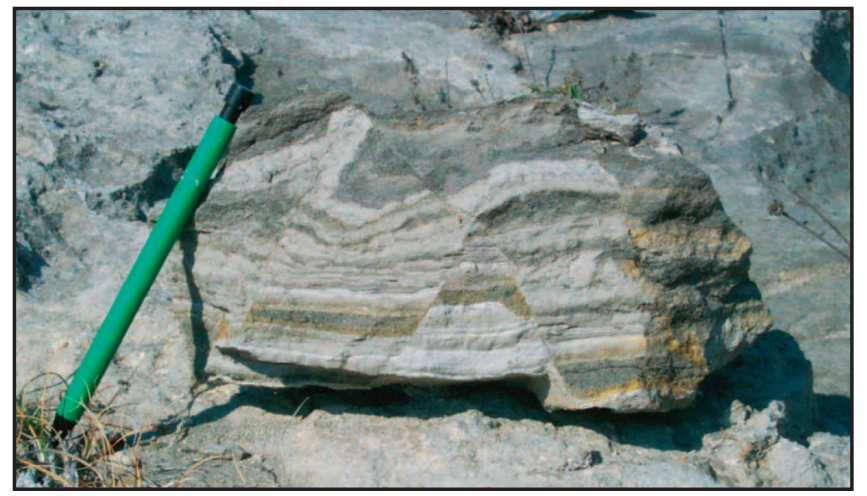

Figure 30. Centimeter-scale faulting and convolute bedding in a Tierras Blancas volcaniclastic sandstone bed at the Cementerio de San Bartolo locality. Pencil for scale.

clasts are common, and white clay interbeds occur within the sandstone (Fig. 30). The upper surface of Tierras Blancas volcaniclastic sandstone displays sedimentary tool marks (Fig. 31) likely created by the movement of objects in shallow water by waves or wind (Coe et al., 2010; Wetzel, 2013).

The Tierras Blancas beds generally show horizontal bedding lacking deformation, but deformed bedding also occurs in several outcrops of the Tierras Blancas beds. Where the Lagunita beds show relative deformation uniformity, the tilted bedding of the Tierras Blancas beds is relatively unsystematic. Dipping Tierras Blancas beds commonly are juxtaposed with horizontally bedded strata and display significantly different bedding attitudes over meter-scale distances (Figs. 32 and 33).
A stereoplot of poles to bedding of Tierras Blancas sandstones corresponds with the unsystematic deformation viewed in outcrops in that the stereoplot lacks a trend (Fig. 17), despite a limited number of points.

The pattern of deformed bedding of the Tierras Blancas beds shows similarity to slumped bedding or soft sediment deformation. In areas of slump-like deformation, the volcaniclastic sandstones show soft sediment deformation in the form of centimeterscale faults and convoluted bedding (Fig. 30). Quaternary lava flows always directly overlie the outcrops of deformed Tierras Blancas sediments, and two locations show overlying lava flows that mixed with underlying Tierras Blancas mudstone (Fig. 34). Tierras Blancas units commonly are not deformed where lava flows do not occur (Fig. 3). We conclude that the deformation seen in the Tierras Blancas beds are the result of lava flow emplacement onto wet, unconsolidated sediment.

\section{Late Pliocene-Pleistocene Volcanic Rocks (Tr, Ta)}

Several undated volcanic structures lie in the southeastern portion of the Acambay graben. A silicic lava dome, named the Cerro Santa Lucía by Norato-Cortez (1998; Fig. 6), lies along the western margin of the study area (Fig. 5) and is a parasitic lava dome to the inactive San Pedro stratovolcano (Norato-Cortez, 1998). Norato-Cortez (1998) described the Cerro Santa Lucía as part of a post-stratovolcano phase in the Acambay graben in which several dacitic and rhyolitic lava domes erupted.

The San Pedro stratovolcano was active during the early Pliocene (Norato-Cortez, 1998), and, therefore, the age of the Cerro Santa Lucía may be constrained to the late Pliocene and/ or early Pleistocene. Silicic lava flows associated with the Cerro

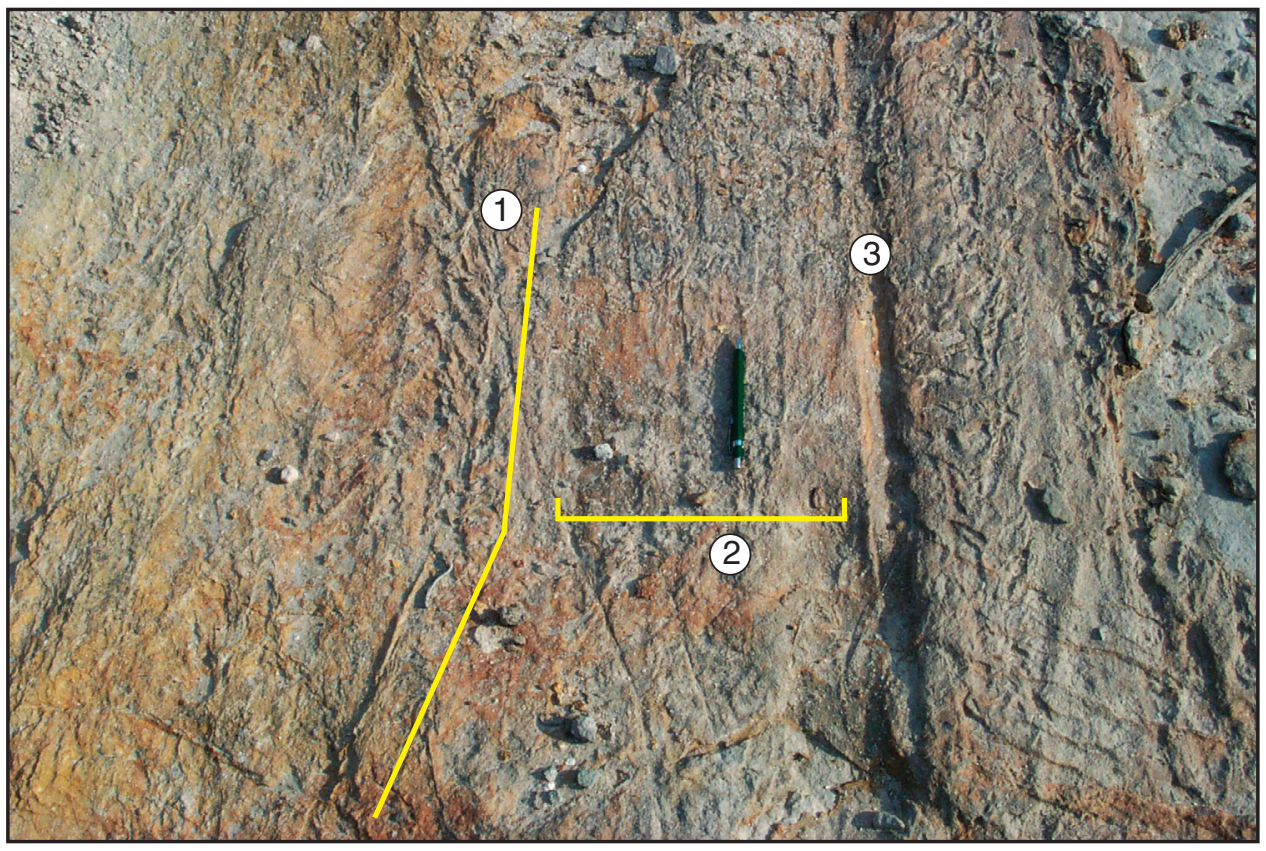

Figure 31. Tool marks on the upper contact of a Tierras Blancas volcaniclastic sandstone bed. The tool marks typically trend in a NNW-SSE direction and were caused by objects moved by waves probably in fairly shallow water. (1) tool mark or perhaps tilting mark (Wetzel, 2013) with feathered edges; (2) area of fine linear tool marks of uniform orientation; (3) large, deep linear tool mark, with perhaps a feather-like edge on it's right side. Photograph was taken in the San Bartolo locality. Pencil for scale. 

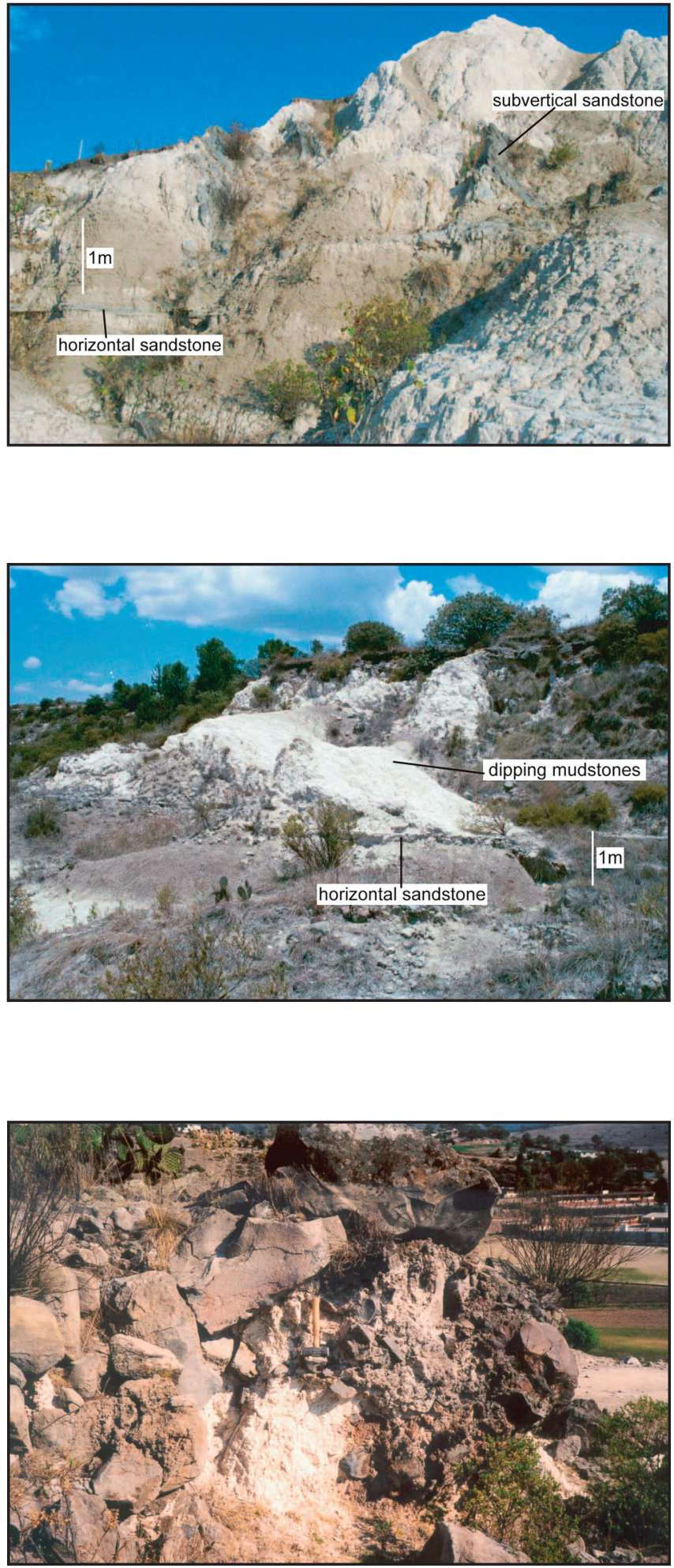

Figure 32. Deformed bedding of the Tierras Blancas section in the San Bartolo locality. On the right-hand side of the photograph, bedding is nearly vertical, while bedding on the left-hand side is nearly horizontal. The bedding orientations are best shown by the dark gray volcaniclastic sandstones. The white sediments are diatomaceous mudstones, and the light brown sediments are massive mudstones.

Figure 33. Deformed Tierras Blancas beds in the Las Casas locality. The white diatomaceous mudstones are dipping at $\sim 30-40^{\circ}$ to the right in the photo, while a thin $(15 \mathrm{~cm})$ dark gray volcaniclastic sandstone lying at the base of the diatomaceous mudstone is horizontal.

Figure 34. Basal breccia of Quaternary andesite lava (Qva) overlying Tierras Blancas diatomaceous mudstone in the San Bartolo locality. The andesite flow mixed with the underlying, unconsolidated mudstone during emplacement. Hammer for scale. 
Santa Lucía were sampled in three locations (Fig. 5) and include two dacites and one low-silica rhyolite (Fig. 7). These dacites and rhyolites have light gray groundmasses with $\sim 50 \%$ phenocrysts including plagioclase, quartz, biotite, and amphibole. The dacites and rhyolite are medium- to high-K and magnesian (Fig. 7). The dacite and rhyolite group plots in the volcanic arc region of the tectonomagmatic discrimination diagram of Pearce et al. (1984; Fig. 8). The volcanic rocks that were analyzed as part of this study show geochemical similarities to compositions reported by Sánchez-Rubio (1984) and Norato- Cortez (1998) for volcanic rocks in the Acambay graben.

An undated, poorly-exposed andesite lava flow (Ta on Fig. 5) lies in the west-central part of the study area. Its association with volcanic centers in the area is difficult to constrain due to poor exposure, but it likely erupted from the Cerro Santa Lucía or the San Pedro stratovolcano, based on its geographic proximity to these structures. Therefore, it is likely late Pliocene-Pleistocene in age, and appears to be younger than the Tierras Blancas beds and older than the Cementerio beds (Fig. 6).

Dacite and low-silica rhyolite lava flows, as well as additional minor andesite lavas, associated with Cerro Santa Lucia were sampled in several locations ( $\mathrm{Tr}$ on Fig. 5). The dacites and rhyolites have light gray groundmasses with abundant phenocrysts including plagioclase, quartz, biotite, and amphibole. These rocks are part of a medium- $\mathrm{K}_{2} \mathrm{O}$ suite (Figs. 7 and 35) and are similar to those reported by Sánchez-Rubio (1984) and Norato-Cortez (1998) for volcanic rocks from the Acambay graben. Unlike the older peralkaline rhyolite tuffs, these locally
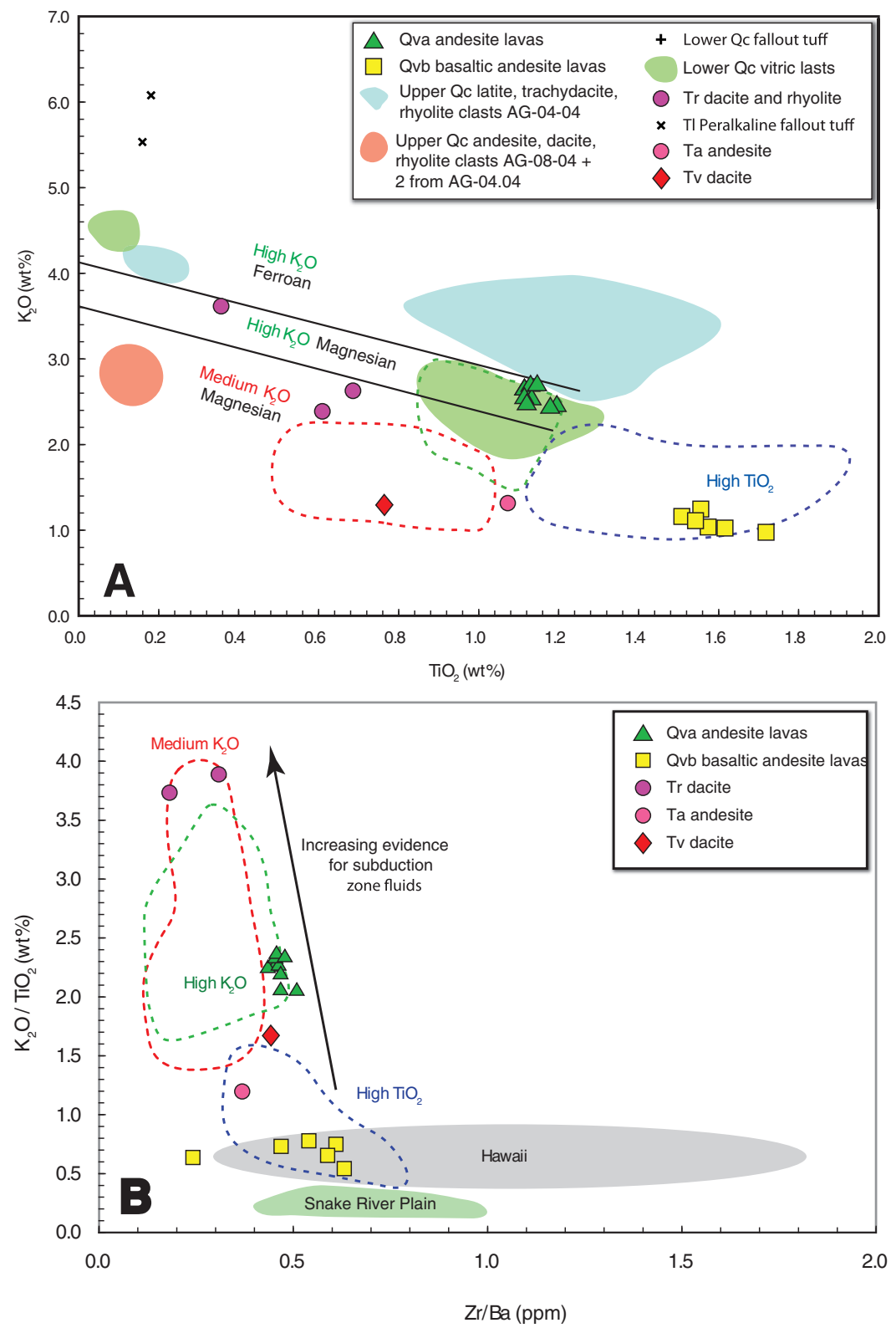

Figure 35. Classification of volcanic rock series in the Acambay graben. Dotted lines enclose fields from Blatter et al. (2007). (A) On this $\mathrm{K}_{2} \mathrm{O}-\mathrm{TiO}_{2}$ variation diagram, we have distinguished four principal types among the lavas, tuffs, and volcanic clasts here: medium $\mathrm{K}_{2} \mathrm{O}$, high $\mathrm{K}_{2} \mathrm{O}$, and high $\mathrm{TiO}_{2}$ all of which are magnesian (Fig. 7) and a separate ferroan high- $\mathrm{K}_{2} \mathrm{O}$ series. The oldest lavas are medium $\mathrm{K}_{2} \mathrm{O}$ ( $\mathrm{Tv}$ and $\mathrm{Ta}$ ). Younger rocks and sandstone grains include representatives of all categories. (B) Plot of $\mathrm{Zr} / \mathrm{Ba}$ versus $\mathrm{K}_{2} \mathrm{O} / \mathrm{TiO}_{2}$ for the mafic and intermediate rocks shows that they have higher LIL $(\mathrm{Ba}, \mathrm{K})$ to HFS (Zr, Ti) element ratios than intraplate basalts like those from Hawaii or the Snake River Plain (Christiansen and McCurry, 2008). The high $\mathrm{TiO}_{2}$ basaltic andesites have the weakest subduction zone signature and some overlap with Hawaiian basalts. Trace element models and petrography show that the high- $\mathrm{K}_{2} \mathrm{O}$ lavas are crustally contaminated versions of the high- $\mathrm{TiO}_{2}$ lavas. 


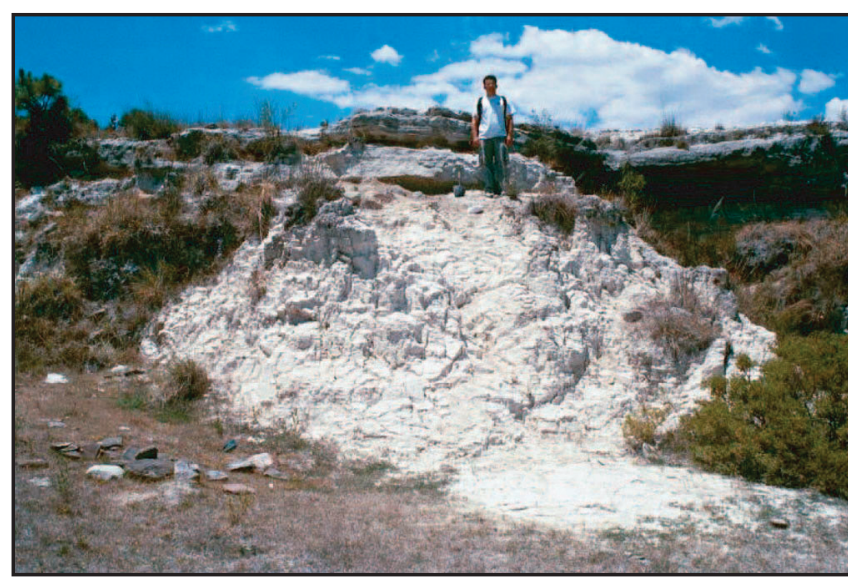

Figure 36. Resistant Cementerio beds (gray) capping Tierras Blancas beds (white) in the Línea de Teléfono locality. In this photograph, tuffaceous sandstones comprise most of the Cementerio beds with a volcanic ash bed in lowest part. The exposed Tierras Blancas beds are relatively thin here.

erupted lavas are magnesian and calcic and have most of the other characteristics of a volcanic arc series (Fig. 8). Their trace element patterns have deep negative $\mathrm{Nb}$ and $\mathrm{Ti}$ anomalies and strong enrichments of the large ion lithophile elements like $\mathrm{Rb}$, $\mathrm{Ba}$, and $\mathrm{Pb}$. They have low $\mathrm{Rb} / \mathrm{Ba}$ ratios, high $\mathrm{Sr}$ (except for the rhyolite), and modest $\mathrm{Pb}$ peaks (Fig. 9). The rhyolite has small negative $\mathrm{Sr}$ and $\mathrm{P}$ anomalies - probably the result of significant feldspar and apatite fractionation (Fig. 8).

This older Pliocene-Pleistocene suite shares many similarities with the Quaternary medium- $\mathrm{K}_{2} \mathrm{O}$ suite found near the modern arc front (Fig. 9). However, $\mathrm{Cr}, \mathrm{Mg}$, and $\mathrm{Ni}$ are distinctly

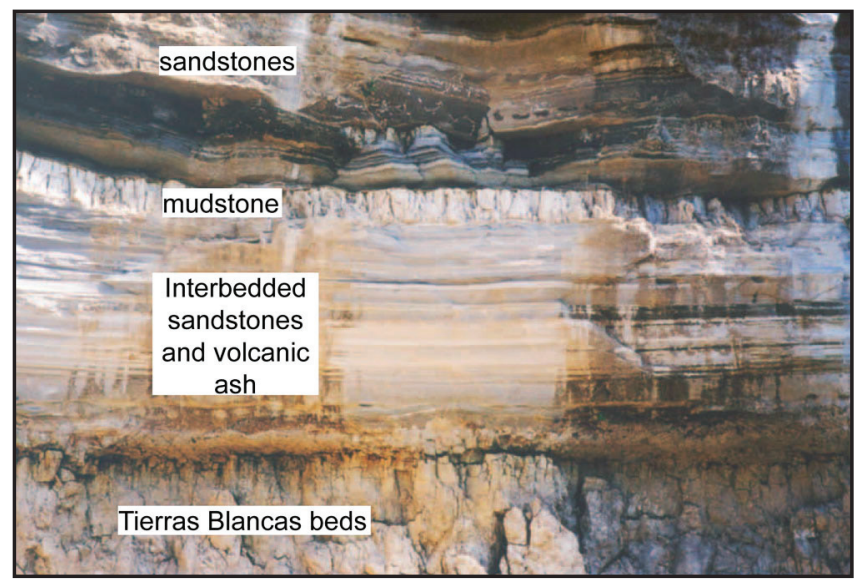

Figure 37. Cementerio beds lying unconformably on top of the Tierras Blancas beds in the Cementerio de San Bartolo locality. Note the interbedded character of the sandstones, mudstones, and volcanic ash beds of the Cementerio section. The volcanic ash (AG2002-04) was collected from this locality. The total thickness of the sediments in the photograph is $\sim 3 \mathrm{~m}$. lower than arc-front lavas and $\mathrm{Al}$ is higher (Blatter et al., 2007). The andesites erupted at what may have been the front of the volcanic arc. Ferrari et al. (2012; their fig. 13), for example, concluded that the volcanic front was near Acambay 6-2 Ma before it migrated southward to its modern position.

\section{Quaternary}

\section{Pleistocene Cementerio Beds (Qao)}

Unconformably overlying the Tierras Blancas beds are the Cementerio beds (Fig. 6), which include tuffaceous sandstone, mudstone, and tuff lithofacies (ash-sized pyroclastic fall). The Cementerio beds have an erosional contact with the underlying Tierras Blancas beds and range in thickness from 1 to $4 \mathrm{~m}$ (Figs. 36-38). The Cementerio beds have not been mapped separately due to limited thickness and vertical exposures in outcrop, but are

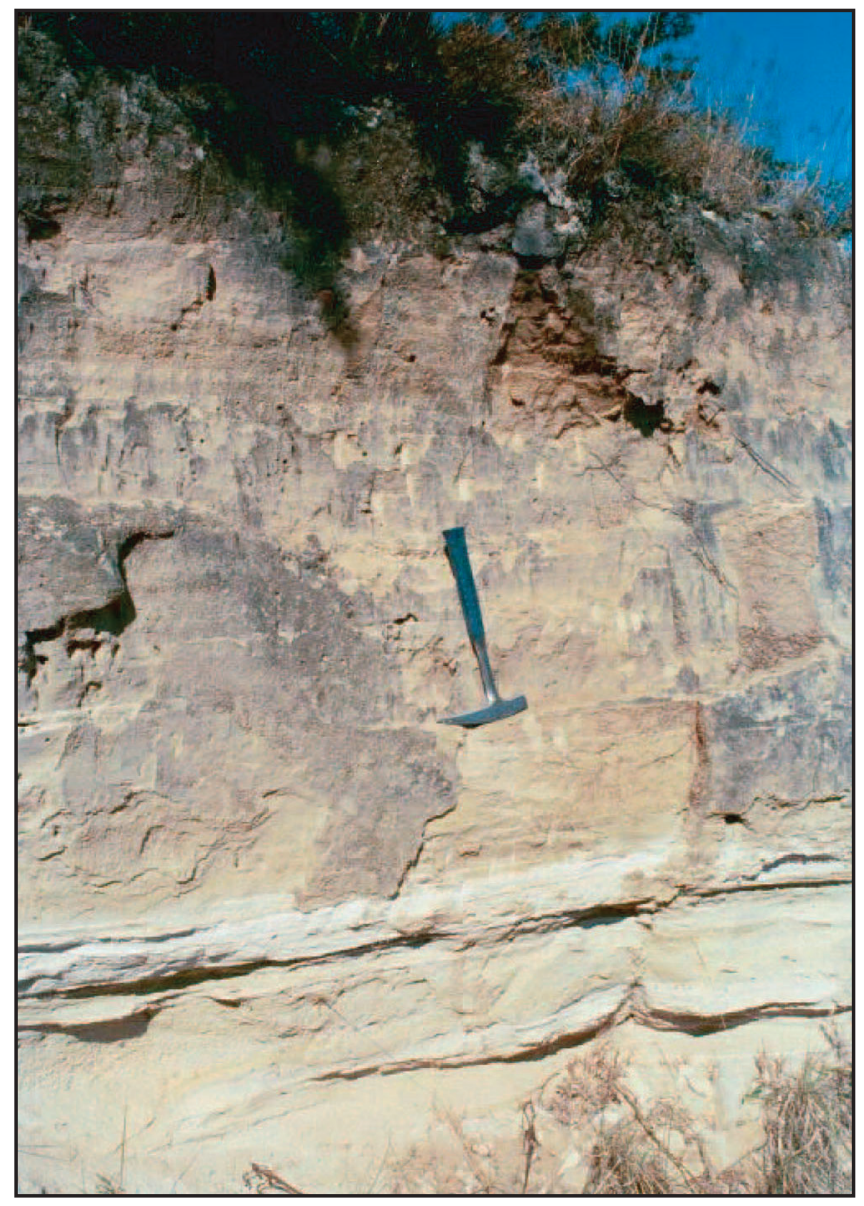

Figure 38. Tuffaceous sandstone (tan to buff color) and volcanic ash (white) from the Cementerio beds in the Los Espejos locality. The volcanic ash yielded a zircon fission-track age of $1.20 \pm$ $0.13 \mathrm{Ma}$ (Mercer et al., 2002). The Cementerio-Tierras Blancas contact (not seen in photo) lies less than one meter below the volcanic ash bed. Hammer for scale. 
included in the older Quaternary alluvium (Qao) on the geologic map (Fig. 5).

While the Cementerio beds are Quaternary in age, they are distinct from other Quaternary sediments because of their tuffaceous character. The Cementerio beds have not yielded any mammal fossils but are important because one ash bed has yielded a zircon fission-track age of $1.20 \pm 0.13 \mathrm{Ma}$ (Mercer et al., 2002; Figs. 19 and 36).

The mudstone lithofacies in this unit is limited in its extent and is found in only three localities. The mudstones are interbedded with tuffaceous sandstones and commonly have thicknesses of less than a meter (Fig. 37). The mudstones are massive, white or brown, contain thin $(<1 \mathrm{~cm}$ in width) root traces, and are horizontally bedded.

Like the Lagunita and Tierras Blancas beds, the sandstones of the Cementerio beds are volcaniclastic sandstones, according to the classification of Fisher (1961). To differentiate volcaniclastic sandstones that are mostly composed of pyroclasts that show little textural modification, Critelli et al. (2002) use the term "tuffaceous sandstones." Therefore, the Cementerio sandstones are described here as tuffaceous sandstones in order to emphasize the relatively large component of sand-sized pyroclasts in the Cementerio sandstones as compared to the Lagunita and Tierras Blancas volcaniclastic sandstones.

The tuffaceous sandstone lithofacies is the most prominent and abundant of the Cementerio lithofacies. It lies unconformably on top of the Tierras Blancas beds and is a cliff-forming unit that often caps the outcrops of Pliocene-Pleistocene sediments (Figs. 36-38). The tuffaceous sandstone is generally thickly bedded and interbedded with thin tuffs and mudstones (Fig. 38), although some sections of the Cementerio beds have thinly bedded tuffaceous sandstones interbedded with thinly bedded mudstones (Fig. 37). The tuffaceous sandstone is tan to buff to gray in color, medium- to coarse-grained, moderately to poorly sorted, poorly cemented by zeolites, and contains subangular to subrounded grains. Volcanic lithic grains strongly dominate the sand grain assemblages of the Cementerio sandstones. Vitric volcanic lithic grains are the most abundant volcanic lithic grain, while other types of volcanic lithic grains constitute a minor component of the grain assemblage (Fig. 20).

The Cementerio sandstones contain a significant component of plagioclase feldspar but little quartz, potassium feldspar, and other monocrystalline minerals. The Cementerio sandstones plot in the undissected arc provenance subdivision of Dickinson et al. (1983; Fig. 20). Lenses of gravel-sized pumice are common (Fig. 39 ), and sand grains are generally volcanic lithics. Planar lamination, trough cross-lamination $(5-10 \mathrm{~cm})$, and normally graded bedding are common. Where tuffaceous sandstones are interbedded with mudstones, soft sediment deformation is present along the erosional contacts between the sandstones and mudstones.

Electron microprobe analyses of vitric volcanic lithic grains of two samples (AG-03-01 and AG-06-01) from the basal tuffaceous Cementerio sandstone bed show a single distinct grouping of high-K, ferroan rhyolite (Fig. 7). On geochemical variation diagrams, these high- $\mathrm{SiO}_{2}$ rhyolites consistently show a tight grouping (Fig. 40).

In contrast, samples that were collected from upper tuffaceous sandstones of the Cementerio beds (AG-08-01 and AG-0404) have vitric volcanic lithic grains with much broader ranges in compositions, varying from dacite to rhyolite for AG-08-01 and from trachydacite to rhyolite for AG-04-04 (Figs. 7 and 40). In sample AG-08-01, grain compositions are dominantly medium$\mathrm{K}$ and magnesian (Fig. 7), while vitric grains in sample AG-0404 are high-K and dominantly ferroan (Fig. 7). Analyses of lathwork and microlitic volcanic lithic grains for sample AG-04-04 are typically more mafic than the glassy grains, varying from andesitic to trachydacitic (Fig. 7) and show a relatively broad range on variation diagrams (Fig. 40). All grains from this sample are dominantly high-K and ferroan (Fig. 7). Volcanic lithic grain compositions from the upper Cementerio sandstones are very similar to volcanic rocks associated with the nearby Amealco caldera (Aguirre-Díaz and McDowell, 2000; Fig. 3).

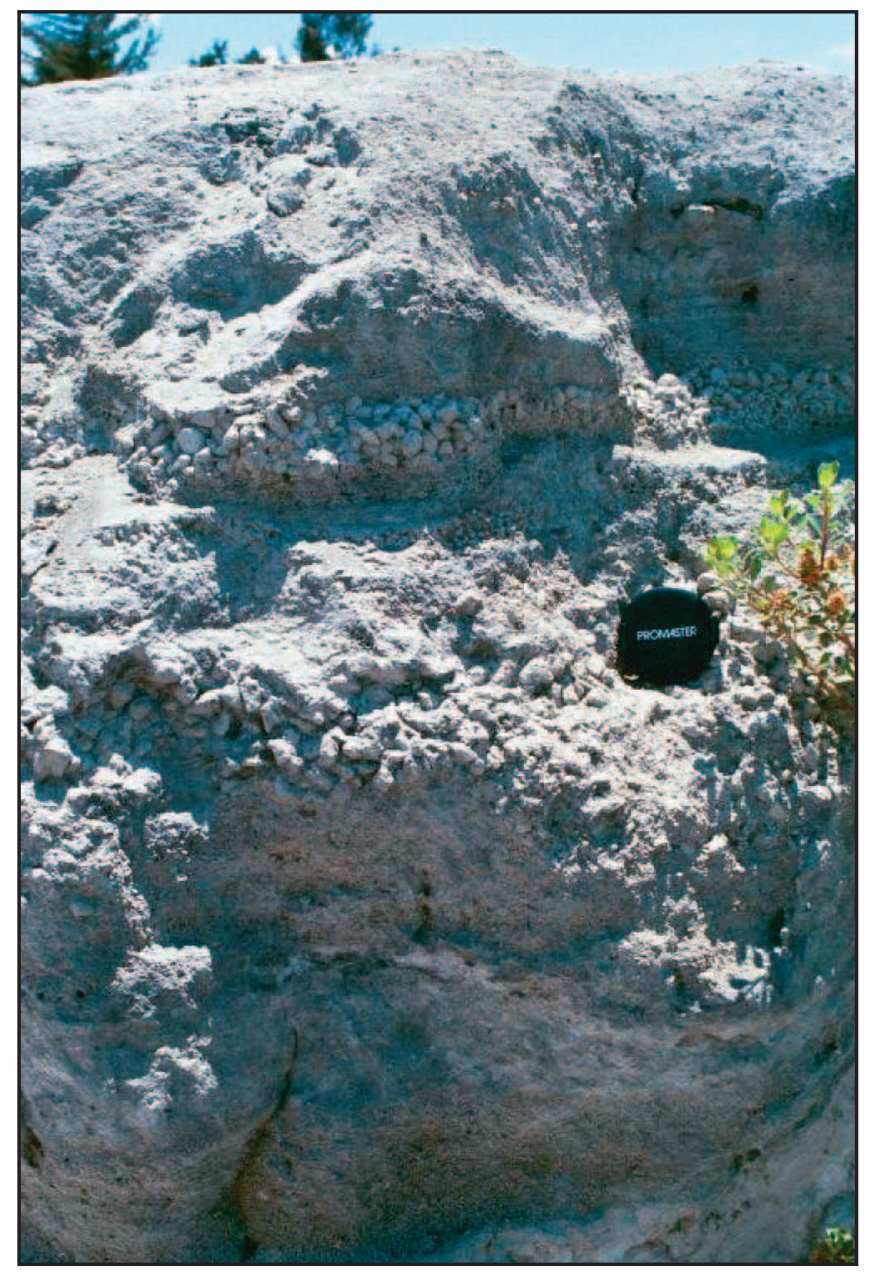

Figure 39. Coarse-grained tuffaceous sandstone from the Cementerio beds in the San Bartolo locality. Note the lenses of gravel-sized pumice throughout the sandstone. Camera lens cap for scale. 

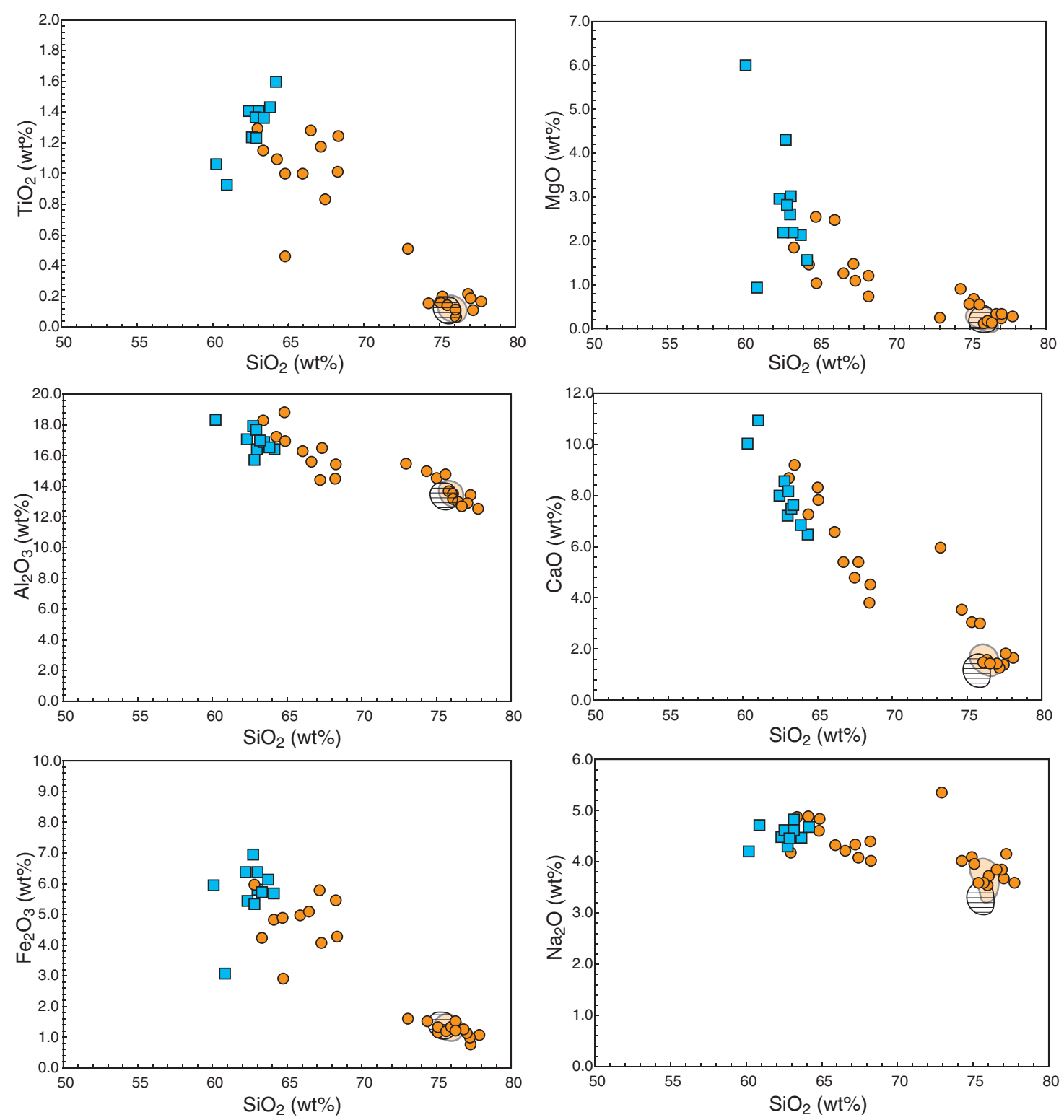

$\square$ Lathwork and microlitic grains from upper Cementario tuffaceous sandstone (AG-04-04)

- Vitric grains from upper Cementerio tuffaceous sandstones (AG-08-01 \& AG-04-04)

Vitric grains from the basal Cementerio tuffaceous sandstone (AG-03-01 \& AG-06-01)

Cementerio tuff

Figure 40. Silica variation diagrams for volcanic lithic grains in Cementerio sandstone as determined by electron microprobe analysis compared to Cementerio tuff bed analyzed by X-ray fluorescence. 
The tuff lithofacies crops out in four localities and is interbedded with tuffaceous sandstones forming gradational contacts (Figs. 36-38). The tuff ranges in thickness from 1 to $10 \mathrm{~cm}$ and extends laterally through an outcrop, where present. This unit is a distal pyroclastic fall tuff with white to light gray, poorly consolidated, ash-sized grains consisting of $>90 \%$ glass. Three samples (MX-2000-06, AG-2002-04, and AG-2002-08) were collected in separate localities from tuff units that lie $\sim 0.5-1.0 \mathrm{~m}$ above the basal contact of the Cementerio beds. The glass fractions of the tuff samples are rhyolitic in composition (Fig. 7). These three analyses are high-K, ferroan (Fig. 7), and plot closely in all variation diagrams (Fig. 15). In addition, because of relatively low $\mathrm{Nb}$ content these tuffs plot in the volcanic arc region of the Pearce discrimination diagram (Fig. 8). Based on similarities in composition and stratigraphy, these tuff samples represent one tuff unit. This rhyolite tuff is not peralkaline like the Pliocene tuff in the Lagunita beds, but is a normal arc-type rhyolite with higher $\mathrm{Al}, \mathrm{Ca}, \mathrm{Mg}, \mathrm{P}, \mathrm{Sr}, \mathrm{Ba}$ and lower $\mathrm{K}, \mathrm{Fe}, \mathrm{Nb}, \mathrm{Zr}, \mathrm{Zn}, \mathrm{Ga}, \mathrm{Y}$, $\mathrm{Pb}$, Th, $\mathrm{U}$ than the older tuff. A zircon fission track age of $1.2 \pm$ 0.13 Ma was obtained from this tuff (Fig. 19). The eruptive source of the tuff is unknown but it might have erupted from the local San Pedro volcanic complex. Moreover, the vitric grains in tuffaceous sandstones (AG-03-01 and AG-06-01) collected adjacent to the tuff are indistinguishable and must be derived from the fallout tuff (Fig. 40). The only perceptible difference is that the vitric grains have slightly higher $\mathrm{Na}_{2} \mathrm{O}$ than the tuff, but this could be explained by analytical differences since the vitric grains were analyzed by electron microprobe and the tuff was analyzed by X-ray fluorescence.

Overlying the Cementerio beds, but not distinguished as a separate unit on the map, are layers of older Quaternary alluvium and colluvium that sit above the current drainage and have been somewhat dissected by it (Figs. 5 and 6).

\section{High $\mathrm{TiO}_{2}$ Basaltic Andesites ( $\left.Q v b\right)$}

Lava flows and scoria cones in the northern part of the study area (Fig. 5) are associated with lavas that were named the Basalto Los Metates by Sánchez-Rubio (1984). These lava flows are associated with small scoria cones in the northeastern part of the study area (Fig. 41). Tentatively assigned a Pliocene age by Sánchez-Rubio (1984), Aguirre-Díaz et al. (2000) reported paleomagnetic results to correlate the Basalto Los Metates with the Matuyama chron (2.58-0.78 Ma; Cande and Kent, 1995). The lava flows lie stratigraphically above the 1.2 Ma Cementerio beds in at least one measured section (Línea de Teléfono, section TE on Fig. 5). Therefore, the age of these lava flows must be constrained to the younger portion of the Matuyama chron (1.1$0.78 \mathrm{Ma})$. These mafic lava flows were sampled in six locations (Fig. 5) and are basaltic andesitic in composition (Fig. 7). These basaltic andesites commonly have gray to dark gray groundmasses with $<5 \%$ plagioclase and pyroxene phenocrysts. They are medium-K and magnesian (Fig. 7) with high Ba/Nb (Fig. 8).

The Quaternary basaltic andesites are somewhat similar to the older lavas associated with Cerro Santa Lucia (units Tr and Ta) in that they are medium- $\mathrm{K}_{2} \mathrm{O}$, magnesian, calcic and have similar trace element patterns with low $\mathrm{Rb} / \mathrm{Ba}$ ratios, lesser enrichments of $\mathrm{Rb}$ and $\mathrm{Ba}, \mathrm{LREE}, \mathrm{Pb}$, and $\mathrm{Zr}$. The most distinctive characteristic of the Quaternary basaltic andesite is the high concentration of $\mathrm{TiO}_{2}$, which exceeds $1.4 \%$ (Fig. 15 and Table 1B). Compared with the other intermediate composition lavas (Qva) in the graben, their trace element patterns are less spiky with only small negative anomalies for $\mathrm{Ti}$ and almost no anomalies for $\mathrm{Sr}, \mathrm{Pb}$, or



Figure 41. Looking southwest from the La Cascada locality, basaltic andesite scoria cones and lava flows dominate the east-central part of the map area (see Fig. 5). The La Cascada locality has the thickest exposure of Lagunita beds (see Fig. 12). 


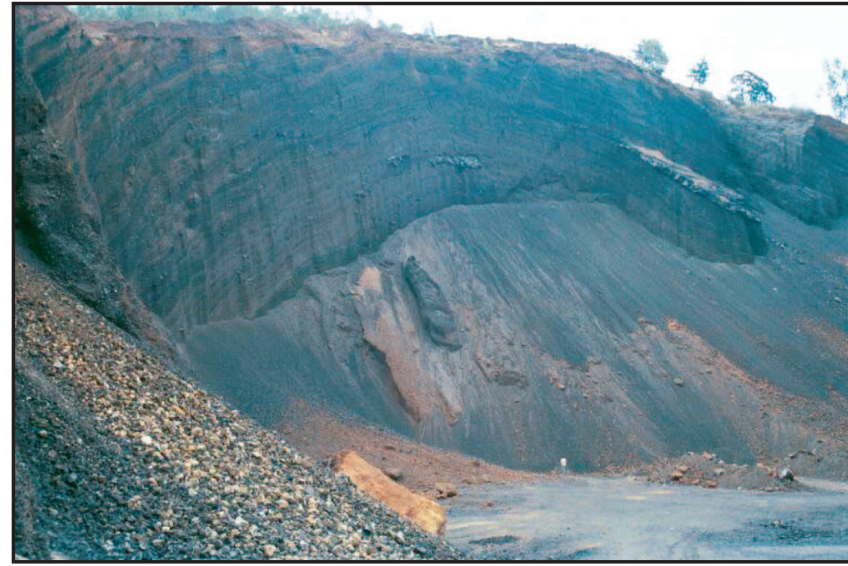

Figure 42. Quarry in an andesitic scoria cone in the footwall of the Pastores fault in the southern part of the map area (see Figs. 3 and 40 ). Quarry cut is $\sim 20 \mathrm{~m}$ high.

P. The lack of a phosphorus anomaly implies that they have not fractionated much apatite, consistent with their mafic compositions, but the other small anomalies must be source related and imply that less subduction-zone fluid was involved in their genesis. This is consistent with their lack of hydrous phases and the presence of plagioclase-all features which suggest a relatively low $\mathrm{H}_{2} \mathrm{O}$ content, estimated to be $<1.5 \%$ by Blatter et al. (2007). Blatter et al. (2001) and Blatter et al. (2007) have found that these high- $\mathrm{TiO}_{2}$ basaltic andesites are fairly common behind the active volcanic front in this part of Mexico.

\section{High $\mathrm{K}_{2} \mathrm{O}$ Andesites (Qva)}

Andesite lava flows (Qva) crop out in the southern part of the study area (Fig. 5) and are associated with scoria cones along the Pastores fault (Figs. 42 and 43). Suter et al. (1995) reported an ${ }^{40} \mathrm{Ar} /{ }^{39} \mathrm{Ar}$ age of $0.4 \pm 0.1 \mathrm{Ma}$ from these flows (Fig. 6). The andesites have dark gray to black groundmasses with 5\%-10\% plagioclase phenocrysts and sparse pyroxene. The andesitic lavas also have abundant xenocrysts of quartz and partially disaggregated clots of glassy feldspar, quartz, and biotite. The felsic inclusions are medium grained and reach to as much as $1 \mathrm{~cm}$ across. We interpret these to be the result of mixing with silicic magma or partial digestion of granitic xenoliths.

The andesites are distinctly more potassic than the basaltic andesites and straddle the dividing line between the mediumand high- $\mathrm{K}_{2} \mathrm{O}$ series (Fig. 7); to distinguish these andesites from the older medium- $\mathrm{K}_{2} \mathrm{O}$ andesites (unit Ta) and basaltic andesites (Qvb) we have called them high- $\mathrm{K}_{2} \mathrm{O}$ andesites.

Like the other locally erupted lava flows (and unlike the clasts in the Cementerio beds) the high- $\mathrm{K}_{2} \mathrm{O}$ andesites are magnesian. Compared to the older medium- $\mathrm{K}_{2} \mathrm{O}$ andesites (Ta), Qva andesite lavas have lower $\mathrm{CaO}$, and distinctly higher $\mathrm{P}_{2} \mathrm{O}_{5}$ at similar silica concentrations (Fig. 15). Another distinctive characteristic is their rather low concentrations of $\mathrm{Al}_{2} \mathrm{O}_{3}$, which average $\sim 16 \mathrm{wt} \%$. The high- $\mathrm{K}_{2} \mathrm{O}$ andesites also have high concentrations of compatible elements (e.g., $\mathrm{Cr}, \mathrm{Ni}, \mathrm{Mg}, \mathrm{Cu}$ ) compared to the medium- $\mathrm{K}_{2} \mathrm{O}$ andesites. Trace element patterns for these young andesites are very spiky with high concentrations of large ion lithophile elements (LILE), particularly $\mathrm{Rb}, \mathrm{Ba}$, and $\mathrm{K}$ when compared to the medium- $\mathrm{K}_{2} \mathrm{O}$ and high- $\mathrm{TiO}_{2}$ lavas (Fig. 9). In addition, $\mathrm{Pb} / \mathrm{Ce}$ and $\mathrm{Ba} / \mathrm{Nb}$ (Fig. 8) ratios are high. $\mathrm{Rb} / \mathrm{Ba}$ ratios are also high (Fig. 9), a feature unusual for andesites. Negative Sr-anomalies are consistent with a long history of plagioclase fractionation before eruption.

Although the high $-\mathrm{K}_{2} \mathrm{O}$ andesites in the Acambay area plot with the high- $\mathrm{K}_{2} \mathrm{O}$ lavas of Blatter et al. (2007) in terms of $\mathrm{K}_{2} \mathrm{O}$ versus $\mathrm{SiO}_{2}$ and $\mathrm{K}_{2} \mathrm{O} / \mathrm{TiO}_{2}$ ratios (Fig. 35), they are distinct from them in several ways. Perhaps most importantly the andesites here all contain plagioclase phenocrysts; apparently these pyroxene

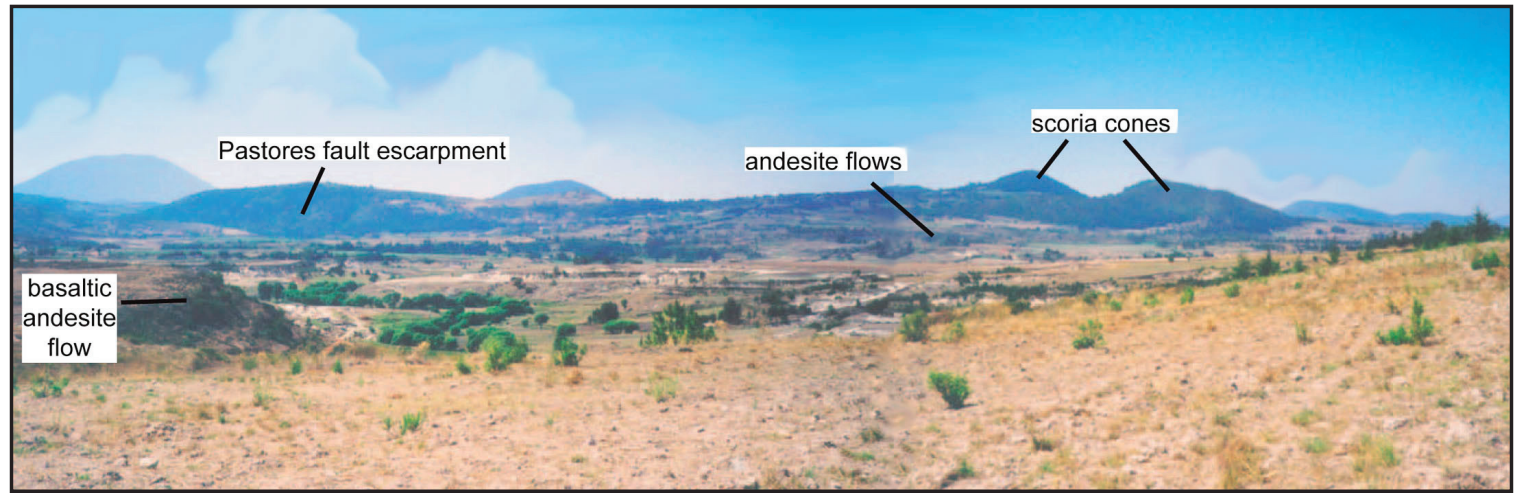

Figure 43. Looking south-southwest toward the field area in the southeastern Acambay graben. The photograph was taken from the north-central part of the field area. The Pastores fault forms the ridge along the horizon with a large escarpment (150 $\mathrm{m}$ high) to the left-hand side of the photograph (as marked). The Pastores fault forms a gradual rise toward the righthand side of the photograph where andesite flows and associated scoria cones obscure fault scarps. Lava flows near these scoria cones have yielded an ${ }^{40} \mathrm{Ar} /{ }^{39} \mathrm{Ar}$ age of $0.4 \pm 0.1 \mathrm{Ma}$ (Suter et al., 1995). A basaltic andesite lava flow crops out in the left hand foreground. Fossiliferous lacustrine sediments lie in the low-lying areas in the middle part of the photograph. 
andesites are not as hydrous as the plagioclase-free high- $\mathrm{K}_{2} \mathrm{O}$ andesites of Blatter et al. (2007). At similar silica concentrations, the lavas near Acambay are significantly poorer in Sr (Fig. 9), $\mathrm{Mg}, \mathrm{Ni}, \mathrm{Cr}, \mathrm{Fe}$, and $\mathrm{Ca}$, and richer in $\mathrm{TiO}_{2}$ and $\mathrm{Nb}$ than the wetter series. Moreover, the modern high- $\mathrm{K}_{2} \mathrm{O}$ lavas identified by Blatter et al. $(2001,2007)$ are found closer to the volcanic front.

The high- $\mathrm{K}_{2} \mathrm{O}$ andesites $(\mathrm{Qva})$ are not the fractionation products of the basaltic andesites (Qvb). Fractionation of the minerals observed in these lavas would not change $\mathrm{Rb} / \mathrm{Ba}$ or $\mathrm{Pb} / \mathrm{Ce}$ ratios, which are significantly higher in the andesites. $\mathrm{Ni}, \mathrm{Cr}$, and $\mathrm{Cu}$ concentrations are also too high in the high- $\mathrm{K}_{2} \mathrm{O}$ andesites for them to be related to basaltic andesites by fractional crystallization. Instead, we attribute these characteristics to crustal contamination involving assimilation of granite or mixing with granitic partial melts.

Alluvium covers a large portion of the field area, specifically in the stream valley and areas of agricultural use (Fig. 5). Alluvium described at the El Durazno locality includes clay and sandstones. The clays are dark brown, massive, and slope-formers with $\sim 10 \%$ sand-sized minerals, such as feldspars. Resistant sandstones interbedded with the clays are light brown to brown, massive, and medium- to coarse-grained. Colluvium covers the slopes of volcanic domes, scoria cones, and the Pastores fault scarp (Fig. 5).

Mammal fossils have not been recovered from the Quaternary section in the study area but have been recovered from other Quaternary sediments near Acambay (Antonio Luiz-Perez, oral communication, 2002). These fossils include horse, camel, mammoth, mastodont, antilocaprid, and bison. These fossils have not yet been formally described. All of this fossil material currently resides in a municipal museum of archaeology in Acambay (Antonio Luiz-Perez, director).

\section{STRUCTURE}

The Pastores fault is an east-west trending normal fault that dips between 50 and $70^{\circ}$ to the north and is the southern boundary of the Acambay graben (Suter et al., 1995; Fig. 3). A 150-m escarpment has formed along the Pastores fault at the southeastern part of the field area (Fig. 40). The Pastores fault is covered in the southwestern part of the field area by unfaulted Pleistocene andesitic lava flows and scoria cones (Suter et al., 1995; Figs. 5, 43, and 44). Minor normal faults cut the sedimentary units in the field area, have approximate offsets of 5-20 m, and have trends that are subparallel to the Pastores fault (Figs. 5, 45, and 46). Only the largest of these normal faults has sufficient displacement to be mapped.

\section{DISCUSSION}

\section{Extensional History}

Mesozoic metasedimentary rocks form the pre-Miocene basement of the Acambay graben (Aguirre-Díaz et al., 2000). The development of the Trans-Mexican Volcanic Belt began in the middle to late Miocene, which roughly corresponds with the initiation of intra-arc extension in the central sector of the belt (Nixon et al., 1987; Ferrari et al., 1999; Márquez et al., 1999; García-Palomo et al., 2000, 2002). Arc-parallel extensional faulting began in late Miocene (between 8 and $5 \mathrm{Ma}$ ) in several areas of the Trans-Mexican Volcanic Belt and $\sim 6 \mathrm{Ma}$ in the Acambay graben, based on the Holocene slip rate of Acambay-Tixmadejé fault and its estimated throw (Suter et al., 2001). The Acambay graben has been interpreted as an intra-arc basin of the Mexican Volcanic Belt (Suter et al., 1995; Campos-Enriquez et al., 2000; Suter et al., 2001).

Suter et al. (2001) suggested that the Quaternary extension was the result of "body forces"- the high topography of Trans-Mexican Volcanic Belt. However, because faulting and volcanism migrated from north to south and because the Acambay graben was active before the Trans-Mexican Volcanic Belt formed, it seems more likely that arc-parallel extension is the combined result of slab rollback and enhanced corner flow (Ferrari et al., 2012).

As evidenced by the 19 November 1912, MS = 6.7 Acambay earthquake, active normal faulting in the Acambay graben continues to the present (Suter et al., 2001). Minor normal faults in the study area are also active, as they cut Quaternary alluvium (Fig. 45). These faults are antithetic to the Pastores fault (Fig. 5). The southeastern part of the Acambay graben lacks evidence of faults with orientations that suggest a relationship to NE-SW trending Basin and Range extensional structures, such as those in the western part of the Acambay graben (Suter et al., 1995; Aguirre-Díaz et al., 2000).

\section{History of the Acambay Graben}

\section{Miocene-Early Pliocene Volcanism and Extension}

Silicic to intermediate volcanism characterizes the late Miocene and early Pliocene of the Acambay graben, as evidenced by

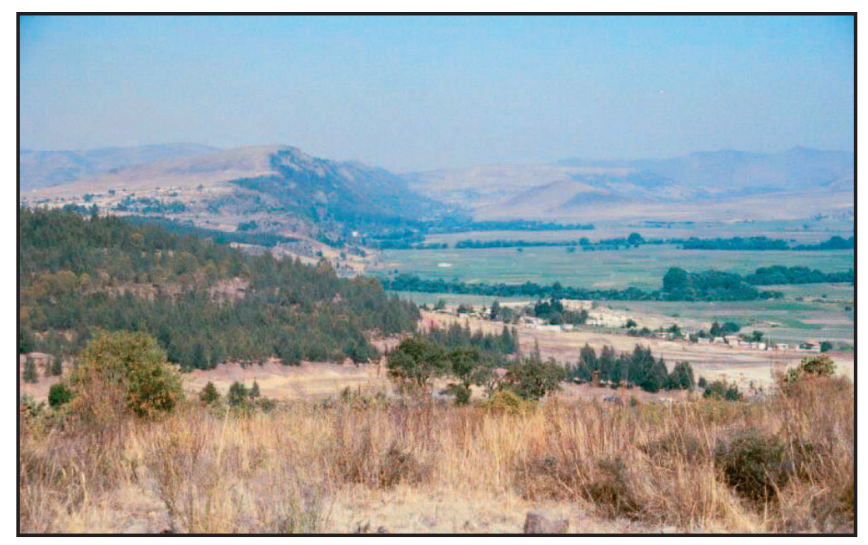

Figure 44. Looking west along the Pastores fault. The photograph was taken from the southwestern part of the field area. The floor of the Acambay graben is the flat farmland. In the foreground, the Pastores fault escarpment is not as prominent as it is farther west (as seen in the background on the left) due to Quaternary andesite lava flows that obscure the fault. 


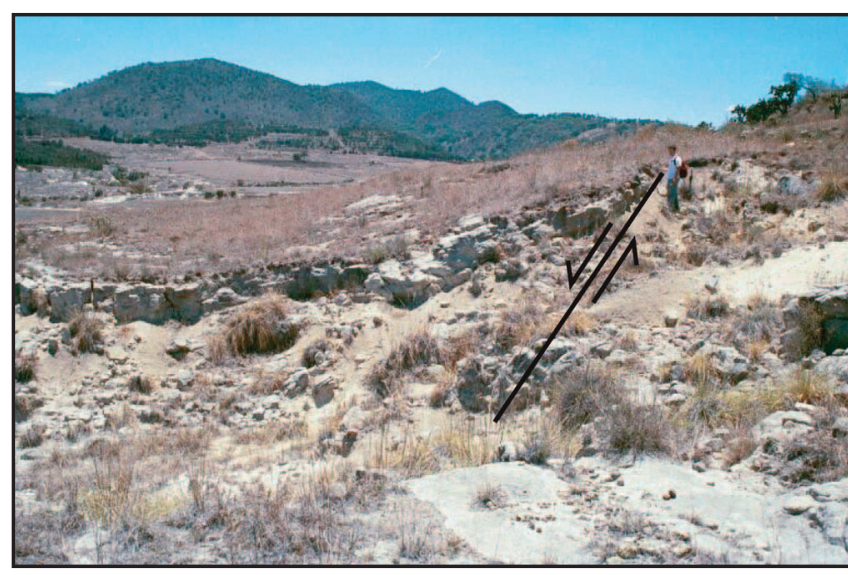

Figure 45. Looking west along an unnamed normal fault mapped in the central part of the field area. The person in the photograph is standing along the plane of the fault, and the Cementerio sandstone bed to the left of the person bends upward near the fault due to fault drag. The eastern flank of the lava dome called Cerro Santa Lucía lies in the background.

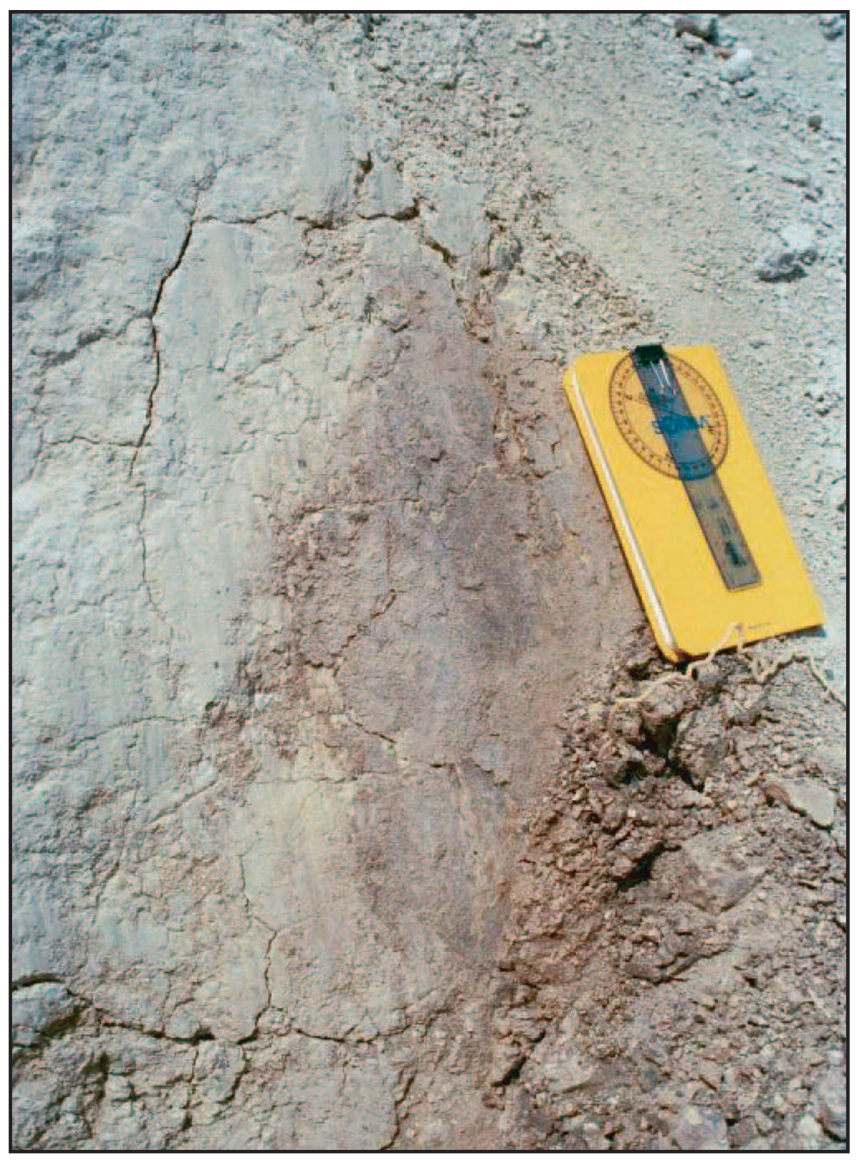

Figure 46. Slickensided surface along the normal fault mapped in the central part of the map area. Faint slickenlines show nearly pure dipslip movement along the fault. The ruler on the notebook is $15 \mathrm{~cm}$ long. The fault is the same as the fault shown in Figure 42, although Figure 42 was photographed near the Línea de Teléfono locality while this photograph was taken in the La Cascada locality (see Fig. 3). the eruption of the Amealco caldera (4.7 Ma; Aguirre-Díaz and McDowell, 2000), the formation of the San Pedro stratovolcano (early Pliocene; Norato-Cortez, 1998), and the occurrence of Miocene-Pliocene volcanic rocks exposed along the flanks of the graben (Aguirre-Díaz et al., 2000). One dacite sample (\#22 on Fig. 5) collected from the footwall of the Pastores fault suggests that late Miocene-early Pliocene volcanism in the Acambay graben had a continental arc affinity (Fig. 8) with an unusual ferroan geochemistry (Fig. 7). Early Pliocene volcanic rocks associated with the Amealco caldera (Aguirre-Díaz and McDowell, 2000) show geochemical similarity to this dacite, including a ferroan geochemical signature.

\section{Pliocene-Pleistocene Sedimentation and Volcanism}

The Pliocene-Pleistocene stratigraphic succession of the southeastern part of the Acambay graben records a period of significant changes in sedimentation and volcanism. Early Pliocene fluvial and alluvial sedimentation, as represented by the Lagunita beds, transitioned to Tierras Blancas lacustrine deposition in the late Pliocene and early Pleistocene (Fig. 47). Fluvial and alluvial sedimentation of the Cementerio beds returned in the Pleistocene and continued to the present.

During the Pliocene and Pleistocene, volcanism continued but resulted in the formation of small volcanic structures, such as silicic lava domes, mafic to intermediate scoria cones, and associated lava flows. The decrease in size of volcanic structures during the Pliocene and Pleistocene corresponds with a trenchward migration in volcanism throughout the Mexican Volcanic Belt.

\section{Early Pliocene Lagunita Sedimentation (Tl)}

Relatively coarse-grained sediment is characteristic of Lagunita deposition. Volcaniclastic sedimentary composition, angular to subangular grains, and gravel beds, as well as fluvial sedimentary structures indicate near-source fluvial and alluvial sedimentation. Local volcanism likely sourced the volcaniclastic sediments and strongly influenced Lagunita deposition, as evidenced by volcanic breccias, pyroclastic fall tuffs, ash-flow tuff, and volcaniclastic sediments. Early Pliocene eruptions from the Amealco caldera and the San Pedro stratovolcano produced volcanic rocks that are the probable sources of Lagunita sediments.

The Pliocene Lagunita tuffs are distal pyroclastic fall deposits and show a marginally peralkaline character that is atypical of continental arc volcanism and generally associated with extensional tectonics (Fig. 6). Peralkaline volcanic centers have been found throughout the Mexican Volcanic Belt (Nixon, 1982; Nixon et al., 1987; Verma, 1987; Moore et al., 1994; Márquez et al., 1999; Sheth et al., 2000). In addition, marginally peralkaline volcanic ashes have been found in Guanajuato, which also lies in the central sector of the Mexican Volcanic Belt (Adams, 2001; Adams et al., 2006). Therefore, it is very plausible for the marginally peralkaline Lagunita tuffs to be eruptive products of peralkaline volcanic centers in distant areas of the Trans-Mexican Volcanic Belt. Based on major and trace element compositions, the fallout tuffs analyzed in the Lagunita beds (and in the Cementerio 


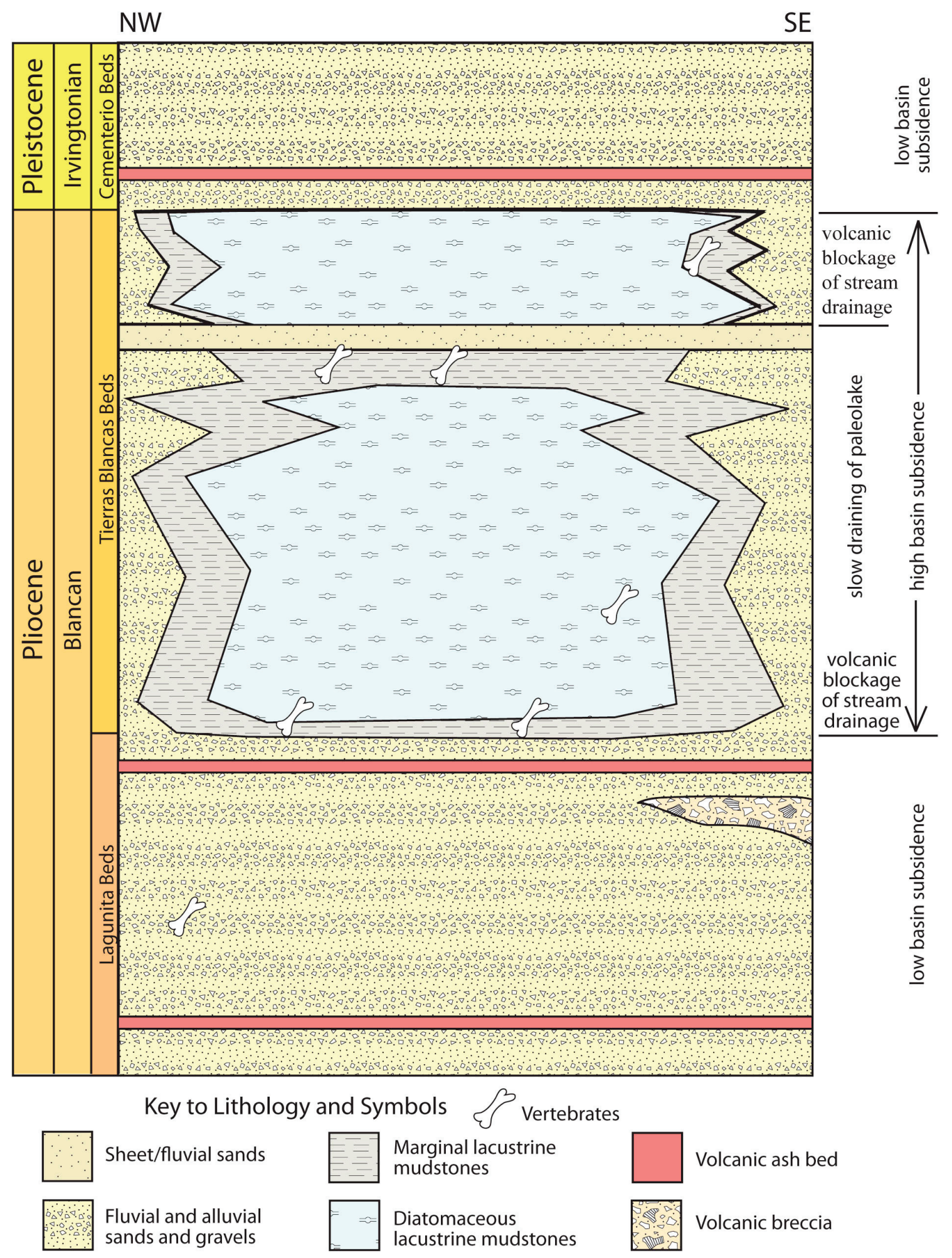

Figure 47. Schematic depositional model of Pliocene-Pleistocene sediments in the southeastern Acambay graben, central Mexico showing interpreted forcing events on the right side of the figure. 
beds) do not correlate with any of the six different late Miocene and Pliocene (5-3 Ma) ash beds we studied in the San Miguel Allende graben near Queretaro (Adams et al., 2006).

Folding of the Lagunita beds does not appear to be directly due to tectonic stress. These folds may, however, have formed indirectly as a result of liquefaction and flow during earthquake events, perhaps in combination with rapid emplacement of volcanic mud, ash, or lava flows. Folding on the same scale (100-m width and 30-m depth) has been observed in the Huckleberry Ridge Tuff in eastern Idaho (Embree, 1999; Embree and Hoggan, 1999). This folding of the Huckleberry Ridge Tuff occurred in response to gravity sliding of the tuff during emplacement on water-saturated, partially-consolidated sediments (Embree, 1999; Embree and Hoggan, 1999).

Even without volcanic or seismic triggering, fault-related folding has been noted in extensional settings (Schlische, 1995) similar to the Acambay graben. The subhorizontal, north-south trending fold axis of the Lagunita fold (Fig. 17) is approximately perpendicular to the Pastores fault as well as a second fault that is antithetic to the Pastores fault and lies within the graben (Fig. 5). Therefore, the Lagunita fold as well as other Lagunita deformation could have formed as transverse folds associated with the Pastores fault and antithetic faults in the graben. Poor understanding of subsurface geology and faults within the Acambay graben and limited exposure of the Lagunita beds creates difficulty in interpreting the possible relationships of transverse folds with the Pastores fault and intragraben faults.

\section{Late Pliocene-Early Pleistocene Tierras Blancas Sedimentation (Ttb)}

Tierras Blancas sedimentation transitioned from Lagunita fluvial and alluvial processes to dominantly lacustrine deposition in the late Pliocene to early Pleistocene (Fig. 47). Relatively finegrained deposits are characteristic of Tierras Blancas sedimentation, as mudstones dominated. The basal sandy mudstone lithofacies corresponds to a period of transition from Lagunita fluvial and alluvial deposition to Tierras Blancas lacustrine sedimentation. Diatomaceous mudstones and massive mudstones dominate the Tierras Blancas stratigraphy and represent periods of relatively deep lacustrine and marginal lacustrine deposition, respectively.

The Tierras Blancas paleolake was likely restricted to a relatively small area $\left(\sim 15 \mathrm{~km}^{2}\right)$, as lacustrine mudstone outcrops are primarily confined to the study area with minor outcrops lying outside the map area by a few kilometers to the west (Fig. 5). Previous studies of Neogene lake systems in the Trans-Mexican Volcanic Belt describe lacustrine sediments similar to the Tierras Blancas beds but have significantly larger geographic areas (Rosas-Elguera and Urrutia-Fucugauchi, 1998; Israde-Alcántara and Garduño-Monroy, 1999; Michaud et al., 2000). Despite its small size, the Tierras Blancas paleolake recorded a detailed history of lacustrine sedimentation highlighted by distinct lake level rises and falls.

The interbedded character of the lacustrine and marginal lacustrine mudstones gives stratigraphic evidence of major lake level fluctuations. Volcaniclastic sandstones interbedded with lacustrine mudstones and changes in the diatom flora (IsradeAlcántara et al., 2010) also demonstrate changes in lake level. The volcaniclastic sandstone has a fluvial character in some areas, as shown by channel-like structures (Fig. 29) and normally graded beds, but generally lack common fluvial sedimentary structures. In either case, the volcaniclastic sandstones would not have been deposited in a lacustrine environment but rather in river/stream system or as large sheet flows into the basin.

A common stratigraphic stacking pattern (Fig. 48) for the mudstones and sandstones is: diatomaceous mudstone (lacustrine), massive mudstone (marginal lacustrine), volcaniclastic sandstone (fluvial/sheet flow), and diatomaceous mudstone (from bottom to top). The gradational contacts between the mudstones indicate relatively gradual changes in lake level at these

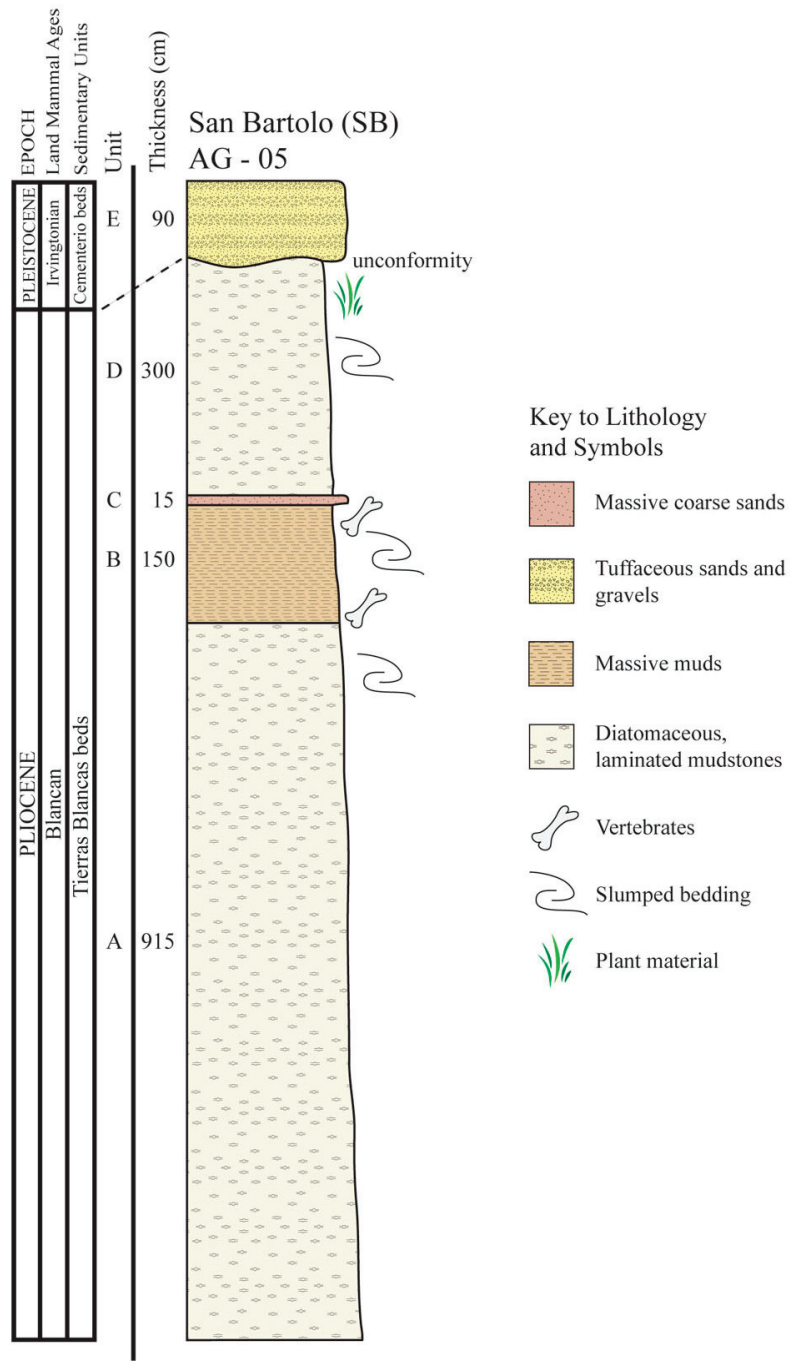

Figure 48. Measured stratigraphic section from the San Bartolo locality (see Fig. 3). The stratigraphic stacking pattern in the Tierras Blancas beds shown here is typical of Tierras Blancas stratigraphy throughout the study area. 
Mercer et al.

boundaries (Fig. 28). Erosion marks the contacts between sandstones and mudstones, as shown by the sharp irregular contacts (Fig. 29). Tool marks on the upper surface of volcaniclastic sandstones suggest erosion followed by a rapid transition to lacustrine deposition, which corresponds with an abrupt rise in lake level (Fig. 31). These stratigraphic patterns indicate gradual lake level falls and rapid lake level rises.

Vertebrate burrows also indicate lake level fluctuations because the burrows were likely excavated by small terrestrial rodents (Stephen Hasiotis, oral communication, 2002; Figures 23-26) during periods of very low lake level or temporary disappearance of the lake. A gradual trend of increased vertebrate burrows and plant material upsection in the lacustrine mudstones suggests a shallowing trend of the lake throughout its history.

As mentioned previously, the volcanic setting of the Tierras Blancas paleolake favored diatom development. Due to the sensitivity of diatoms to physical and chemical environmental conditions, diatom analysis enables the determination of paleolake conditions (Israde-Alcántara and Garduño-Monroy, 1999; Bradbury, 2000; Michaud et al., 2000). The dominance of planktonic genera (Aulacoseira and Stephanodiscus) in the diatomaceous mudstones (Fig. 26) indicates the paleolake remained a relatively deep, freshwater body through most of its history (Israde-Alcántara and Garduño-Monroy, 1999; Bradbury, 2000; Michaud et al., 2000). The ratios of planktonic to periphytic genera abundance suggest water depths in excess of $10 \mathrm{~m}$ (Barker et al., 1994). Only one sample (AG-03-38) near the base of the lacustrine section gives evidence of relatively low lake level (water depth<10 m; Barker et al., 1994), marked by relatively high abundances of periphytic and tycoplanktonic genera (Cocconeis, Synedra, Rophalodia, Cymbella, and Staurosira) and relatively low abundances of planktonic taxa (Aulacoseira and Stephanodiscus) (Fig. 27).

This diatom assemblage suggests a littoral habitat with high aquatic vegetation because Cocconeis placentula and Synedra ulna require more light penetration than Aulacoseira taxa, and with lake level controlling light penetration, a short period of relatively low lake level must have occurred. Relatively low lake level at a stratigraphic level near the base of the lacustrine section is expected, as lake level could easily fluctuate during filling and initial establishment of the lake.

Diatom analysis indicating a lacustrine history strongly dominated by a relatively stable, perennial lake appears to contradict stratigraphic and sedimentologic evidence of major lake level fluctuations. Actually, the apparent lake level stability represented in the diatom analysis probably reflects a sampling bias, where diatoms were only analyzed from samples of Tierras Blancas diatomaceous mudstones. Both sedimentological and diatom evidence suggest a relatively deep lacustrine depositional environment for the diatomaceous mudstone lithofacies. On the other hand, the diatom record might yield evidence of several periods of relatively low lake level if diatoms were analyzed from Tierras Blancas massive mudstones, which represent marginal lacustrine deposition. Therefore, the Tierras Blancas stratigraphic and sedimentologic record best represents the occurrence of lake level fluctuations, while the analyzed diatom record adds to an understanding of depositional environments and paleolake conditions, specifically during periods of relatively high lake level. In addition, the analyzed diatom record demonstrates the stability of high lake level periods, which are then slowly modified by gradual lake level falls.

Soft sediment and bed deformation in the Tierras Blancas beds records another important aspect of early Pleistocene sedimentation in the study area. The relationship of Tierras Blancas deformation with overlying Quaternary lava flows points to emplacement of lava flows on overburdened, water-saturated, partially-consolidated sediments as the cause of deformation. This type of deformation is similar to Lagunita deformation, noted above, although Lagunita deformation is relatively systematic and more extensive. The nonsystematic character of Tierras Blancas deformation indicates slumping occurred in areas where Quaternary lava flowed over Tierras Blancas sediment on an erosional surface with paleotopographic relief. Mixing of a Quaternary andesite with underlying diatomaceous mudstone in at least two locations lends further support to Quaternary lava flows causing Tierras Blancas deformation (Figs. 32 and 33). In addition, deformation is generally confined to the upper part of the Tierras Blancas section, and deformation is not present where Quaternary lava flows do not overlie the Tierras Blancas beds. Oriented forces (i.e., faults producing folding) likely did not produce Tierras Blancas bed deformation because deformed bedding orientations lack a systematic pattern (Fig. 17). However, although these sediments were likely saturated with water when the lava flows occurred, evidence was not found in the study area (pillow lavas, hyaloclastites, etc.) to indicate the presence of standing water.

Based on its dominantly mudstone with sparse sandstone lithologies, the Tierras Blancas strata are a fluvial-lacustrine facies association that fit the overfilled lake basin type of Carroll and Bohacs (1999; Fig. 49). Carroll and Bohacs (1999) suggested that tectonic basin subsidence and/or uplift of drainage barriers allow for potential accommodation to produce lake development and associated deposits (Fig. 49). In addition, climate controls the supply of sediment and water to a basin and, therefore, strongly affects lake occurrence and character (Fig. 49).

In the Pliocene Acambay graben three factors likely affected lake development and fluctuations in lake level over time: extensional tectonism, volcanism, and climate change. Tectonic subsidence, during formation of the graben, created accommodation space for lake development. Variations over time in fault slip rates would affect basin subsidence and could, in turn, lead to a change from lacustrine to fluvial sedimentation (Carroll and Bohacs, 1999). The effect of extensional tectonism has been cited as a major control on lake distribution and evolution in other areas of the Trans-Mexican Volcanic Belt, including Cuitzeo basin (Israde-Alcántara and Garduño-Monroy, 1999) and along the Jalisco triple junction (Rosas-Elguera and Urrutia-Fucugauchi, 1998; Michaud et al., 2000). 
In a paleoseismic study of the Acambay-Tixmadejé fault, Langridge et al. (2000) calculated a Holocene slip rate of $0.17 \mathrm{~mm} / \mathrm{yr}$ based on displacements of sediments exposed in fault trench sites and caused by four late Pleistocene and Holocene ground-rupturing earthquakes. Holocene and Pleistocene sediments in the study area, such as the fluvial and alluvial Cementerio beds, were likely deposited during this period of relatively modest slip rates $(\sim 0.17 \mathrm{~mm} / \mathrm{yr})$, whereas the Tierras Blancas beds may represent a brief period of higher fault slip rates (possibly as high as $0.5 \mathrm{~mm} / \mathrm{yr}$ ) during the late Pliocene, as indicated by lacustrine sedimentation (Fig. 47). The early Pliocene Lagunita beds may have been deposited during a period of lower fault slip rates, perhaps similar to the Holocene, as indicated by their fluvial and alluvial character.

It may be, however that all of the differences in sedimentation are not due solely to extensional tectonics. The formation of drainage barriers, including natural dams produced by lava flow emplacement, also may have created potential accommodation for lacustrine development (Carroll and Bohacs, 1999). This scenario is plausible for the Pliocene Acambay graben given the volcanic arc setting of the graben. In fact, volcanic blockage of stream drainages has aided the formation of various lakes in the Trans-Mexican Volcanic Belt, including modern Lakes Cuitzeo, Pátzcuaro, and Zirahuén (Chacón-Torres and Múzquiz-Iribe, 1997). The strong influence of volcanism on Tierras Blancas deposition is evidenced by lacustrine mudstones that are dominated by diatomite but include layers rich in ashy material, which

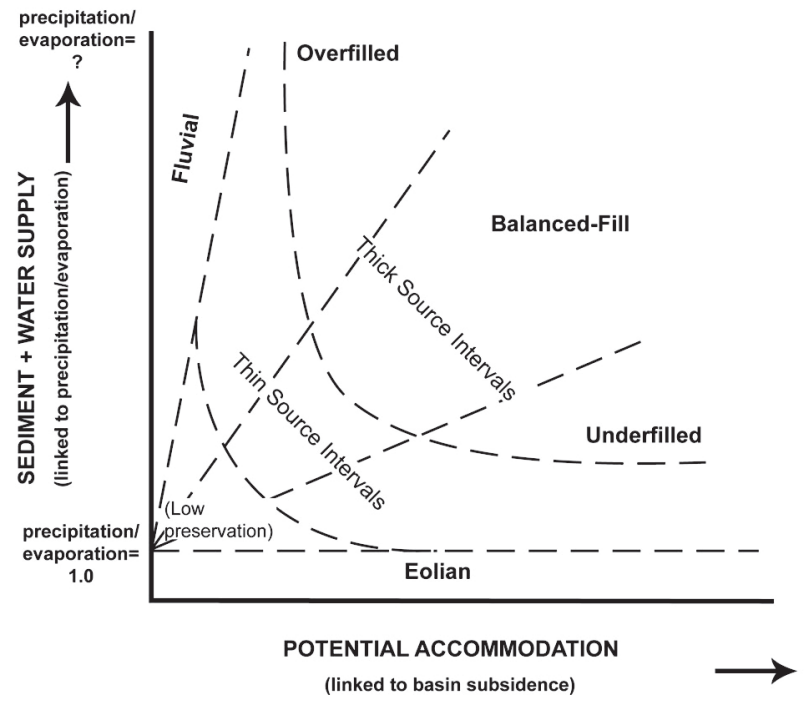

Figure 49. Schematic lake-basin type diagram showing existence and character of nonmarine strata in general and lacustrine strata in particular as a function of both sediment+water supply and potential accommodation. Potential accommodation is the space available for sediment accumulation below the basin's outlet or spillpoint, and it is mainly influenced by basin tectonics and drainage barriers. Sediment+water supply is primarily a function of climatic humidity, along with seasonality, local relief, and bedrock geology. Modified after Bohacs et al. (2000). likely represent pulses of volcanic activity. In addition, the volcaniclastic sandstones of the Tierras Blancas beds are immature and were deposited near their volcanic source rocks. Therefore, sandstone deposition during Tierras Blancas sedimentation was closely related to local volcanism.

The relationship of thin volcaniclastic sandstones to local volcanic events points to some influence of volcanic forcing as a cause of lake level fluctuation. Volcanic forcing could also explain the pattern of rapid lake level rises and gradual lake level falls during Tierras Blancas sedimentation. Upon emplacement of a lava flow acting as a natural dam, lake level rise would be relatively rapid (Fig. 47). Erosion of the natural dam would occur over a longer period of time, allowing for a gradual fall in lake level. Deposition of volcaniclastic sand corresponds to the lowest lake level (or temporary lake disappearance), which is followed by the emplacement of another damming lava flow and subsequent resurgence of the lake. An overall shallowing trend of the lake, evidenced by increased abundance of vertebrate burrows and plant material in the upper Tierras Blancas beds, also suggests volcanic barriers as the cause of lake development because gradual shallowing could correspond to slow erosion of a natural dam. The final disappearance of the lake may have occurred as volcanism ceased to disrupt stream drainages.

Assuming late Pliocene stream drainage patterns in the southeastern Acambay graben were similar to those of the present, lava flow dams would have been located along the southern margin of the graben because present-day streams drain to the southwest (Fig. 5) toward the Lerma River. These lava flows likely were associated with volcanism along the southern and western flanks of the San Pedro stratovolcano, including the Cerro Santa Lucía. It is difficult to determine the exact location of these lava flow dams due to erosion.

The last factor that likely affected lake levels is regional climate (Fig. 49). In fact, the role of climate has been evaluated in the development of many Pleistocene lakes in the TransMexican Volcanic Belt, including Lake Chapala (Clements, 1962; Tereshchenko et al., 2002) and Lake Pátzcuaro (Bradbury, 2000). The overfilled lake-basin model suggests that the Tierras Blancas paleolake was hydrologically open and water inflows from fluvial systems were relatively high (Carroll and Bohacs, 1999; Bohacs et al., 2000). Climatic forcing of lake level in overfilled lake basins is minimal due to open hydrology (Carroll and Bohacs, 1999; Bohacs et al., 2000). Therefore, the role of climate in the establishment of the Tierras Blancas paleolake was likely secondary to those of basin subsidence and volcanic drainage barriers (see Fig. 47).

The diatom record gives some evidence of the role that climate may have contributed. Both Aulacoseira ambigua and Aulacoseira granulata, which are abundant in the Tierras Blancas diatomaceous mudstones, need abundant silica fluxes and tolerate well-mixed, turbid waters (Gasse, 1986). Therefore, Aulacoseira taxa indicate flooding episodes and marginally higher lake levels (Bradbury, 2000). Planktonic taxa, such as Aulacoseira and Stephanodiscus, dominate the diatom assemblage (Fig. 
27), suggesting relatively high precipitation (Bradbury, 2000). A. ambigua and A. granulata bloom in spring and early summer presently in Lake Pátzcuaro and likely followed similar bloom cycles during the Pliocene (Bradbury, 2000). Stephanodiscus taxa bloom in fall and winter after the rainy season delivers increased phosphorus to the lake because high phosphorus levels and reduced insolation (e.g., low light conditions) favor Stephanodiscus development (Bradbury, 2000).

These diatoms overall suggest that the Tierras Blancas time period had slightly higher precipitation and higher humidity than present-day conditions in central Mexico. In addition, the Tierras Blancas lacustrine sediments do not contain evaporite deposits and yield few periphytic and tycoplanktonic diatoms, which indicates a lack of saline conditions during the existence of the Tierras Blancas paleolake. Unfortunately, the diatom flora of the Tierras Blancas beds did not yield any information about possible temperatures of the paleolake.

\section{Late Pliocene-Pleistocene Silicic and Intermediate Volcanism (Tr and Ta)}

Following the deposition of the Tierras Blancas beds, eruption of silicic (dacites and rhyolites of the Cerro Santa Lucía) and intermediate (undated andesite lava flow) volcanic rocks occurred during the late Pliocene and Pleistocene in the southeastern part of the Acambay graben. These volcanic rocks mark a period of voluminous medium- to high- $\mathrm{K}$, magnesian volcanism (Fig. 7) with continental arc affinity (Fig. 8).

\section{Pleistocene Cementerio Sedimentation (Qao)}

After late Pliocene-early Pleistocene lacustrine deposition, sedimentation returned to fluvial and alluvial deposition in the Pleistocene, as represented by the sandstones and mudstones of the Cementerio beds (Fig. 47).

Volcanism continued to play a major role in sedimentation in Pleistocene time. Tuffaceous sandstones in the Cementerio beds consist of reworked volcanic ash and contain detrital vitric volcanic lithic grains from multiple sources. The two samples from the basal Cementerio sandstone (AG-03-01 and AG-06-01) lie in the stratigraphic interval that includes the Cementerio volcanic ash bed (samples MX-2000-06, AG-2002-04, and AG-2002-08). XRF analyses of the glass fractions of the Cementerio tuff correlate well with electron microprobe analyses of vitric volcanic lithic grains from the basal tuffaceous sandstone bed (Figs. 7, 15, and 40). The similarity in glass compositions of the basal tuffaceous sandstone and the tuff indicates the vitric volcanic lithic grains in the sandstone were wholly derived from the Cementerio tuff. The Cementerio tuff and basal tuffaceous sandstones have a high-K, ferroan geochemical signature (Fig. 7) but have other geochemical signatures that correspond with normal continental arc rocks (Fig. 8).

Samples (AG-08-01 and AG-04-04) from upper tuffaceous sandstones of the Cementerio beds show broad ranges of volcanic lithic grain compositions (Figs. 7 and 40), suggesting derivation of grains from multiple sources. A lack of volcanic lithic grains of basaltic andesite composition provides evidence that the basaltic andesite lava flows are younger than the Cementerio beds. The upper Cementerio sands have a mixed geochemical signature with medium- to high-K, ferroan to magnesian grains (Fig. 7). The lithic clasts in AG-08-01 are dominantly magnesian medium- $\mathrm{K}_{2} \mathrm{O}$ andesites, dacites, and rhyolites and may have had local sources like the lavas related to San PedroCerro Santa Lucia volcanic complex. In contrast, the clasts in AG-04-04 are ferroan, high $\mathrm{K}_{2} \mathrm{O}$ latites, trachydacites, and rhyolites (Fig. 40). These clasts must have more distal sources and are similar to the ferroan high $\mathrm{K}_{2} \mathrm{O}$ volcanic series from the Amealco caldera.

\section{Quaternary Volcanism and Sedimentation (Qvb and Qva)}

During the Pleistocene, mafic to intermediate volcanic rocks erupted in the southeastern Acambay graben. The high- $\mathrm{TiO}_{2}$ basaltic andesites $(\mathrm{Qvb})$ erupted from several vents, as indicated by multiple scoria cones (Figs. 5 and 41), but have a close association shown by a consistently tight geochemical grouping (Figs. 7 and 15). Like the basaltic andesites, high- $\mathrm{K}_{2} \mathrm{O}$ andesite lava flows (Qva) show a tight geochemical grouping (Figs. 7 and 15) indicating an eruptive association, despite multiple scoria cones acting as vents (Figs. 5 and 43).

As a result of the abundance of lava flows, Quaternary alluvium and colluvium contain relatively high percentages of volcanic mineral and lithic grains. They represent continued fluvial and alluvial sedimentation throughout the Pleistocene and to the present in the Acambay graben.

Blatter et al. (2007) identified a few lavas that are very similar to the high- $\mathrm{K}_{2} \mathrm{O}$ andesites near Acambay and suggested that they are the result of crustal contamination of the high- $\mathrm{TiO}_{2}$ basaltic andesite. Petrographically, these andesites have abundant quartz xenocrysts and they carry crustal xenoliths composed of granitic rocks. The continental crust in this part of Mexico is significantly thicker than in other regions-reaching over $50 \mathrm{~km}$ thick (Ferrari et al., 2012) and may afford greater chance for contamination. We find this a compelling argument and have tested the notion geochemically. Simple mixing of high- $\mathrm{TiO}_{2}$ basaltic andesite and high- $\mathrm{K}_{2} \mathrm{O}$ rhyolite (taken to represent a silicic partial melt of the underlying crust) produces many of the distinctive characteristics of the high- $\mathrm{K}_{2} \mathrm{O}$ andesites (Qva), including their high $\mathrm{Rb} / \mathrm{Ba}$ ratio, low $\mathrm{Sr}$ and high $\mathrm{Ba}$ (Fig. 50). The model shown is a $60 \%$ basaltic andesite (sample CERRITO) and $40 \%$ rhyolite (sample AG-2002-04). The andesites also lie on linear mixing trends between the basaltic andesite and rhyolite for a wide variety of compatible and incompatible elements; the poorest matches are with $\mathrm{Cr}, \mathrm{Cu}$, and $\mathrm{Zr}$. However, small variations in the composition of the crustal component could account for these differences. Mixing explains several of the otherwise unusual features of the high- $\mathrm{K}_{2} \mathrm{O}$ andesites (Qva), including their high concentrations of compatible elements, as well as their high $\mathrm{TiO}_{2}$ and $\mathrm{Nb}$, high $\mathrm{K}, \mathrm{Rb}, \mathrm{Ba}$, and $\mathrm{Rb} / \mathrm{Ba}$, and low $\mathrm{Sr}$ and $\mathrm{Al}_{2} \mathrm{O}_{3}$. Based on magnetotelluric anomalies (Jödicke et al., 2006) and enhanced seismic attenuation (Chen and Clayton, 2009), the lower crust 
in this region is partially molten. If true, crustal contamination would be almost unavoidable.

\section{Volcanic/Tectonic Synthesis}

The origin of the volcanic rocks of the Acambay area can be fruitfully examined in the light of the tectonic model outlined by Ferrari et al. (2012) for volcanism in central Mexico. They suggest that from 20 to $10 \mathrm{Ma}$ a subducting slab of oceanic lithosphere flattened to a low angle, moving the active arc far inland to the north, and then slowly rolled back to the south to its current position. The Miocene and younger history of Acambay is tied to the roll back stage.

The older Miocene-Pliocene magmas (Tv, Tr, and Ta) near Acambay, probably formed at the contemporary volcanic front (Ferrari et al., 2012) and were produced by dehydration of the subducting oceanic slab followed by flux melting of the overlying mantle wedge (Fig. 51A). These magmas have strong subduction zone signature (medium to high $\mathrm{K}_{2} \mathrm{O}$, high $\mathrm{K} / \mathrm{Ti}, \mathrm{Ba} / \mathrm{Nb}$, low $\mathrm{Zr} / \mathrm{Ba}$, and spikey trace element patterns) and were apparently richer in water. The high Sr concentrations in the older andesites and dacites (CURVA and LOMA) suggest that plagioclase may not have fractionated abundantly in wetter magma. In addition, the older andesite to dacite series was typically oxidized as shown by its magnesian character. As the kink in the subducting slab rolled back to the south, the volcanic front migrated out of the Acambay region.

The origin of the younger magmas can also be placed in this scenario of slab roll back and hinges on the development of the high $\mathrm{TiO}_{2}$ basaltic andesites (Qvb). The Acambay region is currently $100-150 \mathrm{~km}$ behind the volcanic front, which poses special problems for the origin of the Quaternary volcanic rocks. Márquez et al. (1999) proposed that the high- $\mathrm{TiO}_{2}$ magmas are formed in the detached head of a mantle plume beneath central Mexico. This hypothesis does not account for the clear correlation of magmatism with a subducting slab of oceanic lithosphere. Near the trench, the slab is subducting at a shallow angle $\left(\sim 10^{\circ}\right)$ until it reaches $\sim 75 \mathrm{~km}$ from the trench, where slab dip increases

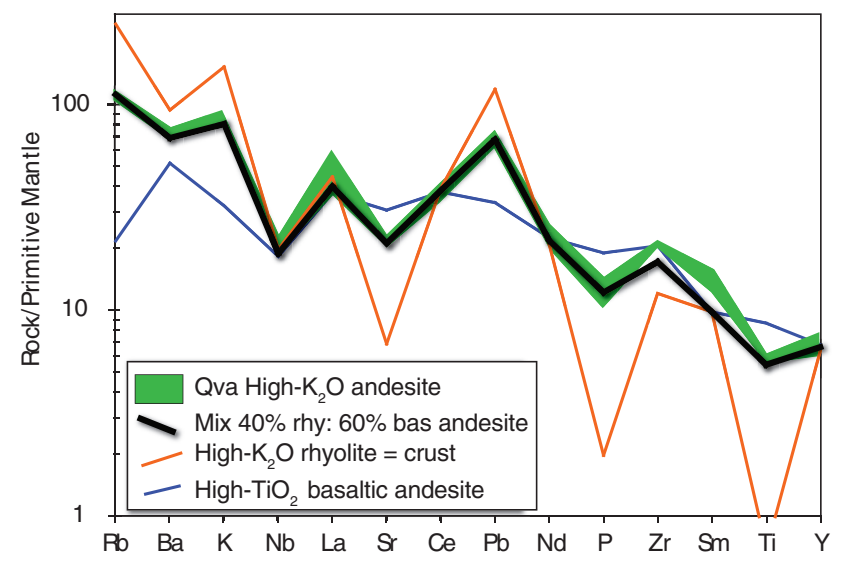

to $\sim 30^{\circ}$ (Manea et al., 2005; Manea and Manea, 2011). North of this, the slab appears to be approximately horizontal between $125-200 \mathrm{~km}$ from the trench and then the slab angle increases again at the volcanic front. According to this model, the slab is $>250 \mathrm{~km}$ deep beneath Acambay today (Ferrari et al., 2012). (The configuration must have been essentially the same when the young Quaternary flows erupted (Fig. 51); the southward migration rate of the volcanic front is only $7.5 \mathrm{~mm} / \mathrm{y}$ (Ferrari et al., 2012) and thus would only have moved $7.5 \mathrm{~km}$ in a million years.) According to Ferrari et al. (2012), dehydration reactions release water from the subducting slab down to $150 \mathrm{~km}$ depth but fluids are concentrated in the $40 \mathrm{~km}$ immediately behind the volcanic front. Therefore, there may be little fluid released from the slab in the zone directly below Acambay. Consequently, it is unlikely that the Quaternary magmas are the result of flux melting of the overlying mantle wedge. Blatter and Hammersley (2010) concluded that the high- $\mathrm{TiO}_{2}$ lavas, with their higher concentrations of high field strength elements and inferred high temperatures and low $\mathrm{H}_{2} \mathrm{O}$ concentrations, formed from "fertile asthenosphere" advected into this region from even farther behind the arc with only small inputs of slab-derived fluid. They proposed that decompression related to extension caused partial melting at greater depths in the mantle (their figure 13, region 3). Blatter et al. (2007) also showed that the high- $\mathrm{TiO}_{2}$ lavas included a larger crustal component than the high- or medium- $\mathrm{K}_{2} \mathrm{O}$ lavas in the region based on their $\mathrm{Nd}-\mathrm{Sr}-\mathrm{Pb}$ isotopic compositions.

We acknowledge the small input of slab-derived components for the high $\mathrm{TiO}_{2}$ basaltic andesites, but call on decompression along the rising limb of a corner flow pattern to induce melting (Fig. 51). Temperatures in the mantle wedge north of the front are estimated to reach $1300{ }^{\circ} \mathrm{C}$ (Ferrari et al., 2012). An alternative, and perhaps less complex, interpretation is that the parents of the high- $\mathrm{TiO}_{2}$ lavas formed by melting of weakly metasomatized (slightly richer in LILE and depleted in high field strength elements), older lithospheric mantle as a result of decompression related to extension (Fig. 51). This hypothesis does not require the introduction of "fertile asthenosphere" from the back-arc and provides an explanation for the slightly lower $\mathrm{e}_{\mathrm{Nd}}$ values and

Figure 50. Calculated trace element pattern for a mixture of a high$\mathrm{TiO}_{2}$ lava $(60 \%)$ and a high-silica rhyolite $(40 \%)$ is a very good match for the high $\mathrm{K}_{2} \mathrm{O}$ andesites of Acambay (Qva). The andesitic lavas also have numerous clots of granitic material indicating they were contaminated by continental crust before eruption. 
the trace element patterns of the high- $\mathrm{TiO}_{2}$ basaltic andesites. In either case, extensive crustal contamination of these magmas produced the young high $\mathrm{K}_{2} \mathrm{O}$ andesites (Qva) as they passed through a crustal partial melt zone.

\section{CONCLUSIONS}

Blancan (Pliocene) mammal fossils recovered in the Acambay graben add to an important collection of late Cenozoic mammal fossils from central Mexico. This collection contributes to an understanding of the Great American Biotic Interchange by constraining the age of the appearance of South American immigrants into North America (Miller and Carranza-Castañeda, 1984, 2001; CarranzaCastañeda and Miller, 1996; Kowallis et al., 1998; Adams, 2001; Flynn et al., 2005; Adams et al., 2006). The development of this basin and preservation of the fossils are tied to the tectonic and climatic evolution of the region as outlined here.

With the fragmentation of the proto-Cocos plate into the present-day Rivera and Cocos plates at $\sim 7 \mathrm{Ma}$ (late Miocene), the modern plate tectonic configuration in central Mexico was established (Nixon, 1982; Verma, 1987; Bandy et al., 2000). Resulting from subduction of these plates beneath the North American plate, continental arc volcanism initiated in the middle to late Miocene with the establishment of the TransMexican Volcanic Belt (Nixon et al., 1987; Márquez et al., 1999; Sheth et al., 2000; García-Palomo et al., 2002; Mori et al., 2007; Ferrari et al., 2012). The migration of the volcanic front has been attributed to slab rollback and the southward migration of the zone of melting above the slab. From the late Miocene-early Pliocene to the early Quaternary, volcanism in

\section{A Mio-Pliocene}

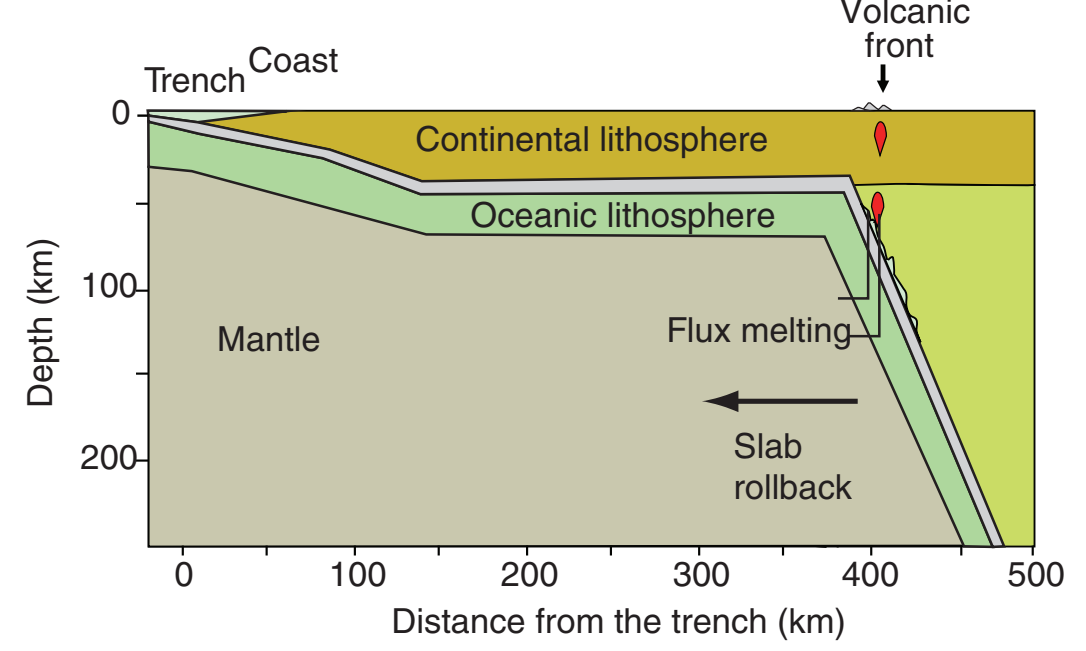

\section{B Quaternary}

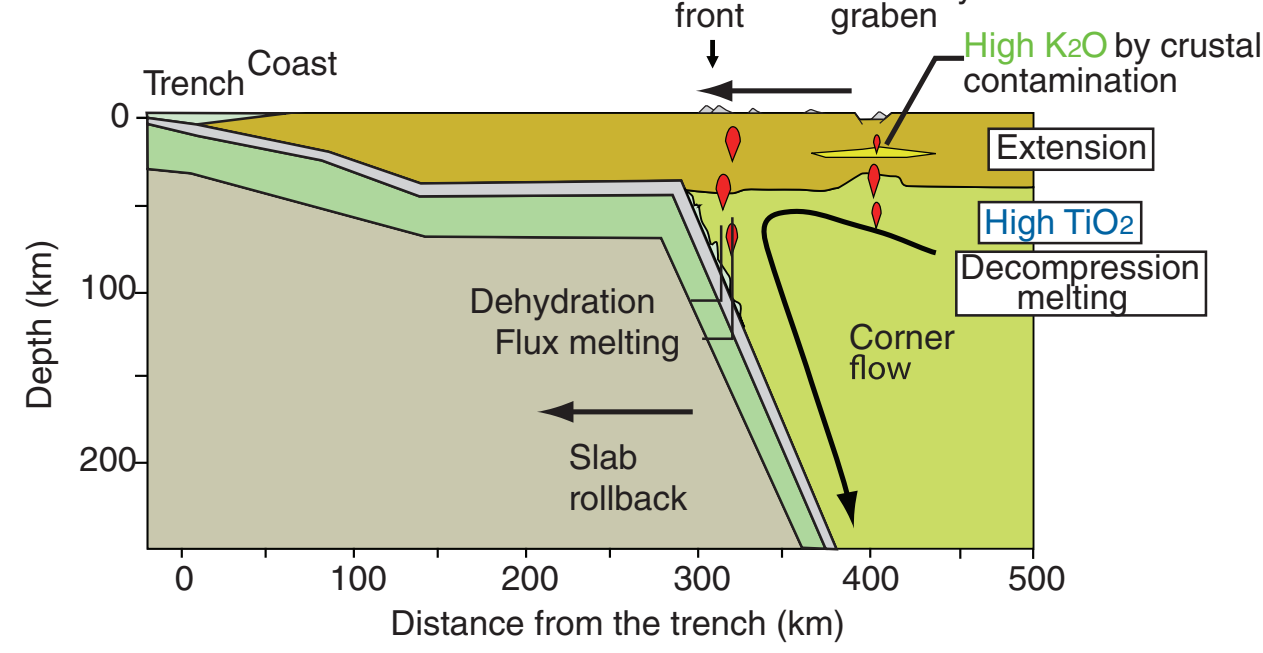

Figure 51. Schematic cross sections, modified from Ferrari et al. (2012) and and Blatter and Hammersley (2010), of central Mexico showing a model for the origin of magmatism in the region near Acambay. (A) During the Late Miocene the volcanic front probably was near Acambay and magmatism was induced by slab dehydration at a shallow depth. This created a medium- $\mathrm{K}_{2} \mathrm{O}$ series of intermediate to silicic magnesian rocks. (B) Slab roll back caused the volcanic front to migrate $\sim 100 \mathrm{~km}$ south to the position of the modern Trans-Mexican Volcanic Belt front. Volcanism in the back arc was driven by extension related to the roll back and the inflow of hot asthenosphere convecting above the slab. Decompression melting created high $\mathrm{TiO}_{2}$ lavas that lack a strong subduction signature and these were extensively contaminated in the crust where a lower crust partial melt zone may exist to form the Quaternary high- $\mathrm{K}_{2} \mathrm{O}$ andesites. 
the Trans-Mexican Volcanic Belt migrated trenchward (Nixon et al., 1987; Ferrari et al., 2012). This southward migration is evident in the region surrounding the Acambay graben because the major eruptive episode in the Acambay graben, which lies on the northern margin of the Trans-Mexican Volcanic Belt occurred during the early Pliocene, highlighted by the eruption of the Amealco caldera (Aguirre-Díaz and McDowell, 2000) and the formation of the San Pedro stratovolcano (NoratoCortez, 1998). Volcanic rocks exposed in the footwall of the Pastores fault erupted during the late Miocene and early Pliocene and coincide with this major eruptive episode in the Acambay graben. Late Pliocene and Pleistocene volcanic structures, such as the Cerro Santa Lucía dacitic dome and intermediate scoria cones, formed in the Acambay graben but are significantly less voluminous than early Pliocene volcanic rocks in the graben. Voluminous Pleistocene volcanism occurred $\sim 100$ $\mathrm{km}$ to the south of the Acambay graben with the development of the Nevado de Toluca stratovolcano (Nixon et al., 1987; GarcíaPalomo et al., 2000, 2002; Bellotti et al., 2006). Volcanism is now concentrated in the modern arc.

Volcanic rocks erupted in the southeastern part of the Acambay graben generally show continental arc affinity and are typical of volcanic rocks in the Trans-Mexican Volcanic Belt (Nixon, 1982; Nixon et al., 1987; Ferrari et al., 2001; Blatter et al., 2001, 2007; ; Blatter and Hammersley, 2010). Miocene-Pliocene calderas and composite volcanoes erupted medium- $\mathrm{K}_{2} \mathrm{O}$ andesites, dacites, and rhyolites ( $\mathrm{Tv}, \mathrm{Ta}, \mathrm{Tr}$ ) derived from flux melting of the mantle wedge above the retreating slab of subducting lithosphere. During the Pleistocene, when the Acambay region lay behind the arc, scoria cones with mixed high $\mathrm{TiO}_{2}(\mathrm{Qvb})$ and high $\mathrm{K}_{2} \mathrm{O}$ (Qva) lavas dominated. We attribute this suite of magmas to back arc convection and decompression melting to form the high $\mathrm{TiO}_{2}$ lavas followed by ponding in the crust and contamination to create the unique group of high $\mathrm{K}_{2} \mathrm{O}$ andesites.

The Lagunita tuffs, on the other hand, have a marginally peralkaline character that is unusual for a continental arc setting. These tuffs are distal pyroclastic fall tuffs that are likely associated with peralkaline volcanic centers that have been found in the Trans-Mexican Volcanic Belt (Nixon et al., 1987; Verma, 1987; Márquez et al., 1999; Sheth et al., 2000). A ferroan geochemical signature, which is also atypical of a continental arc setting, is shown by Miocene-Pliocene volcanic rocks exposed in the footwall of the Pastores fault and is similar to volcanic rocks associated with the Amealco caldera (Aguirre-Díaz and McDowell, 2000). Ferroan geochemistry is also exhibited by volcanic lithic grains from the Pleistocene Cementerio tuff and tuffaceous sandstones. The Cementerio tuff is a distal pyroclastic fall tuff that is likely associated with a distant volcanic center in the TransMexican Volcanic Belt, while the Cementerio tuffaceous sandstones were derived from the volcanic source rocks associated with the Amealco caldera.

Volcanism strongly affected Pliocene-Pleistocene sedimentation, as shown by the dominance of volcaniclastic sediments throughout this time interval, the abundance of diatoms during lacustrine deposition, and variations in sedimentary character influenced by volcanic blockage of stream drainages.

Since the late Miocene and early Pliocene, intra-arc and back-arc tectonics caused the formation of several arc-parallel graben and half-graben structures in the central sector of the Trans-Mexican Volcanic Belt (Suter et al., 1995; CamposEnriquez et al., 2000; Suter et al., 2001). The Acambay graben is one of these intra-arc basins, and extensional faulting in the Acambay graben began $\sim 6 \mathrm{Ma}$ (Suter et al., 2001). Normal faulting continues to the present in the Acambay graben, as shown by large relatively fresh fault escarpments, Quaternary alluvium cut by faulting, and surface rupture of faults in historic time (Suter et al., 1995; Suter et al., 2001).

Development of the Acambay graben allowed for PliocenePleistocene sedimentation in the southeastern portion of the Acambay graben that records an interesting history, including the interruption of alluvial and fluvial deposition by lacustrine sedimentation during the late Pliocene and earliest Pleistocene (Fig. 47). Volcanism and tectonism produced the appearance and disappearance of the late Pliocene Tierras Blancas paleolake through volcanic blockage of stream drainages and increased basin subsidence. Despite the small size $\left(\sim 15 \mathrm{~km}^{2}\right)$ and short history ( $\sim 15 \mathrm{~m}$ thick lacustrine section) of the paleolake, the Tierras Blancas lacustrine sediments record lake level fluctuations, which were also probably produced by volcanic and tectonic forces. Nonetheless, climate played a role in the establishment of the Acambay paleolake, as climatic variations are pervasive in the western hemisphere during late Pliocene-Pleistocene time (Morley and Dworetzky, 1991; Thompson, 1991). In addition, diatom assemblages from the lacustrine sediments indicate a paleoclimate with slightly higher precipitation and humidity than present-day conditions. Due to the open hydrology of the Acambay paleolake, climatic forcing likely played a secondary role to volcanic and tectonic forcing in the appearance and disappearance of the paleolake.

\section{ACKNOWLEDGMENTS}

We thank Dr. Dawnika Blatter for her thoughtful and helpful review of the map and manuscript. The mapping and research were supported in part by National Science Foundation Grant EAR-9902898, with additional support from Brigham Young University and the Universidad Nacional Autónoma de México.

\section{REFERENCES CITED}

Adams, A.J., 2001, Late Cenozoic sedimentation in the San Miguel de Allende Basin, Guanajuato, Mexico [master's thesis]: Provo, Utah, Brigham Young University, $101 \mathrm{p}$.

Adams, A.J., Christiansen, E.H., Kowallis, B.J., Carranza-Castañeda, O., and Miller, W.E., 2006, Contrasting silicic magma series in Miocene-Pliocene ash deposits in the San Miguel de Allende graben, Guanajuato, Mexico: The Journal of Geology, v. 114, p. 247-266, doi:10.1086/499633.

Aguirre-Díaz, G., and López, Martínez M, 2001, The Amazcala caldera, Queretaro, Mexico: Geology and Geochronology: Journal of Volcanology and Geothermal Research, v. 111, p. 203-218. 
Aguirre-Díaz, G.J., and McDowell, F.W., 2000, Volcanic evolution of the Amealco caldera, central Mexico, in Delgado-Granados, H., Aguirre-Díaz, G., and Stock, J.M., eds., Cenozoic Tectonics and Volcanism of Mexico: Boulder, Colorado, Geological Society of America Special Paper 334, p. 179-193.

Aguirre-Díaz, G.J., Urrutia-Fucugauchi, J., Soler-Arechalde, A.M., and McDowell, F.W., 2000, Stratigraphy, K-Ar ages, and magnetostratigraphy of the Acambay graben, central Mexican Volcanic Belt, in DelgadoGranados, H., Aguirre-Díaz, G., and Stock, J.M., eds., Cenozoic Tectonics and Volcanism of Mexico: Boulder, Colorado, Geological Society of America Special Paper 334, p. 167-178.

Bandy, W.L., Hilde, T.W.C., and Yan, C.-Y., 2000, The Rivera-Cocos plate boundary: Implications for Rivera-Cocos relative motion and plate fragmentation, in Delgado-Granados, H., Aguirre-Díaz, G., and Stock, J.M., eds., Cenozoic Tectonics and Volcanism of Mexico: Boulder, Colorado, Geological Society of America Special Paper 334, p. 1-28.

Barker, P.A., Roberts, N., Lamb, H.F., van der Kaars, S., and Benkaddour, A., 1994, Interpretation of Holocene lake-level change from diatom assemblages in Lake Sidi Ali, Middle Atlas, Morocco: Journal of Paleolimnology, v. 12, p. 223-234, doi:10.1007/BF00678022.

Bellotti, F., Capra, L., Groppelli, G., and Norini, G., 2006, Tectonic evolution of the central-eastern sector of Trans Mexican Volcanic Belt and its influence on the eruptive history of the Nevado de Toluca volcano (Mexico): Journal of Volcanology and Geothermal Research, v. 158, p. 21-36, doi:10.1016/j.jvolgeores.2006.04.023.

Blatter, D.L., Carmichael, I.S.E., Deino, A.L., and Renne, P., 2001, Neogene volcanism at the front of the central Mexican Volcanic Belt: basaltic andesites to dacites, with contemporaneous shoshonites and high-TiO2 lavas: Geological Society of America Bulletin, v. 113, p. 1324-1342, doi:10.1130/0016-7606(2001)113<1324:NVATFO>2.0.CO;2.

Blatter, D.L., Farmer, G.L., and Carmichael, I.S.E., 2007, A north-south transect across the central Mexican Volcanic Belt at $\sim 100^{\circ} \mathrm{W}$ : Spatial distribution, petrological, geochemical, and isotopic characteristics of Quaternary volcanism: Journal of Petrology, v. 48, p. 901-950, doi:10.1093/ petrology/egm006.

Blatter, D.L., and Hammersley, L., 2010, Impact of the Orozco Fracture Zone on the central Mexican Volcanic Belt: Journal of Volcanology and Geothermal Research, v, 197, p. 67-84.

Boggs, S., Jr., 1995, Principles of sedimentology and stratigraphy: New Jersey, Prentice Hall, 774 p.

Bohacs, K.M., Carroll, A.R., Neal, J.E., and Mankiewicz, P.J., 2000, Lakebasin type, source potential, and hydrocarbon character: an integrated sequence-stratigraphic geochemical framework, in Gierlowski-Kordesch, E.H., and Kelts, K.R., eds., Lake basins through space and time: Tulsa, Oklahoma, AAPG (American Association of Petroleum Geologists) Studies in Geology 46, p. 3-34.

Bradbury, J.P., 2000, Limnologic history of Lago de Pátzcuaro, Michoacán, Mexico for the past 48,000 years: impacts of climate and man: Palaeogeography, Palaeoclimatology, Palaeoecology, v. 163, p. 69-95, doi:10.1016/S0031-0182(00)00146-2.

Cande, S.C., and Kent, D.V., 1995, Revised calibration of the geomagnetic polarity timescale for the late Cretaceous and Cenozoic: Journal of Geophysical Research, v. 100, no. B2, p. 6093-6095, doi:10.1029/94JB03098.

Campbell, K.E., Jr., Prothero, D.R., Romero-Pittman, L., Hertel, F., and Rivera, N., 2010, Amazonian magnetostratigraphy; dating the first pulse of the Great American Faunal Interchange: Journal of South American Earth Sciences, v. 29, p. 619-626, doi:10.1016/j.jsames.2009.11.007.

Campos-Enriquez, J.O., Rodríguez, M., Delgado-Rodríguez, O., and Milán, M., 2000, Contribution to the tectonics of the northern portion of the central sector of the trans-Mexican Volcanic Belt, in Delgado-Granados, H., Aguirre-Díaz, G., and Stock, J.M., eds., Cenozoic Tectonics and Volcanism of Mexico: Boulder, Colorado, Geological Society of America Special Paper 334, p. 223-235.

Carranza-Castañeda, O., and Miller, W.E., 1988, Roedores caviomorfos de la Mesa Central de México, Blancano temprano (Plioceno tardío) de la fauna local Rancho Viejo, Estado de Guanajuato: Revista Mexicana de Ciencias Geológicas, v. 7, p. 182-199.

Carranza-Castañeda, O., and Miller, W.E., 1996, Hemphillian and Blancan felids from central Mexico: Journal of Paleontology, v. 70, p. 509-518.

Carroll, A.R., and Bohacs, K.M., 1999, Stratigraphic classification of ancient lakes: balancing tectonic and climatic controls: Geology, v. 27, no. 2, p. 99-102, doi:10.1130/0091-7613(1999)027<0099:SCOALB>2.3.CO;2.
Chacón-Torres, A., and Múzquiz-Iribe, E., 1997, Climatic trends, water balance and Lake Pátzcuaro, a tropical high altitude lake: Quaternary International, v. 43, p. 43-51, doi:10.1016/S1040-6182(97)00019-0.

Chen, T., and Clayton, R.W., 2009, Seismic attenuation structure in central Mexico: image of a focused high-attenuation zone in the mantle wedge: Journal of Geophysical Research, v. 114, B07304, doi:10.1029/2008JB005964.

Christiansen, E.H., and McCurry, M., 2008, Contrasting origins of Cenozoic silicic volcanic rocks from the western Cordillera of the United States: Bulletin of Volcanology, v. 70, p. 251-267, doi:10.1007/s00445-007-0138-1.

Clements, T., 1962, Pleistocene history of Lake Chapala, Jalisco, Mexico [abs.]: Geological Society of America Special Paper 68, p. 15.

Coe, A.L., Argles, T.W., Rothery, D.A., and Spicer, R.A., 2010, Geological Field Techniques: Milton Keynes, United Kingdom, The Open University, $323 \mathrm{p}$

Critelli, S., Marsaglia, K.M., and Busby, C.J., 2002, Tectonic history of a Jurassic backarc-basin sequence (the Gran Cañon Formation, Cedros Island, Mexico), based on compositional modes of tuffaceous deposits: Geological Society of America Bulletin, v. 114, no. 5, p. 515-527, doi:10.1130/0016-7606(2002)114<0515:THOAJB >2.0.CO;2.

Dickinson, W.R., 1970, Interpreting detrital modes of graywacke and arkose: Journal of Sedimentary Petrology, v. 40, p. 695-707.

Dickinson, W.R., Beard, L.S., Brakenridge, G.R., Erjavec, J.L., Ferguson, R.C., Inman, K.F., Knepp, R.A., Lindberg, F.A., and Ryberg, P.T., 1983, Provenance of North American Phanerozoic sandstones in relation to tectonic setting: Geological Society of America Bulletin, v. 94, p. 222-235, doi:10.1130/0016-7606(1983)94<222:PONAPS>2.0.CO;2.

Dott, R.H., Jr., 1964, Wacke, graywacke, and matrix — what approach to immature sandstone classification?: Journal of Sedimentary Petrology, v. 34, p. $625-632$.

Embree, G.F., 1999, Secondary deformation within the Huckleberry Ridge Tuff and subjacent Pliocene units near the Teton Dam, northeastern end of the Snake River plain, Idaho: Geological Society of America Abstracts with Programs, v. 31, no. 4, p. 11.

Embree, G.F., and Hoggan, R.D., 1999, Secondary deformation within the Huckleberry Ridge Tuff and subjacent Pliocene units near the Teton Dam; road log to the regional geology of the eastern margin of the Snake River plain, Idaho, in Hughes, S.S., and Thackray, G.D., eds., Guidebook to the geology of eastern Idaho: Pocatello, Idaho, Idaho Museum of Natural History, p. 181-202.

Ferrari, L., López-Martinez, M., Aguirre-Díaz, G., and Carrasco-Núñez, G., 1999, Space-time patterns of Cenozoic arc volcanism in central Mexico: From the Sierra Madre Occidental to the Mexican Volcanic Belt: Geology, v. 27, no. 4, p. 303-306, doi:10.1130/0091-7613(1999)027<0303:STPOCA>2.3.CO;2.

Ferrari, L., Petrone, C.M., and Francalanci, L., 2001, Generation of oceanic-island basalt-type volcanism in the western Trans-Mexican volcanic belt by slab rollback, asthenosphere infiltration, and variable flux melting: Geology, v. 29, no. 6, p. 507-510, doi:10.1130/0091 $-7613(2001) 029<0507:$ GOOIBT $>2.0 . \mathrm{CO} ; 2$

Ferrari, L., Orozco-Esquivel, T., Manea, V., and Manea, M., 2012, The dynamic history of the Trans-Mexican Volcanic Belt and the Mexico subduction zone: Tectonophysics, v. 522-523, p. 122-149, doi:10.1016/j tecto.2011.09.018.

Fisher, R.V., 1961, Proposed classification of volcaniclastic sediments and rocks: Geological Society of America Bulletin, v. 72, p. 1409-1414, doi:10.1130/0016-7606(1961)72[1409:PCOVSA]2.0.CO;2.

Flynn, J.J., Kowallis, B.J., Nuñez, C., Carranza-Castañeda, O., Miller, W.E., Swisher, C.C., III, and Lindsay, E.H., 2005, Geochronology of Hemphillian-Blancan aged strata, Guanajuato, Mexico, and implications for timing of the Great American Biotic Interchange: The Journal of Geology, v. 113, p. 287-307, doi:10.1086/428806.

Frost, B.R., Barnes, C.G., Collins, W.J., Arculus, R.J., Ellis, D.J., and Frost, C.D., 2001, A geochemical classification for granitic rocks: Journal of Petrology, v. 42, no. 11, p. 2033-2048, doi:10.1093/petrology/42.11.2033.

Galbraith, R.F., 1988, Graphical display of estimates having different standard errors: Technometrics, v. 30, p. 271-281, doi:10.1080/00401706.1988.10488400.

Galbraith, R.F., 1990, The radial plot: a graphical assessment of spread in ages: Nuclear Tracks and Radiation Measurements, v. 17, p. 207-214, doi:10.1016/1359-0189(90)90036-W.

García-Palomo, A., Macías, J.L., and Garduño, V.H., 2000, Miocene to Recent structural evolution of the Nevado de Toluca volcano region, Central Mexico: Tectonophysics, v. 318, p. 281-302, doi:10.1016/S0040 -1951(99)00316-9. 
García-Palomo, A., Macías, J.L., Tolson, G., Valdez, G., and Mora, J.C., 2002, Volcanic stratigraphy and geological evolution of the Apan region, eastcentral sector of the Trans-Mexican Volcanic Belt: Geofísica Internacional, v. 41, no. 2, p. $133-150$

Garduño-Monroy, V.H., Pérez-Lopez, R., Israde-Alcántara, I., RodríguezPascua, M.A., Szynkaruk, E., Hernández-Madrigal, V.M., García-Zepeda, M.L., Corona-Chávez, P., Ostroumov, M., Medina-Vega, V.H., GarcíaEstrada, G., Carranza, O., Lopez-Granados, E., and Mora Chaparro, J.C., 2009, Paleoseismology of the southwestern Morelia-Acambay fault system, central Mexico: Geofísica Internacional, v. 48, p. 319-335.

Gasse, F., 1986, East African diatoms. Taxonomy, ecological distribution: Bibliotheca Diatomologica, v. 11, $201 \mathrm{p}$.

Henry, C.D., and Aranda-Gomez, J.J., 1992, The real southern Basin and Range: Mid to late Cenozoic extension in Mexico: Geology, v. 20, p. 701-704, doi:10.1130/0091-7613(1992)020<0701:TRSBAR>2.3.CO;2.

Hurford, A.J., Fitch, F.J., and Clarke, A., 1984, Resolution of the age structure of the detrital zircon populations of two Lower Cretaceous sandstones from the Weald of England by fission track dating: Geological Magazine, v. 121 , p. $269-277$, doi: $10.1017 /$ S0016756800029162.

Ingersoll, R.V., and Cavazza, W., 1991, Reconstruction of Oligo-Miocene volcaniclastic dispersal patterns in north-central New Mexico using sandstone petrofacies, in Fisher, R.V., and Smith, G.A., eds., Sedimentation in volcanic settings: SEPM (Society for Sedimentary Petrology) Special Publication 45, p. 227-236.

Ingersoll, R.V., Bullard, T.F., Ford, R.L., Grimm, J.P., Pickle, J.D., and Sares, S.W., 1984, The effect of grain size on detrital modes: A test of the GazziDickinson point-counting method: Journal of Sedimentary Petrology, v. 54 , p. $103-116$.

Israde-Alcántara, I., 1997, Neogene diatoms of Cuitzeo Lake, central sector of the Trans-Mexican Volcanic Belt and their relationship with the volcanic-tectonic evolution: Quaternary International, v. 43, p. 137-143, doi:10.1016/S1040-6182(97)00029-3.

Israde-Alcántara, I., and Garduño-Monroy, V.H., 1999, Lacustrine record in a volcanic intra-arc setting: the evolution of the Late Neogene Cuitzeo basin system (central western Mexico, Michoacán): Palaeogeography, Palaeoclimatology, Palaeoecology, v. 151, p. 209-227, doi:10.1016/ S0031-0182(99)00024-3.

Israde-Alcántara, I., Miller, W.E., Garduño-Monroy, V.H., Barron, J., and Rodriguez-Pascua, M.A., 2010, Palaeoenvironmental significance of diatom and vertebrate fossils from Late Cenozoic tectonic basins in westcentral Mexico: A review: Quaternary International, v. 219, p. 79-94, doi:10.1016/j.quaint.2010.01.012.

Jödicke, H., Jording, A., Ferrari, L., Arzate, J., Mezger, K., and Rupke, L., 2006, Fluid release from the subducted Cocos plate and partial melting of the crust deduced from magnetotelluric studies in southern Mexico: Implications for the generation of volcanism and subduction dynamics: Journal of Geophysical Research, v. 111, p. B08102, doi:10.1029/2005JB003739.

Johnson, C., and Harrison, C.G.A., 1990, Neotectonics in central Mexico, in Creer, K.M., Urrutia-Fucugauchi, J., and Vilas, J.F., eds., D.A. Valencio Memorial Volume: Physics of the Earth and Planetary Interiors, v. 64, p. $187-210$.

Kowallis, B.J., Heaton, J.S., and Bringhurst, K., 1986, Fission-track dating of volcanically derived sedimentary rocks: Geology, v. 14, p. 19-22, doi:10.1130/0091-7613(1986)14<19:FDOVDS>2.0.CO;2.

Kowallis, B.J., Swisher, C.C., III, Carranza-Castañeda, O., Miller, W.E., and Tingey, D.G., 1998, Fission-track and single-crystal 40Ar/39Ar laserfusion ages from volcanic ash layers in fossil-bearing Pliocene sediments in central Mexico: Revista Mexicana de Ciencias Geológicas, v. 15, p. $157-160$.

Langridge, R.M., Weldon, R.J., II, Moya, J.C., and Suárez, G., 2000, Paleoseismology of the 1912 Acambay earthquake and the Acambay-Tixmadeje fault, Trans-Mexican Volcanic Belt: Journal of Geophysical Research, v. 105, no. B2, p. 3019-3037, doi:10.1029/1999JB900239.

Lindsay, E.H., Opdyke, N.D., and Johnson, N.M., 1984, Blancan-Hemphillian land mammal ages and late Cenozoic mammal dispersal events: Annual Review of Earth and Planetary Sciences, v. 12, p. 445-488, doi:10.1146/ annurev.ea.12.050184.002305.

Lindsay, E.H., Mou, Y., Downs, W., Pederson, J., Kelly, T.S., Henry, C., and Trexler, J., 2002, Recognition of the Hemphillian/Blancan boundary in Nevada: Journal of Vertebrate Paleontology, v. 22, p. 429-442, doi:10.1671/0272-4634(2002)022[0429:ROTHBB]2.0.CO;2.
Manea, V., and Manea, M., 2011, Flat-slab thermal structure and evolution beneath central Mexico: Pure and Applied Geophysics, v. 168, p. 14751487, doi:10.1007/s00024-010-0207-9.

Manea, V.C., Manea, M., Kostoglodov, V., and Sewell, G., 2005, Thermomechanical model of the mantle wedge in central Mexican subduction zone and a blob tracing approach for the magma transport: Physics of the Earth and Planetary Interiors, v. 149, p. 165-186, doi:10.1016/j .pepi.2004.08.024

Márquez, A., Oyarzun, R., Doblas, M., and Verma, S.P., 1999, Alkalic (oceanisland basalt type) and calc-alkalic volcanism in the Mexican Volcanic Belt: A case for plume-related magmatism and propagating rifting at an active margin?: Geology, v. 27, no. 1, p. 51-54, doi:10.1130/0091 -7613(1999)027<0051:AOIBTA >2.3.CO;2.

McDonough, W.F., and Sun, S.-s., 1995, The composition of the Earth: Chemical Geology, v. 120, p. 223-253, doi:10.1016/0009-2541(94)00140-4.

Mercer, L.M., Kowallis, B.J., Carranza-Castañeda, O., Miller, W.E., and Rojas, M.L., 2002, Geology of the southeastern Acambay graben, central Mexican Volcanic Belt: Geological Society of America Abstracts with Programs, v. 34 , no. 6 , p. 282

Metcalfe, S.E., 1997, Palaeolimnological records of climate change in Mexico-frustrating past, promising future?: Quaternary International, v. 43, p. 111-116, doi:10.1016/S1040-6182(97)00026-8.

Michaud, F., Gasse, F., Bourgois, J., and Quintero, O., 2000, Tectonic controls on lake distribution in the Jalisco block area (western Mexico) from Pliocene to present, in Delgado-Granados, H., Aguirre-Díaz, G., and Stock, J.M., eds., Cenozoic Tectonics and Volcanism of Mexico: Boulder, Colorado, Geological Society of America Special Paper 334 p. $99-110$.

Miller, W.E., 1980, The late Pliocene Las Tunas local fauna from southernmost Baja California, Mexico: Journal of Paleontology, v. 54, p. 762-805.

Miller, W.E., and Carranza-Castañeda, O., 1982, New lagomorphs from the Pliocene of central Mexico: Journal of Vertebrate Paleontology, v. 2, p. 95-107, doi:10.1080/02724634.1982.10011920.

Miller, W.E., and Carranza-Castañeda, O., 1984, Late Cenozoic mammals from central Mexico: Journal of Vertebrate Paleontology, v. 4, p. 216-236, doi: 10.1080/02724634.1984.10012005.

Miller, W.E., and Carranza-Castañeda, O., 1996, Agriotherium schneideri from the Hemphillian of central Mexico: Journal of Mammalogy, v. 77, p. 568577, doi: $10.2307 / 1382830$.

Miller, W.E., and Carranza-Castañeda, O., 2001, Late Cenozoic mammals from the basins of Central Mexico: Bollettino della Società Paleontologica Italiana, v. 40, no. 2, p. 235-242.

Montellano-Ballesteros, M., 1992, Una edad del Irvingtoniano al Rancholabreano para la fauna Cedazo del estado de Aguascalientes: Revista Mexicana de Ciencias Geológicas, v. 9, p. 195-203.

Moore, G.M., Carmichael, I.S.E., Marone, C., and Renne, P.R., 1994, Basaltic volcanism and extension near the intersection of the Sierra Madre volcanic province and the Mexican volcanic belt: Geological Society of America Bulletin, v. 106, p. 383-394, doi:10.1130/0016 -7606(1994)106<0383:BVAENT>2.3.CO;2.

Mori, L., Gómez-Tuena, A., Cai, Y., and Goldstein, S.L., 2007, Effects of prolonged flat subduction on the Miocene magmatic record of the central Trans-Mexican Volcanic Belt: Chemical Geology, v. 244, p. 452-473, doi:10.1016/j.chemgeo.2007.07.002.

Morley, J.J., and Dworetzky, B.A., 1991, Evolving Pliocene-Pleistocene climate - a North Pacific perspective: Quaternary Science Reviews, v. 10, p. 225-237, doi:10.1016/0277-3791(91)90021-L.

Nelson, S. A., and Hegre, J., 1990, Volcan Las Navajas, a Pliocene-Pleistocene trachyte/peralkaline rhyolite volcano in the northwestern Mexican Volcanic Belt: Bulletin of Volcanology, v. 52, p. 186-204.

Nixon, G.T., 1982, The relationship between Quaternary volcanism in central Mexico and the seismicity and structure of subducted ocean lithosphere: Geological Society of America Bulletin, v. 93, p. 514-523, doi:10.1130/0016-7606(1982)93<514:TRBQVI>2.0.CO;2.

Nixon, G.T., Demant, A., Armstrong, R.L., and Harakal, J.E., 1987, K-Ar and geologic data bearing on the age and evolution of the Trans-Mexican Volcanic Belt: Geofísica Internacional, v. 26-1, p. 109-158.

Norato-Cortez, T.A., 1998, Estudio estratigráphico-volcanológico-estructural de los volcanes San Pedro y Altamirano (estados de México y Michoacán) y su relación con la evolución tectónica del sector central del Cinturón Volcánico Mexicano [master's thesis]: Linares, Nuevo León, Universidad Autónoma de Nuevo León, 73 p. 
Pearce, J.A., Harris, N.B.W., and Tindle, A.G., 1984, Trace element discrimination diagrams for the tectonic interpretation of granitic rocks: Journal of Petrology, v. 25, p. 956-983, doi:10.1093/petrology/25.4.956.

Perkins, M.E., Nash, W.P., Brown, F.H., and Fleck, R.J., 1995, Fallout tuffs of Trapper Creek, Idaho; a record of Miocene explosive volcanism in the Snake River plain volcanic province: Geological Society of America Bulletin, v. 107, p. 1484-1506, doi:10.1130/0016-7606(1995)107<1484 :FTOTCI $>2.3 . \mathrm{CO} ; 2$.

Ponomarenko, A.L., 2004, The Pachuca Obsidian Source, Hidalgo, Mexico: A geoarchaeological perspective: Geoarchaeology: An International Journal, v. 19, p. 71-91.

Ramírez-Herrera, M.T., 1998, Geomorphic assessment of active tectonics in the Acambay graben, Mexican Volcanic Belt: Earth Surface Processes and Landforms, v. 23, p. 317-332, doi:10.1002/(SICI)1096 -9837(199804)23:4<317::AID-ESP845>3.0.CO;2-V.

Rosas-Elguera, J., and Urrutia-Fucugauchi, J., 1998, Tectonic control of the volcanosedimentary sequence of the Chapala graben, western Mexico: International Geology Review, v. 40, p. 350-362, doi:10.1080/00206819809465214.

Sánchez-Rubio, G., 1984, Cenozoic volcanism in the Toluca-Amealco region, central Mexico [master's thesis]: London, Imperial College of Science and Technology, University of London, $275 \mathrm{p}$

Scherer, R.P., 1994, A new method for the determination of absolute abundance of diatoms and other silt-sized sedimentary particles: Journal of Paleolimnology, v. 12, p. 171-179, doi:10.1007/BF00678093.

Schlische, R.W., 1995, Geometry and origin of fault-related folds in extensional settings: The American Association of Petroleum Geologists Bulletin, v. 79 , no. 11 , p. 1661-1678.

Sheth, H.C., Torres-Alvarado, I.S., and Verma, S.P., 2000, Beyond subduction and plumes: A unified tectonic-petrogenetic model for the Mexican Volcanic Belt: International Geology Review, v. 42, p. 1116-1132, doi:10.1080/00206810009465129.
Suter, M., Quintero-Legorreta, O., López-Martínez, M., Aguirre-Díaz, G.J., and Farrar, E., 1995, The Acambay graben: Active intra-arc extension in the trans-Mexican volcanic belt, Mexico: Tectonics, v. 14, p. 1245-1262, doi:10.1029/95TC01930.

Suter, M., López-Martínez, M., Quintero-Legorreta, O., and Carrillo-Martínez, M., 2001, Quaternary intra-arc extension in the central Trans-Mexican volcanic belt: Geological Society of America Bulletin, v. 113, no. 6, p. 693-703, doi:10.1130/0016-7606(2001)113<0693:QIAEIT>2.0.CO;2

Tereshchenko, I., Filonov, A., Gallegos, A., Monzon, C., and Rodriguez, R., 2002, El Nino 1997-98 and the hydrometeorological variability of Chapala, a shallow tropical lake in Mexico: Journal of Hydrology (Amsterdam), v. 264, p. 133-146, doi:10.1016/S0022-1694(02)00066-5.

Thompson, R.S., 1991, Pliocene environments and climates in the western United States: Quaternary Science Reviews, v. 10, p. 115-132, doi:10.1016/0277-3791(91)90013-K.

Verma, S.P., 1987, Mexican Volcanic Belt: Present state of knowledge and unsolved problems: Geofísica Internacional, v. 26-2, p. 309-340.

Webb, S.D., 1991, Ecogeography and the great American interchange: Paleobiology, v. 17, p. 266-280.

Webb, S.D., and Opdyke, N.D., 1995, Global climatic influence on Cenozoic land mammal faunas, in Kennett, J.P., and Stanley, S.M., eds., Effects of Past Global Change on Life: Washington, D.C., National Academy of Sciences, p. 184-208.

Wetzel, A., 2013, Tilting marks; observations on tool marks resembling trace fossils and their morphological varieties: Sedimentary Geology, v. 288, p. 60-65, doi:10.1016/j.sedgeo.2013.01.003.

Woodburne, M.O., 2004, Late Cretaceous and Cenozoic Mammals of North America: Biostratigraphy and Geochronology: New York, Columbia University Press, 391 p.

Manuscript AccePted by the Society 25 November 2013 